\title{
Ecology of Bonytail and Razorback Sucker and the Role of Off-Channel Habitats in Their Recovery
}

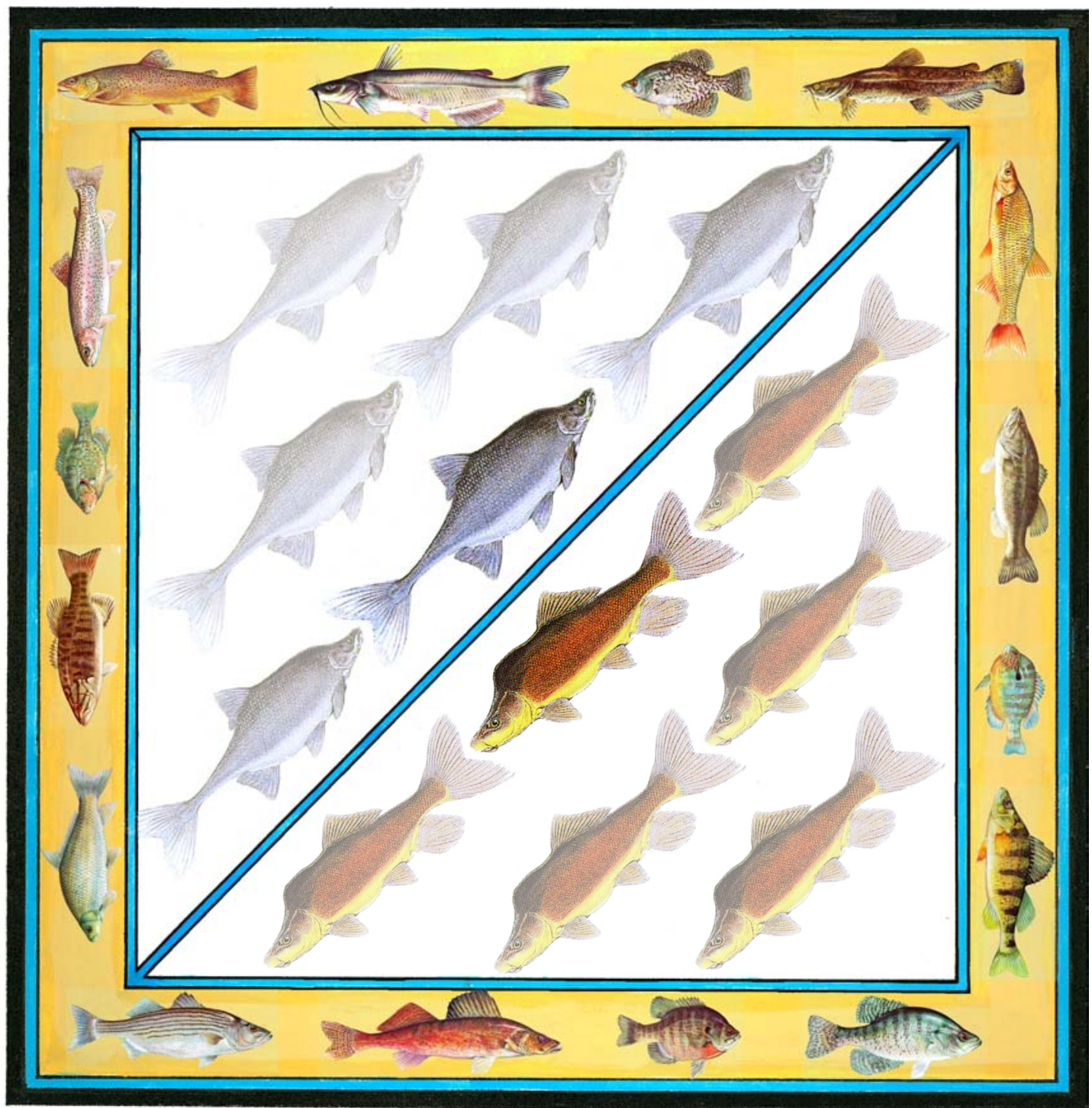

Scientific Investigations Report 2006-5065 


\section{Ecology of Bonytail and Razorback Sucker and the Role of Off-Channel Habitats in Their Recovery}

By Gordon A. Mueller

In cooperation with the U.S. Fish and Wildlife Service, the Bureau of Reclamation, and Arizona State University.

Scientific Investigations Report 2006-5065 


\section{U.S. Department of the Interior \\ P. Lynn Scarlett, Acting Secretary}

\section{U.S. Geological Survey \\ P. Patrick Leahy, Acting Director}

U.S. Geological Survey, Reston, Virginia: 2006

For product and ordering information:

World Wide Web: http://www.usgs.gov/pubprod

Telephone: 1-888-ASK-USGS

For more information on the USGS--the Federal source for science about the Earth, its natural and living resources, natural hazards, and the environment:

World Wide Web: http://www.usgs.gov

Telephone: 1-888-ASK-USGS

Any use of trade, product, or firm names is for descriptive purposes only and does not imply endorsement by the U.S. Government.

Although this report is in the public domain, permission must be secured from the individual copyright owners to reproduce any copyrighted materials contained within this report 


\section{Contents}

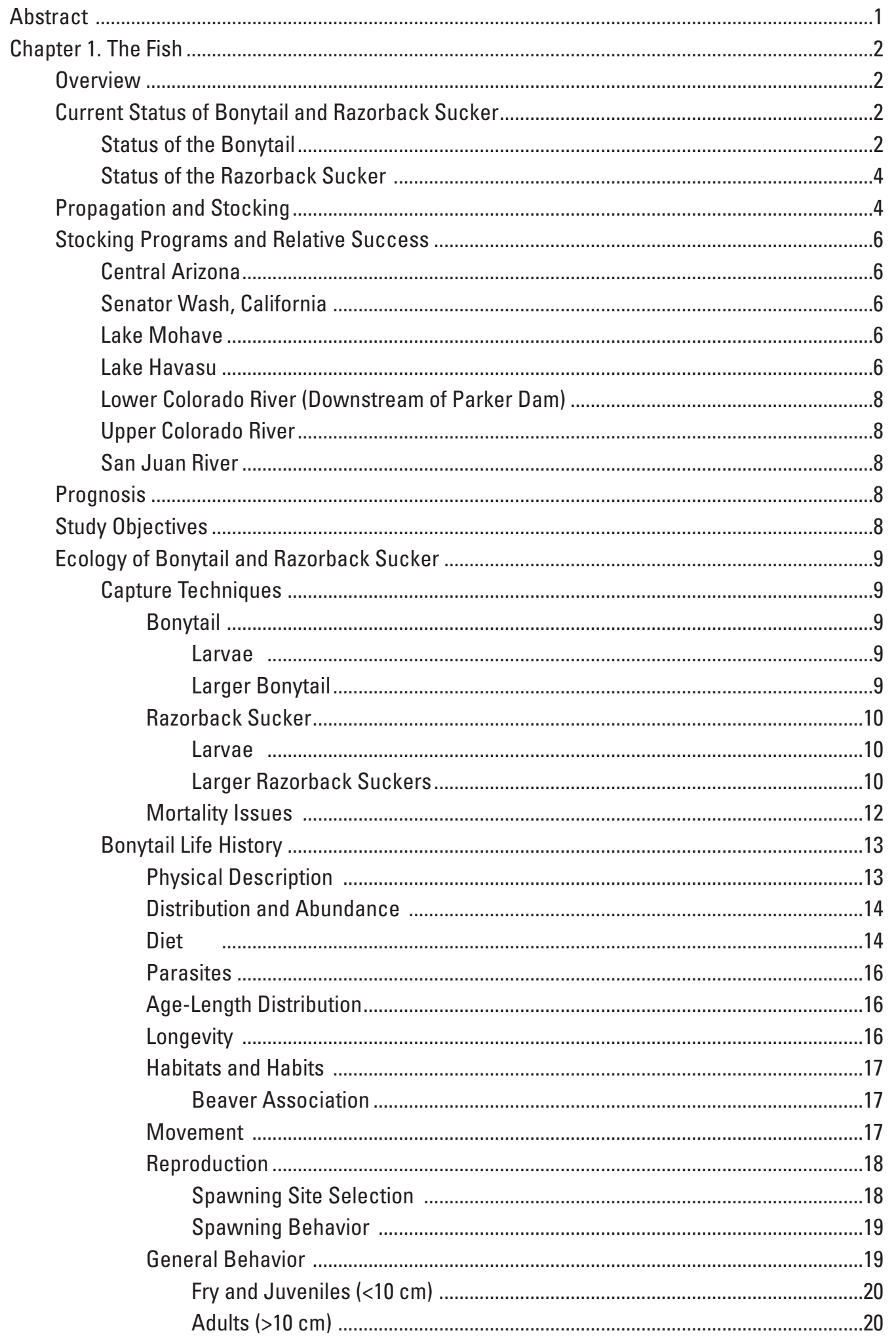




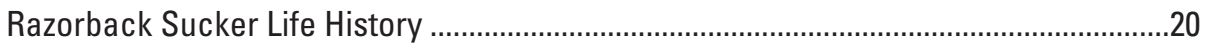

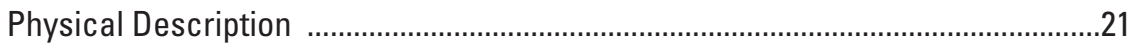

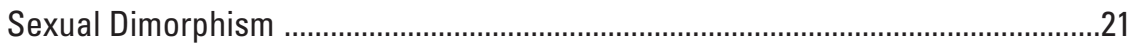

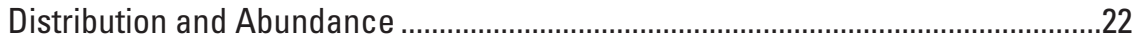

Historic Distribution ......................................................................................22

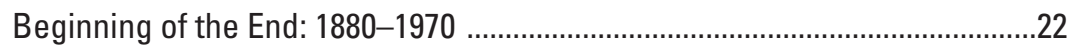

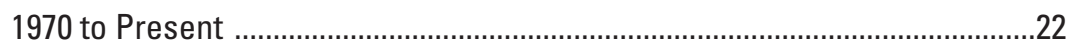

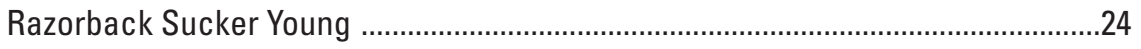

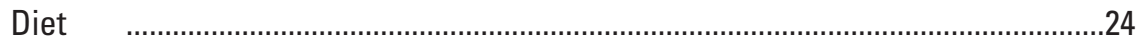

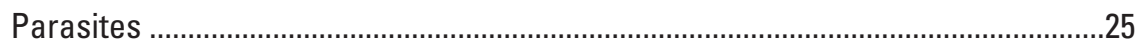

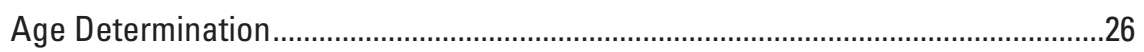

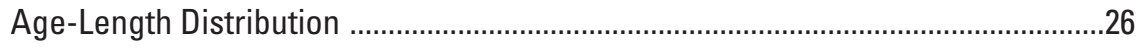

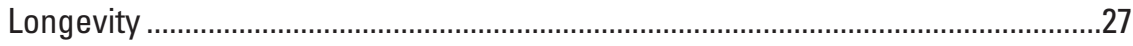

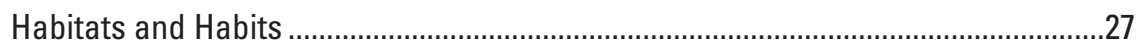

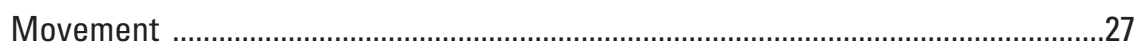

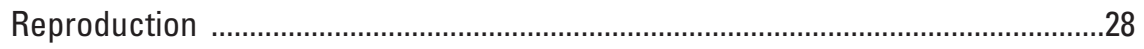

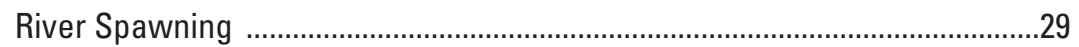

Reservoir/Pond Spawning ........................................................................31

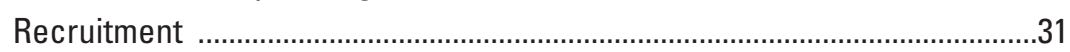

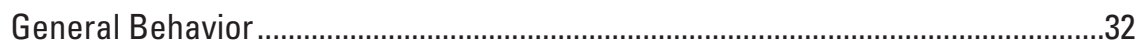

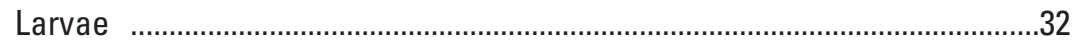

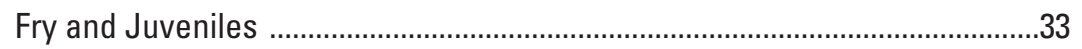

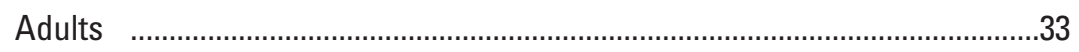

Eye "Blinking" ...........................................................................................33

Chapter 2. Complete Life Cycle of Two Endangered Fishes at Cibola High Levee Pond ................35

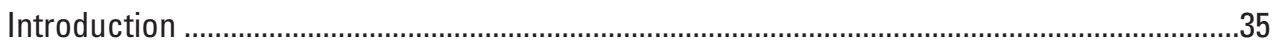

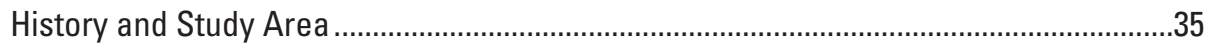

Ecological Importance of Cibola High Levee Pond ........................................................35

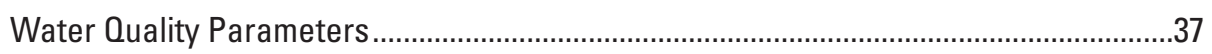

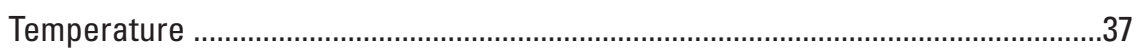

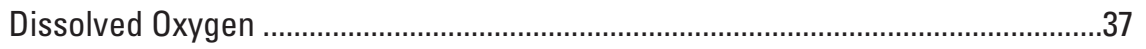

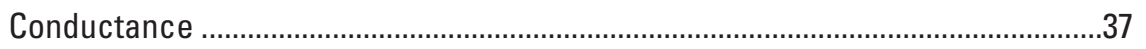

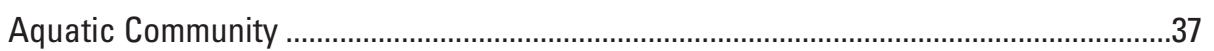

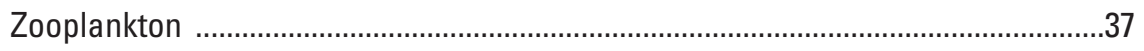

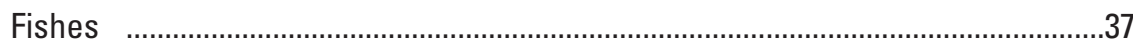

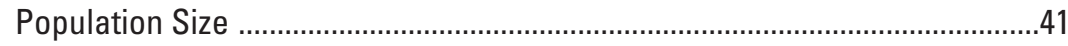

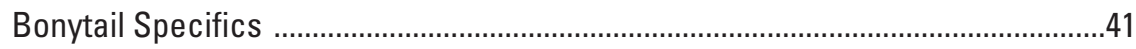

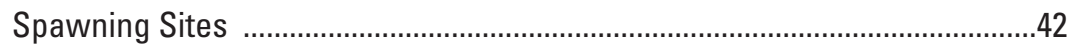

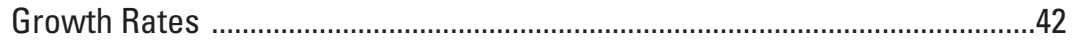

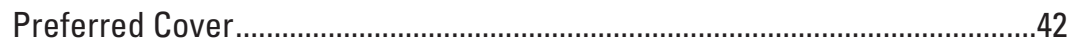

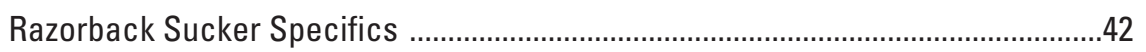

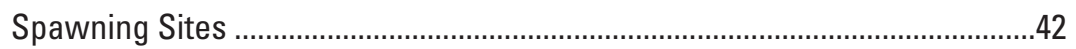

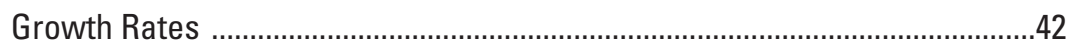

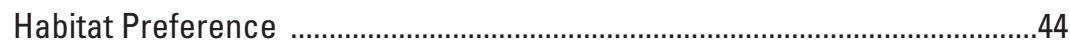

Other Animal Communities ..................................................................................... 
Factors Contributing to Successful Recruitment ...........................................................44

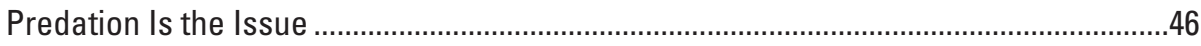

Cibola High Levee Pond Future …………………………………………………....46

Management Plan ............................................................................................... 48

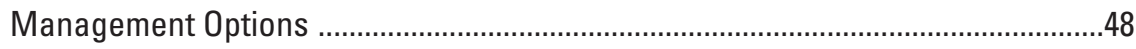

Physical Habitat Improvements ..............................................................................49

Chapter 3. Oxbow Communities: The Missing Key to Recovery? .................................................50

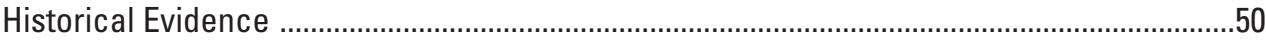

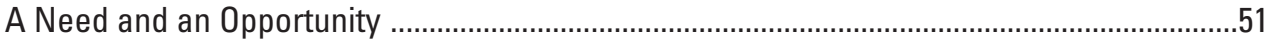

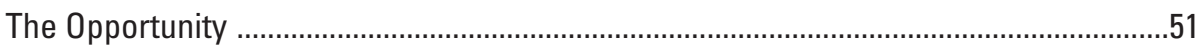

Research and Management Roles …………………....................................................52

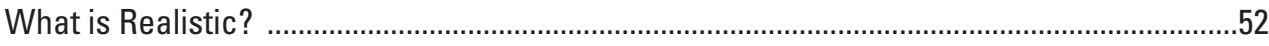

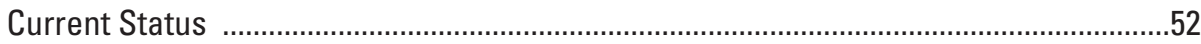

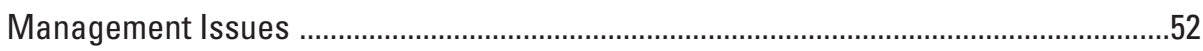

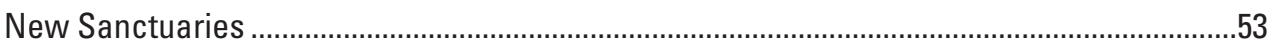

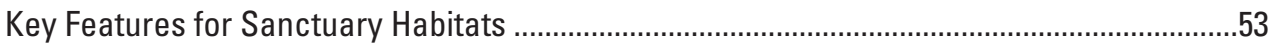

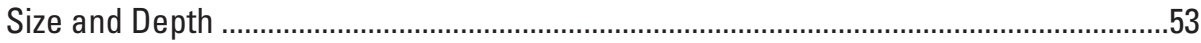

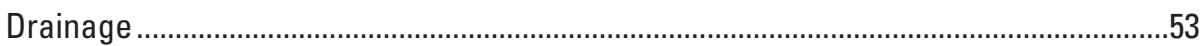

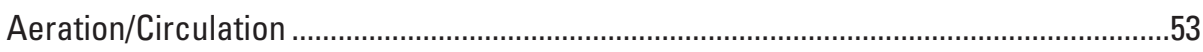

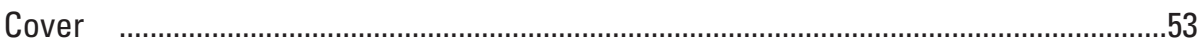

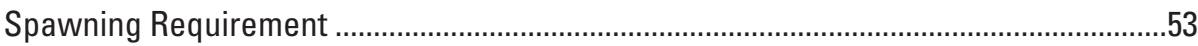

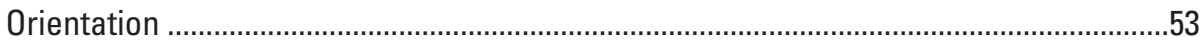

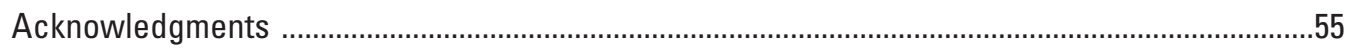

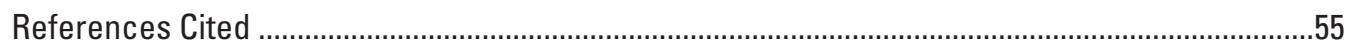

\section{Figures}

1. General map of Colorado River Basin located in the southwestern United States ...................3

2. Aerial photograph of Dexter National Fish Hatchery and Technology Center's rearing ponds located near Dexter, New Mexico ....................................................................................

3. Aerial photograph of Ouray National Fish Hatchery located near Vernal, Utah .......................5

4. Aerial view of Wahweap State Fish Hatchery located near Blue Water, Utah .........................5

5. Aerial view of Willow Beach National Fish hatchery located downstream of Hoover Dam at Willow Beach, Arizona .......................................................................................................

6. Diagram showing the origin of small fish or broodstock for major facilities propagating razorback sucker in the Colorado River Basin ..............................................................

7. Comparison of razorback sucker stocking size compared with actual first year survival ........8

8. Photograph of an ancient rock fish trap located near the Salton Sea, California ......................9

9. Trammel nets are the standard method of capturing bonytail in Lake Mohave .......................10

10. Tom Burke, Bureau of Reclamation, refined hand-collection techniques for razorback sucker larvae.

11. U.S. Geological Survey biologists drain the contents of a floating light trap for future

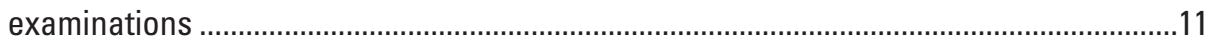

12. Razorback sucker captured from CHLP exhibiting a spinal deformity .....................................12 
13. Captured bonytail that were held for a few days often exhibited discoloration, swelling, stiffness, and subdermal hemorrhaging

14. Hatchery bonytail used in an experiment exhibited body discoloration or banding associated with handling

15. A drawing illustrating the morphology of bonytail larvae .....................................................13

16. A photograph showing an intermediate-sized bonytail .........................................................14

17. Gordon Mueller (U.S. Geological Survey) holding a large $(50 \mathrm{~cm})$, mature bonytail ................14

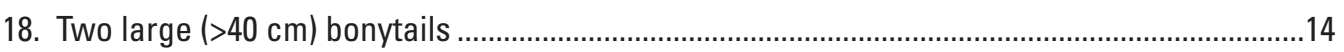

19. Historical and current distribution of bonytail in the Colorado River Basin ..............................15

20. Bonytail stomach contents by 50-mm size class, Cibola High Levee Pond ...............................16

21. Average length $(\mathrm{mm})$ of bonytail growth of known ages at CHLP and Dexter NFHTC ............16

22. A school of small $(>5 \mathrm{~cm})$ bonytail found inside the entrance of a beaver den at Cibola High Levee Pond

23. A small bonytail female freely expressing eggs taken from Cibola High Levee Pond ..............18

24. Ripe male bonytail with sexually pigmented coloration ........................................................18

25. Sexual characteristics of female and male bonytail ...............................................................18

26. Hydrograph for the Colorado River at Yuma, Arizona (1904-1934) .........................................19

27. Bonytail spawning site located on the terminus of a beaver trail on the river levee ...............19

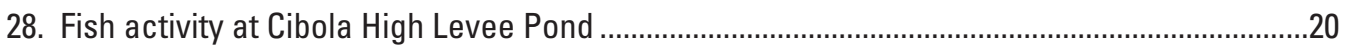

29. Startled bonytail exhibiting a cooperative fright behavior .......................................................

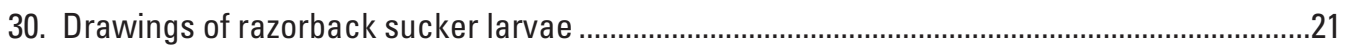

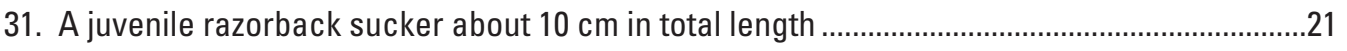

32. C.0. Minckley holding a repatriated razorback sucker ............................................................21

33. Photograph showing the sexual characteristics of a razorback sucker female and male showing differences in size and shape of their genitalia ...............................................22

34. Historic and current range of stocked and wild populations of razorback sucker ...................23

35. The abdominal area of a razorback sucker larvae ............................................................25

36. A school of approximately three dozen adult razorback suckers feeding on zooplankton near the surface of CHLP

37. Quentin Bradwisch (Utah Department of Natural Resources) with a razorback sucker that was captured by trammel net .......................................................................................

38. A high percentage of old razorback suckers were blind in one or both eyes ..............................26

39. Comparison of the average length ( $T L=m m)$ of razorback sucker year classes grown under different rearing conditions

40. A razorback sucker located in the main channel of the Colorado River .....................................27

41. A juvenile razorback sucker hiding its head in aquatic vegetation .......................................28

42. Swelled genital region of a young razorback sucker female showing expelled eggs ..................28

43. Hydrograph for the Colorado River at Yuma, Arizona .............................................................29

44. The last known location (exposed gravel bar between the two islands) where wild razorback sucker spawn in the Green River near Jensen, Utah ...........................................................2

45. A diagram of the Ringbolt Rapids spawning site located downstream of Hoover Dam ...............30

46. A photograph showing where razorback suckers spawned at the Ringbolt Rapids site ............30

47. Repatriated razorback suckers migrate possibly $40 \mathrm{~km}$ or more upstream from Lake Havasu to spawn near Needles, California ................................................................................................30

48. Substrate used by spawning razorback sucker found in the mainstem Colorado River ..............30

49. Thousands of razorback suckers once spawned along the shoreline of the major mainstem reservoirs in the Lower Colorado River. 
50. A group of spawning razorback suckers .....................................................................................

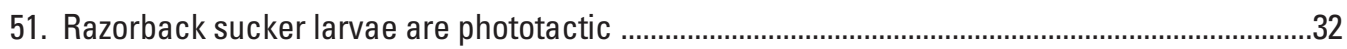

52. Organisms attracted and captured in a light trap ................................................................3

53. Photograph showing a spawning razorback sucker resting on the bottom of Cibola High

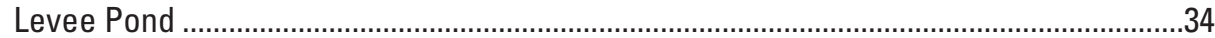

54. A frame grab of the same fish exhibiting the "blinking" phenomenon ....................................34

55. General map of the locaton of Cibola National Wildlife Refuge and Cibola High Levee Pond ....36

56. Cibola High Levee Pond taken from the high levee looking north to the river levee .....................37

57. Bathometry map of Cibola High Levee Pond taken during seasonally high flows ........................38

58. Map showing the composition of bottom material at Cibola High Levee Pond .............................39

59. Aquatic plant growth during the summer dominates much of the pond's volume and area .......40

60. Photograph (taken 15 August 1933) of the Colorado Delta region ....................................................40

61. Mean weekly diel temperature range of surface waters at Cibola High Levee Pond ...................40

62. Surface conductance $(\mu \mathrm{S} / \mathrm{cm})$ taken at Cibola High Levee Pond..................................................40

63. Seasonal winter-through-summer cycle of the major zooplankton groups found in Cibola High

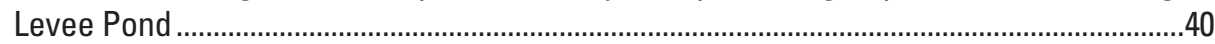

64. Composition of the fish community at Cibola High Levee Pond ...................................................41

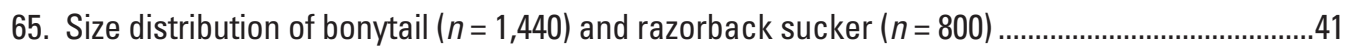

66. Size distribution of all bonytail captured in Cibola High Levee Pond .............................................41

67. Multiple year classes (possibly four) of bonytail captured in Cibola High Levee Pond ................42

68. Map of Cibola High Levee Pond showing the primary and secondary locations where bonytail were observed exhibiting spawning behavior or their eggs were found .............................43

69. Growth rates of bonytail $(n=31)$ taken from Cibola High Levee Pond based on 50-mm size

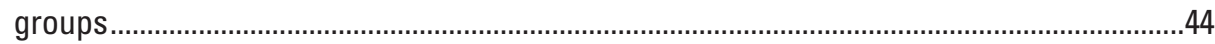

70. The percentage of bonytail females versus males larger than $350 \mathrm{~cm}$ taken from Cibola High

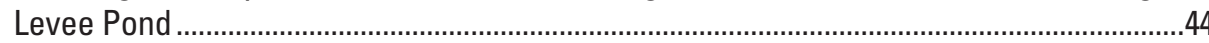

71. Map of Cibola High Levee Pond showing areas of cover used by large $(>30 \mathrm{~cm})$ bonytail and smaller $(<20 \mathrm{~cm})$ bonytail ................................................................................................ 45

72. Size distribution of razorback suckers captured in Cibola High Levee Pond ..................................46

73. Multiple year classes (possibly four) of razorback sucker captured from Cibola High Levee Pond.

74. Map of Cibola High Levee Pond showing the primary and secondary locations where razorback sucker were observed exhibiting spawning behavior ..........................................4

75. Growth rates of razorback suckers $(n=86)$ taken from CHLP based on 25 -mm-size groups .....48

76. The percentage of females versus males for razorback sucker larger than $450 \mathrm{~cm}$....................48

77. Photograph showing the stomach contents of a channel catfish...............................................48

78. Photograph of largemouth bass capture from Cibola High Levee Pond .......................................48

79. A large bonytail taken from Cibola High Levee Pond exhibiting a large healed wound ...............49

80. Yuma Cove is located on Lake Mohave (Arizona-Nevada) ............................................................50

81. Rock Tank is located on the Buenos Aires National Wildlife Refuge in southern Arizona ..........51

82. Landscape illustration (surface, top down) of a native fish sanctuary designed to mimic features found at Cibola High Levee Pond ........................................................................54

83. Landscape illustration (side view) of a native fish sanctuary designed to mimic features found at Cibola High Levee Pond 


\section{Tables}

1. Major propagation facilities for bonytail and/or razorback sucker that are stocked in the Colorado River Basin.

2. Catch rate of bonytail larvae and invertebrate taxa captured in light traps set in Cibola High Levee Pond in 2002

3. Capture rates of minnow traps, hoop nets, box traps, fyke nets, trammel nets, and electrofishing used to capture bonytail at Cibola High Levee Pond from 2001 through 2004.

4. Capture rates of minnow traps, hoop nets, box traps, fyke nets, trammel nets, and electrofishing used to capture razorback sucker at Cibola High Levee Pond from 2001 through 2004

5. Total number of species, number of fish collected, and their composition (\%) from Cibola High Levee Pond from 2001-2005.

6. Population estimates for bonytail and razorback sucker at Cibola High Levee Pond during 2002 


\title{
Ecology of Bonytail and Razorback Sucker and the Role of Off-Channel Habitats in Their Recovery
}

\author{
By Gordon A. Mueller ${ }^{1}$
}

\begin{abstract}
The bonytail and razorback sucker are two of four endangered mainstem fishes found in the Colorado River. Unlike the Colorado pikeminnow and humpback chub, wild populations of the bonytail and razorback sucker are either extirpated from the mainstem river or are nearly so. Agencies are aggressively stocking these fish and while repatriated fish spawn, their young are rapidly eaten by introduced predators. A decade of predator removal efforts has proved ineffective in restoring natural recruitment. Today, the presence of these species is totally dependent on stocking, suggesting both species are worse off today than when recovery efforts began nearly two decades ago.

In contrast, both species readily produce young in ponds where nonnative predators are absent. Evidence shows they evolved with the ability to spawn in both flowing and standing water, which suggests isolated oxbow communities may have been an essential feature in their evolution and survival strategy.

Sustainable populations during the past few decades have only occurred in isolated ponds devoid of predatory nonnative fish. Efforts to force recovery in the main channel river continue to fail due to the presence of nonnative predators that may be economically important recreational species. Off-channel sanctuaries provide research and management opportunities on a scale that are both biologically and economically realistic. Effective management of these species in small habitats appears to be the most logical approach to advance recovery in larger river reaches.

This report presents new findings, updates existing information, and describes what may well represent the only practical approach to these species' conservation and recovery. Chapter 1 provides an overview of the Colorado River system from its origin to the Gulf of California and includes a description of propagation and stocking programs which have not been described elsewhere. The report also updates what is known or suspected on the life history and ecology of these two endangered fishes. Chapter 2 describes the successful recruitment of both species at an oxbow pond on the Cibola National Wildlife Refuge in Arizona, discusses factors that contribute to completion of the life cycle of both fishes, and provides recommendations for future management of the impoundment. Chapter 3 provides historical evidence that oxbow habitats were formed historically in years of high runoff and the importance of these habitats for survival and evolution of native fishes. It also summarizes key features of habitats that can serve as sanctuaries that enhance early survival of the endangered fishes and allow the fish to complete their entire life cycles.
\end{abstract}

Key words: bonytail, isolated habitats, native fish sanctuary, razorback sucker, recruitment. 


\section{Chapter 1. The Fish}

\section{Overview}

Bonytail (Gila elegans) and razorback sucker (Xyrauchen texanus) are part of the Big River Fish Community described by Minckley (1973) and are endemic to the Colorado River in the southwestern United States of America (fig. 1). They evolved in one of the most physically diverse and environmentally harsh river basins in the world. Catastrophic events such as floods and droughts periodically devastated this community (Stanford and Ward, 1986; Douglas and others, 2003). For example, historic flows at Yuma, Arizona, dwindled to as little as $1.4 \mathrm{~m}^{3} / \mathrm{s}$ during droughts and swelled as much as 11,200 $\mathrm{m}^{3} / \mathrm{s}$ during floods (Stanford and Ward, 1986). During peak flooding, the river could be represented as a wall of water 10 $\mathrm{m}$ deep and $1 \mathrm{~km}$ wide. Water temperatures were also extreme, ranging from $0^{\circ} \mathrm{C}$ to $>35^{\circ} \mathrm{C}$ (Mueller and Marsh, 2002). Both species were historically widespread and abundant in mainstem habitats throughout the Colorado River system (Jordan and Evermann, 1896). Their survival depended upon their ability to live and reproduce in an unpredictably harsh environment.

Harsh climatic and riverine conditions are reflected in the reproductive strategies for long-lived species. For example, razorback sucker females have the ability to produce several million eggs during their 50-year lifespan. During adverse conditions such as droughts, recruitment was low, possibly non-existent. Recruitment was not necessarily a yearly occurrence. Their fitness (reproductive success) depended on survival and reproduction of just two young. Needless to say, survival of each young presumably was one chance in several million!

The ability of both species to adapt to the fluctuating conditions is recognized collectively in the scientific literature but is seldom acknowledged in scientific circles. This is due in part to a lack of historical data and the fragmented nature of today's populations caused by the physical and biological alterations to the basin during the past century. Floods and droughts are now regulated through large upstream reservoirs, and floodplain and oxbow habitats, which were once abundant, have been drained and buried under desert farmland and altered by urban development. Recovery of these fish has been further complicated by conflicting uses of the resource, including political agendas, institutional boundaries, and different philosophical approaches (Marsh, 2004a; Clarkson and others, 2005).

These fish were highly adaptive to changing environmental conditions, but their young were extremely vulnerable to introduced predators. Historically, the Colorado pikeminnow (Ptychocheilus lucius) and large Gila spp. were the major piscivores in the Colorado River system. Unfortunately, they have been replaced by several dozen nonnative predators that are aggressive and more numerous than their native predecessors. These fishes benefited from the creation of large storage reservoirs and regulation of stream flows that moderated historic drought and flood conditions in the basin (Mueller and Marsh, 2002). The vast majority of young bonytail and razorback suckers disappeared nearly half a century ago and with them the ability of the Colorado River system to sustain native populations (USFWS, 1984; USFWS, 1998a). Populations declined as surviving fish died of old age and were not replaced by young adults (Minckley and others, 1991). As a result, both species are now listed as endangered under provisions of the Endangered Species Act of 1973.

Human intervention has done little to reverse the loss of native communities. Forty years of research, with nearly 20 years in recovery efforts and 10 years of active nonnative predator control programs, have failed to recover, or even slow, the decline of these species (Minckley and Deacon, 1991; Mueller and Marsh, 2002). Predator removal programs have been ineffective and costly, with targeted species rapidly recolonizing treatment areas (Mueller, 2005). In many areas, the spread of northern pike (Esox lucius), smallmouth bass (Micropterus dolomieui), and other introduced species has only increased (Tyus and Saunders III, 2000; Mueller and Brooks, 2004; USFWS, 2004). Effective control of undesirable nonnative fishes in a large riverine environment is highly unlikely since it requires substantial manpower on a continuous basis and results in only partial removal of such fishes. Fish that remain after control efforts exhibit faster growth and higher fecundity that allows undesirable fishes to be highly resilient to control efforts (Wydoski and Wiley, 1999). Effectiveness of nonnative fish control is compromised by conflicting issues involving recreational fisheries, salvage requirements, trespass issues, and angler sentiments (Marsh, 2004a; Clarkson and others, 2005). The two most important factors in the extinction of 40 native North American fishes (27 species and 13 subspecies) during the past century were habitat alteration and nonnative fish introductions (Miller and others, 1989). These are the same two factors impacting the bonytail and razorback sucker.

Today, wild bonytail are most likely extirpated from the Colorado River mainstem and only a few hundred wild razorback suckers remain. Some of these long-lived fish survive and spawn but natural recruitment does not occur because of predation by nonnative fishes. The presence of these two endangered species is being maintained through propagation and stocking of large fish.

\section{Current Status of Bonytail and Razorback Sucker}

\section{Status of the Bonytail}

Bonytail were federally listed as endangered under the Endangered Species Act of 1973 on 23 April 1980. Wild fish are believed extirpated from the Upper and possibly the entire Colorado River Basin (45 FR 27710). Critical habitat was designated on 4 September 1994 (59 FR 13374). The last 


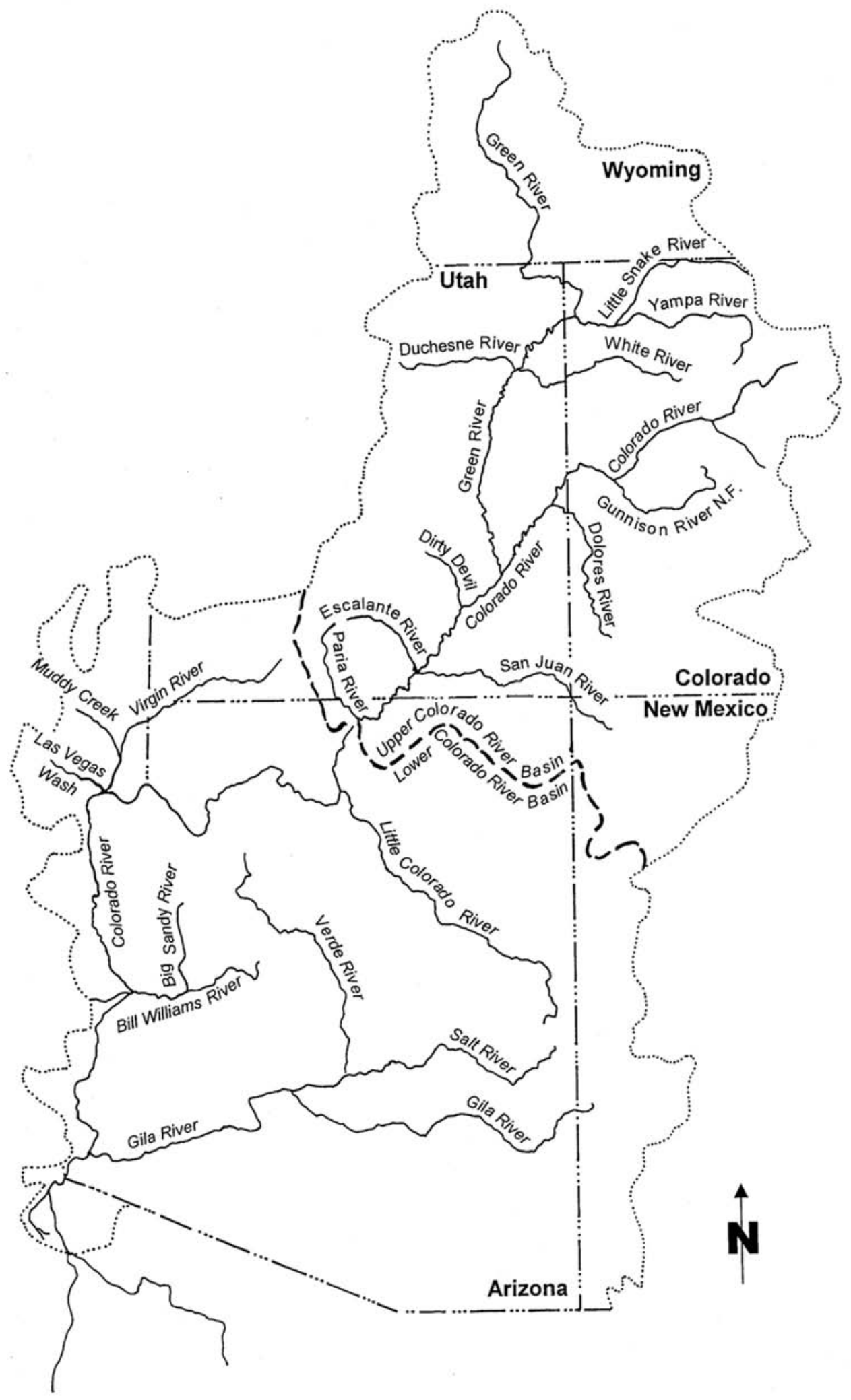

Fig. 1. General map of Colorado River Basin located in the southwestern United States. 
confirmed wild bonytail was taken in the Lower Basin in the mid-1990's, and the last capture in the Upper Basin occurred in 1985 (Valdez and others, BIO-WEST, Inc., written comm., 1994; Marsh, 1997a). Bonytail are being supplemented by stocking with no recruitment in nature reported except volunteer spawn in rearing ponds (Pacey and Marsh, 1998).

\section{Status of the Razorback Sucker}

This fish was federally listed as endangered on 23 October 1991 (56 FR 54957). A final rule designating critical habitat was published on 21 March 1994 (59 FR 13374). Wild fish have been reduced (circa 2005) to about 500 in Lake Mohave, 300 in Lake Mead, <50 in Senator Wash Reservoir (Ulmer and Anderson, 1985), and 100 in the Green River, Utah (Holden and others, 1997; Bestgen and others, 2002; Paul Marsh, Arizona State University [ASU], oral commun., unpublished data, 2004). Wild populations are extirpated from the Salt, Gila, Gunnison, San Juan, and Upper Colorado Rivers and portions of the basin south of the international border (USFWS, 2002b). Relic populations are in rapid decline and are being augmented or reestablished through stocking. Natural sustainable recruitment in the mainstem river has been absent or minimal for several decades.

\section{Propagation and Stocking}

Propagation and stocking are the only actions that have prevented the extirpation of bonytail and razorback sucker from the Colorado River. Initially, literally millions of small fish were stocked. Today, fewer but larger fish are stocked to increase survival (Mueller, 1995; Burdick and others, 1995; Ryden, 1997).

Propagation efforts were started almost too late for bonytail. This species was allowed to become so rare that it nearly became extinct. The existing hatchery stocks can be traced back to possibly three females (Minckley and others, 1989; Hedrick and others, 2000). Potential problems associated with genetic bottlenecks in such a small broodstock have resulted in recommendations to maintain better genetic diversity in hatchery broodstock (Dowling and DeMarais, 1993; Hedrick and others, 2000). Propagation of razorback sucker proceeded with greater caution, resulting in three separate efforts designed to maintain the remaining genetic diversity for that species. These include two locations in the Upper Colorado River Basin and one in the Lower Basin.

Seven facilities are being used to propagate either bonytail, razorback sucker, or both to be stocked into the Colorado River Basin (table 1). Wild bonytail and razorback sucker were first collected from Lake Mohave beginning in 1974 and transported to Willow Beach National Fish Hatchery (WBNFH) (Toney, 1974; Minckley and others, 1991). Dexter National Fish Hatchery and Technology Center (Dexter NFHTC) began operation in 1980, where broodstock were developed for both species (Minckley, 1985) (fig. 2, table 1). Dexter NFHTC maintains the only existing broodstock for bonytail. Stocking in the Lower Colorado River Basin began in 1981 (Johnson, 1985; USFWS, 2002a), and during the past 25 years, Dexter NFHTC alone has produced more than 2.1 million bonytail and 15 million razorback sucker (Dexter NFHTC, unpublished data, 2004). Dexter NFHTC maintains a broodstock of 300 razorback sucker and produces young suckers that are either directly stocked downstream of Davis Dam (USFWS, 1993) or are grown out at other facilities to be stocked elsewhere.

The Upper Basin Recovery Implementation Program (RIP) identified a minimum of three and possibly five unique genetic strains of razorback sucker in the Upper Colorado River (Tom Pitts, Hall Pitts and Assoc., written commun., 1997; Czapla, 1998). There were only sufficient numbers of surviving fish to attempt development of two separate broodstocks of Upper Basin fish: one at Ouray National Fish Hatchery (Ouray NFH) located near Vernal, Utah (fig. 3), and the other at the Grand Valley Facility at Grand Junction, Colorado. The Ouray NFH broodstock was established on the premise that fish surviving in the Green River possessed unique survival characteristics worth preserving (Williamson and Wydoski, 1994). Their broodstock was made up primarily of wild fish taken from the Green River or their progeny. The facility has 36 ponds, isolation tanks, and a hatchery building. Razorback sucker produced there are stocked in the Green River, with surplus fish going toward Grand Valley stocking commitments.

The Grand Valley Facility maintains approximately 300 razorback sucker for broodstock that represent a mixture of fish originating from stock taken from the Green River, fish from the Lower Basin, and a few surviving fish from the Upper Colorado River. Production meets stocking goals for the Gunnison, Colorado, and San Juan Rivers. In addition, there are several facilities in the Upper Colorado River Basin that utilize fish produced from the two facilities. The San Juan

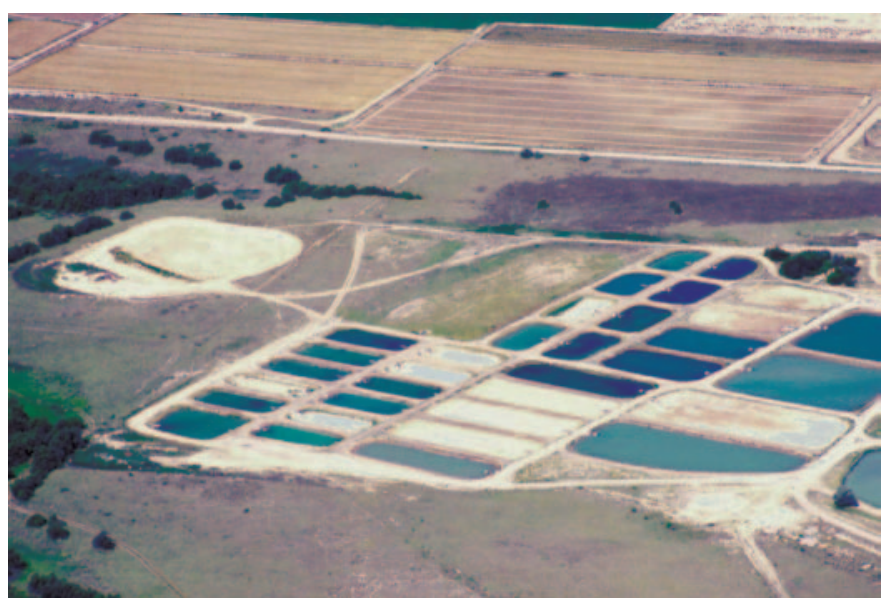

Fig. 2. Aerial photograph of Dexter National Fish Hatchery and Technology Center's rearing ponds located near Dexter, New Mexico. Photo courtesy of Manuel Ulibarri, U.S. Fish and Wildlife Service. 
Table 1. Major propagation facilities for bonytail and/or razorback sucker that are stocked in the Colorado River Basin.

\begin{tabular}{|c|c|c|c|c|c|}
\hline Facility & Agency & Bonytail & Razorback & $\begin{array}{l}\text { Recent broodstock } \\
\text { RZB or BT (\#) }\end{array}$ & Year started ${ }^{a}$ \\
\hline \multirow[t]{2}{*}{ Dexter NFH } & U.S. Fish and Wildlife Service & $\mathrm{X}$ & & BT $(2,500)$ & 1981 \\
\hline & & & $\mathrm{X}$ & RZB (300) & 1981 \\
\hline Willow Beach NFH & U.S. Fish and Wildlife Service & $\mathrm{X}$ & $\mathrm{X}$ & RZB (wild) ${ }^{b}$ & 1974 \\
\hline Achii Hanyo $^{c}$ & U.S. Fish and Wildlife Service & $\mathrm{X}$ & $\mathrm{X}$ & Grow-out & 1998 \\
\hline Ouray NFH & U.S. Fish and Wildlife Service & $\mathrm{X}$ & $\mathrm{X}$ & RZB (660) & 1986 \\
\hline Grand Valley Facility ${ }^{\mathrm{d}}$ & U.S. Fish and Wildlife Service & & $\mathrm{X}$ & RZB (300) & 1992 \\
\hline Native FWG ${ }^{e}$ & U.S. Bureau of Reclamation & $\mathrm{X}$ & $\mathrm{X}$ & Wild larvae $^{f}$ & 1990 \\
\hline Wahweap SFH & Utah Division of Natural Resources & $\mathrm{X}$ & $\mathrm{X}$ & RZB $(600)^{\mathrm{g}}$ & 1993 \\
\hline Bubbling Ponds & Arizona Game and Fish Department & & $\mathrm{X}$ & Grow-out & 1984 \\
\hline Mumma & Colorado Department of Wildlife & $\mathrm{X}$ & $\mathrm{X}$ & Grow-out & 2000 \\
\hline
\end{tabular}

${ }^{\text {a }}$ Started endangered fish propagation.

${ }^{\mathrm{b}}$ Spawners taken from Lake Mohave, spawned, and returned.

'Satellite facility of Willow Beach NFH.

${ }^{\mathrm{d}}$ Sites included Horsethief Refugia Ponds, 24-Road Hatchery, and Clymer's Pond.

'Partners include the U.S. Fish and Wildlife Service, Arizona Game and Fish Department, Arizona State University, National Park Service, U.S. Geological Survey, and Nevada Department of Wildlife.

'Wild larvae captured for propagation from Lake Mohave.

${ }^{g}$ Holds back-up broodstock for Ouray NFH.

Recovery Program uses nine grow-out ponds (11.3 ha) located southwest of Farmington, New Mexico, to raise razorback sucker to $>30 \mathrm{~cm}$ before releasing them into the San Juan River (Ryden, 1997).

Wahweap State Fish Hatchery (Wahweap SFH) began raising bonytail and razorback sucker in 1993. While the facility does not spawn fish, it does maintain a back-up broodstock of Green River razorback sucker in case something happens to

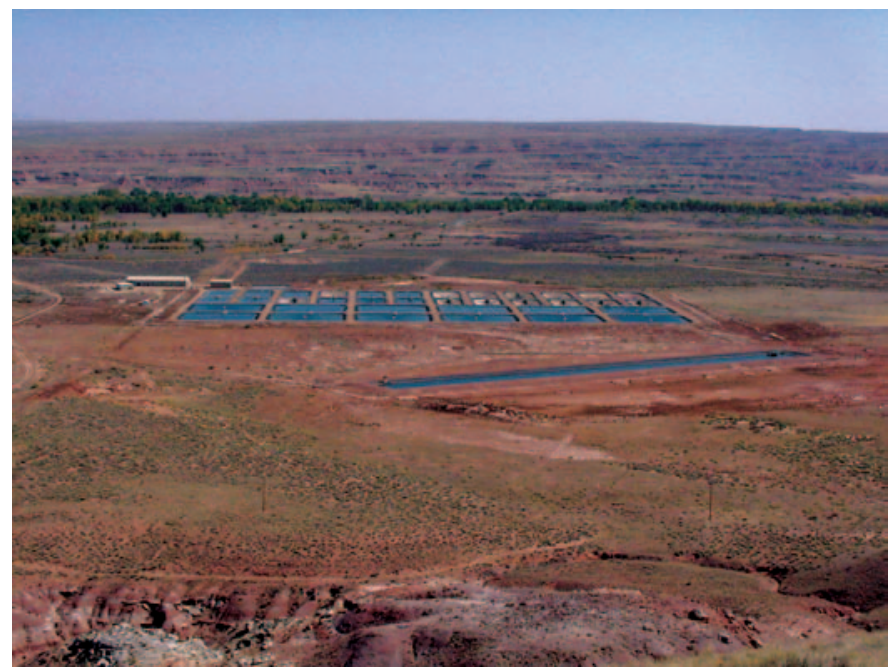

Fig. 3. Aerial photograph of Ouray National Fish Hatchery located near Vernal, Utah. Photo courtesy of Tom Czapla, U.S. Fish and Wildlife Service. the Ouray NFH broodstock. The facility is located near Blue Water, Utah, and is operated by the Utah Division of Natural Resources (UDNR) (fig. 4).

The newest rearing facility is the Mumma or the Native Aquatic Species Restoration Facility (Mumma) located west of Alamosa, Colorado, operated by the Colorado Division of Wildlife (CDOW). The hatchery opened in 2000 and has raised both bonytail and razorback sucker from fish obtained

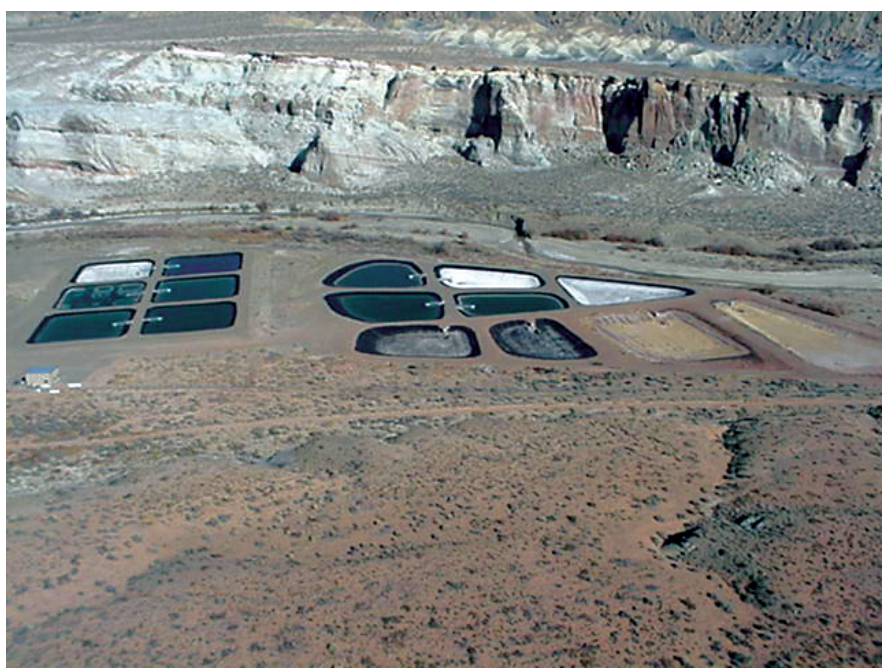

Fig. 4. Aerial view of Wahweap State Fish Hatchery located near Blue Water, Utah. Photo courtesy of Quent Bradwisch, Utah Department of National Resources. 
from other sources. Currently, the facility is raising bonytail to meet state and federal stocking requirements in the Green and Colorado Rivers.

The Native Fish Work Group (NFWG) of the lower Colorado River basin began activities on Lake Mohave in 1989 as a multiagency work group for the purpose of preventing the disappearance of razorback sucker from the reservoir (Mueller, 1995). Efforts to have wild fish spawn in isolated backwaters gradually evolved to collecting wild larvae from the reservoir and raising them to a size large enough to ensure survival. During the past decade, more than 500,000 larvae have been collected and transferred to Willow Beach NFH for initial rearing (Tom Burke, Bureau of Reclamation [BOR], oral. commun., 2004). Some fish are moved to other locations for further grow-out, while others are reared on-site (fig. 5).

Stocking programs have expanded in recent years due to the increased demand for cultured fish. As a result, several other culturing facilities were modified or built to help meet production goals (table 1). Other locations that are or recently have been used to grow-out razorback sucker include: Bubbling Ponds, Arizona; Niland, California; golf course ponds in Page, Arizona and Boulder City, Nevada; Parker, Arizona; and Lake Mohave backwaters (Mueller, 1995; Mueller and Wick, 1998).

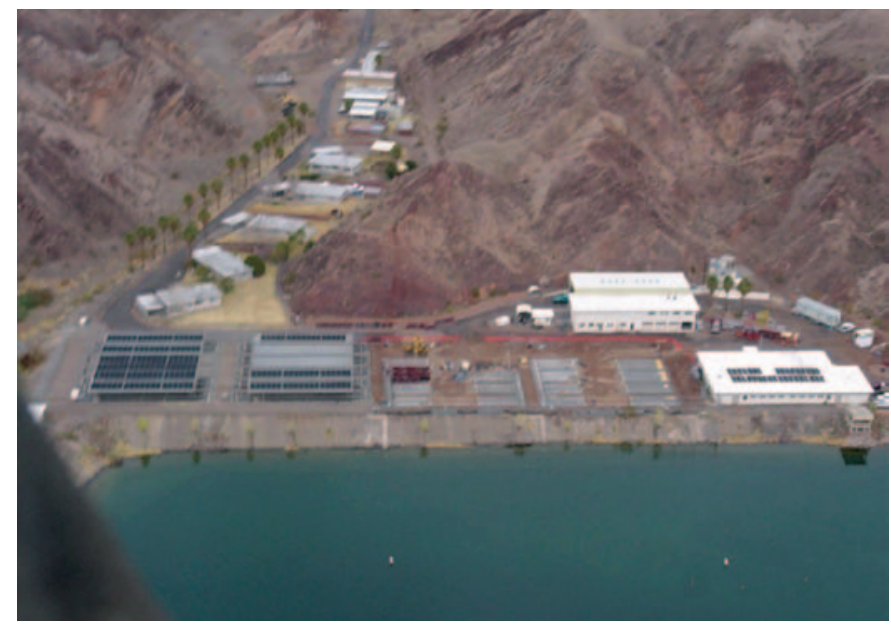

Fig. 5. Aerial view of Willow Beach National Fish hatchery located downstream of Hoover Dam at Willow Beach, Arizona. During the past decade the hatchery has installed solar panels and heat exchangers to increase water temperatures to optimize fish growth. Photo courtesy of Chester Figiel, U.S. Fish and Wildlife Service.

\section{Stocking Programs and Relative Success}

Stocking projections for the Colorado River Basin in 2005 include 55,000 large (>15 cm) bonytail, 98,000 large $(>30 \mathrm{~cm}$ ) razorback sucker and tens of thousands of razorback sucker larvae (Roger Hamman and others, U.S. Fish and Wildlife Service [USFWS], oral commun., 2005). The vast majority of these fish originate from the Ouray, Willow Beach, Grand Valley, and Dexter hatcheries (fig. 6, table 1).
The following is a brief description of a few of the major stocking efforts.

\section{Central Arizona}

Reintroduction programs resulted in limited success (Minckley and others, 1991; Mueller, 2003; Burdick, 2003; Clarkson and others 2005). The 1980's attempt to reestablish razorback suckers in historical habitats within the Gila River basin in Arizona failed. More than 12 million small suckers were stocked but less than 200 were encountered (Minckley and others, 1991). Marsh and Brooks (1989) showed that resident catfish could decimate an entire stocking within a few days. These losses prompted hatcheries to shift toward stocking larger fish that have improved survival (Mueller, 1995; Burdick and Bonar, 1997; Ryden, 1997). The Arizona Game and Fish Department (AGFD) continues to stock razorback sucker in the Verde River; bonytail have not been stocked due to political issues with water users and developers.

\section{Senator Wash, California}

Senator Wash Reservoir is a Bureau of Reclamation (BOR) operated off-site pump-back storage facility located just upstream of Imperial Dam. Razorback sucker established a small population when the reservoir was initially filled in 1966. Population estimates during the mid-1980's placed the population at approximately 50 fish, which prompted a stocking program (Ulmer and Anderson, 1985). The population was augmented between 1987 and 1990 with nearly 4,800 razorback suckers, and recent estimates place the population at nearly 1,000 fish (Laura Lesley, [AGFD], oral commun., 2004).

\section{Lake Mohave}

A stocking program in Lake Mohave was started to augment the declining native population of razorback suckers in 1992 (Mueller, 1995). Roughly 84,000 fish were stocked during 1992-2003, but survival has been low. Marsh and others (2005) have estimated that a population of approximately 1,500 young adults has been established, and survival is closely correlated to size. Survival rates dramatically increase when stocked fish are $>30 \mathrm{~cm}$ and nearly double for fish $>35 \mathrm{~cm}$ (fig. 7). Spawning continues but young continue to be lost to predators. Viable young are collected from the reservoir and raised in isolated ponds to perpetuate the genetic diversity of the community (Dowling and others, 2005).

\section{Lake Havasu}

A concerted effort to stock more than 30,000 large bonytail and razorback suckers began in 1993. The majority 


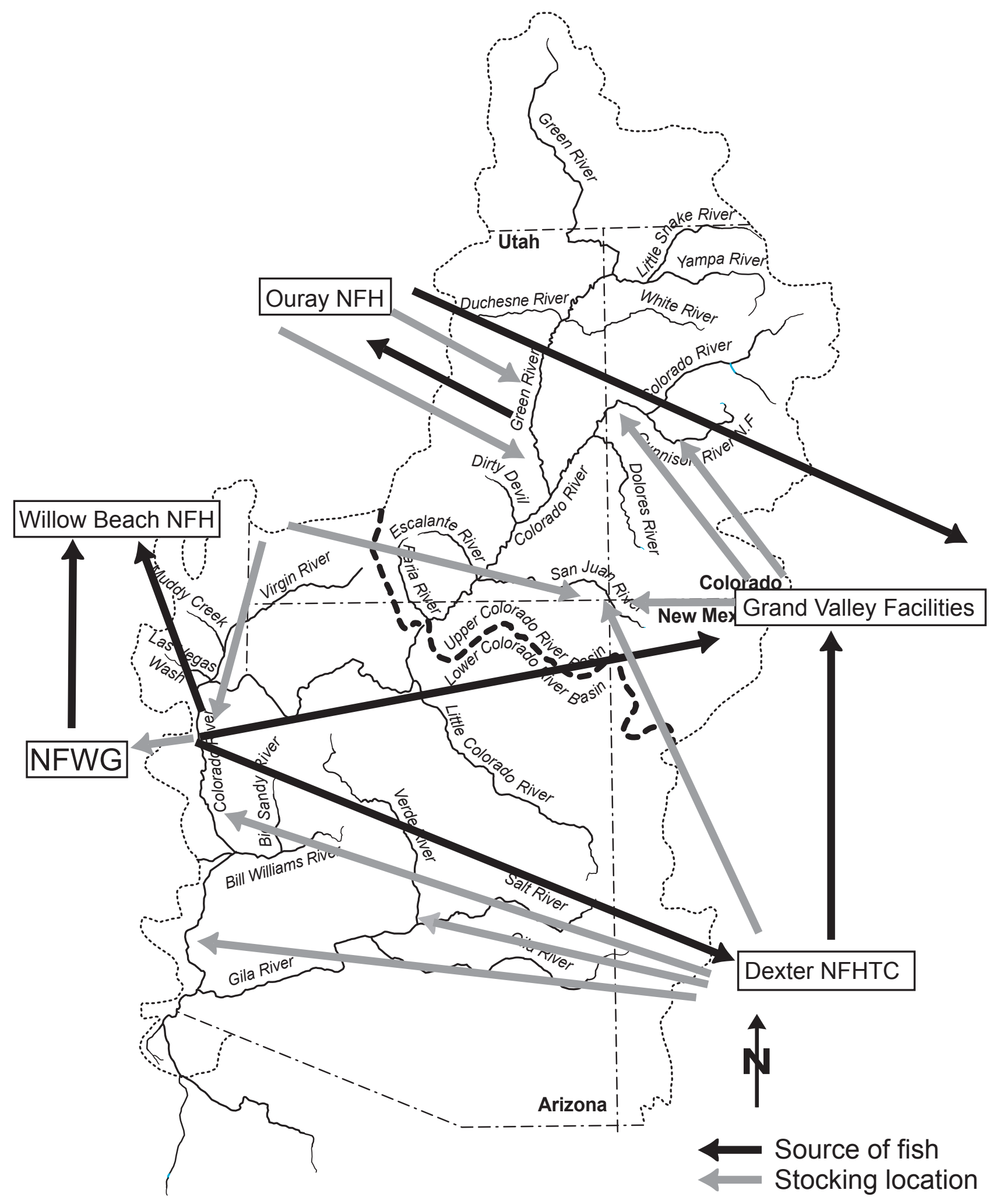

Fig. 6. Diagram showing the origin of small fish or broodstock for major facilities propagating razorback sucker in the Colorado River Basin and the final destination for those fish. 


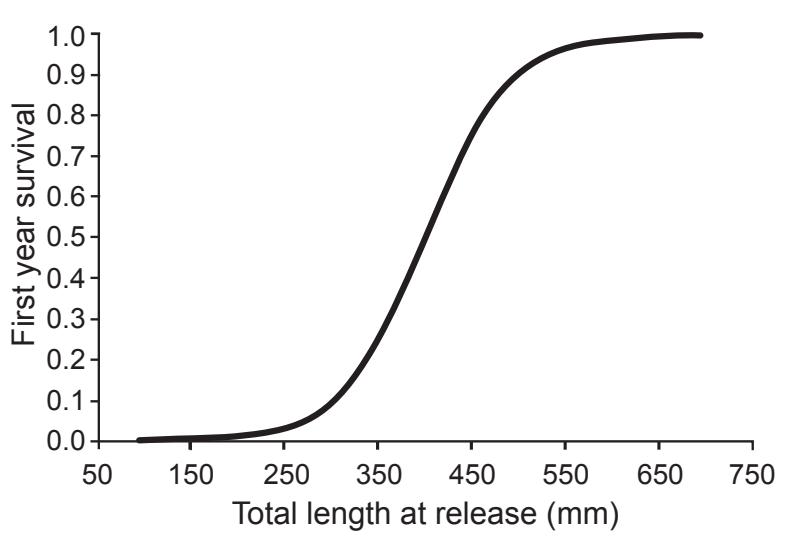

Fig. 7. Comparison of razorback sucker stocking size compared with actual first year survival based on recapture data collected from Lake Mohave. Database includes $>80,000$ stocked fish. Graph courtesy of Paul Marsh, Arizona State University, Tempe.

of these fish were stocked in Lake Havasu as part of the Lake Havasu Fisheries Improvement Program. Bonytail continue to remain extremely rate (1-2 fish per year); however, in 2005 approximately 1,500 razorback suckers were discovered reoccupying a historic spawning bar near Needles, California. Suckers are migrating to this area approximately $50 \mathrm{~km}$ upstream of the reservoir. Spawners returned to this site again in 2006, making it the largest repatriated riverine population of spawning fish in the basin.

\section{Lower Colorado River (Downstream of Parker Dam)}

The Colorado River between Parker Dam and the Mexican border has been the recipient of the second largest number of razorback suckers, an estimated 2.2 million fish (Jason Schooley, ASU, oral commun., 2005). Razorback suckers were first stocked in 1980 with more than 2 million small fish introduced between 1986 and 1990. Stocking has continued on an annual basis since 1995 using larger, but fewer, fish. Since 2001, nearly 40,000 relatively large razorback suckers have been stocked. Current surveys have only recovered recently stocked fish, suggesting overall survival during the past two decades has been exceedingly poor. Recaptures have been too few to estimate population size or survival (Schooley and Thornbrugh, 2004).

\section{Upper Colorado River}

Razorback suckers and bonytail were first stocked in the Upper Basin in 1988 (Chart and Cranney, 1993; Pitts and Cook, 1997). Large-scale reintroductions began in 1998 with bonytail and razorback sucker being stocked in the Colorado and Green Rivers. Although, there is a specific "Green River" broodstock, razorback sucker stocked into the Green River include production from Grand Valley and Lower Basin hatchery facilities (Tim Modde, USFWS, oral commun.,
2005). Today, stocking has expanded to include the Gunnison and Yampa rivers. Attempts to reestablish these fish have seen limited success; survival of large hatchery-reared fish remains poor (Bestgen and others, 2002). Recaptures have been inadequate to estimate population size. As experienced in the Lower Basin, survival appears closely correlated to stocking size (Burdick and others, 1995; Ryden, 1997).

\section{San Juan River}

Razorback sucker have been stocked in the San Juan River since 1997, and larvae have been collected in recent years (Mueller and others, 2001; Brandenburg and others, 2003; Ryden, 2003a and 2003b). During the past year, about a half dozen one-year-old fish were collected (Dale Ryden, USFWS, oral commun., 2005).

\section{Prognosis}

Larger adult razorback suckers produced in hatcheries are surviving and beginning to spawn, but no self-sustaining population has been produced. The predation problem remains unresolved. Recovery actions are treating the symptom (low numbers of fish) but have not effectively dealt with the problem (predation). Predation continues to restrict natural recruitment throughout the basin (Minckley and others, 1991; Tyus and Saunders III, 2000; Mueller, 2003). Resource management agencies continue to wrestle with the conflict between native fish management and recreational fisheries, hoping somehow the two programs can be compatible. Unfortunately, there does not seem to be any evidence they can, and the results have manifested into a totally displaced fish fauna.

\section{Study Objectives}

The purpose of this report evolved with its writing. Initially, the goal was to summarize the work conducted at Cibola High Levee Pond (CHLP). This included reviewing the status of these two fish, identifying causes for their endangerment, and describing why natural recruitment was occurring at CHLP. However, it became increasingly evident that CHLP mimicked historical ecological features that disappeared when large water development projects harnessed the river. The ability of these riverine species to produce young in small, isolated habitats may provide the key to their recovery. This belief is based on 25 years of personal observations combined with the fact that recovery programs have been unable to reestablish self-sustaining populations in the mainstem river.

The report was expanded to elaborate on the function of isolated communities and how manmade sanctuary habitats actually mimic historical conditions that existed prior to large water development projects. Off-channel sanctuaries provide 
a realistic approach to advance research and recovery of these two species.

This report is presented in three chapters. The first, "The Fish" summarizes the life histories and ecological relationship of the bonytail (Gila elegans) and razorback sucker (Xyrauchen texanus). The second, "Complete Life Cycle of Two Endangered Fishes at Cibola High Levee Pond" provides a description of the physical and biological attributes of the pond, a brief account of its history and management recommendations. The third, "Oxbow Communities: The Missing Key to Recovery?" describes the need and potential role that sanctuary communities serve in the ecology, conservation, and recovery of these and possibly other native fishes.

\section{Ecology of Bonytail and Razorback Sucker}

The following summaries on the life history and ecology of bonytail and razorback sucker are based on research conducted from the mid-1960's to the present. Much of the information summarized here is presented in more detail elsewhere. I strongly encourage readers to review these sources of information. An interactive bibliography containing more than 3,000 references for the big river fishes was developed for this project by Arizona State University (Pacey and Marsh, 2001, 2005) and can be accessed at http://www.fort.usgs.gov/products/publications/co_fishbib/co_fishbib.asp.

\section{Capture Techniques}

\section{Bonytail}

Larvae

Bonytail larvae are phototactic (Snyder and Meismer, 1997; Mueller and others, 2002) but have two disadvantages: they are small $(6-8 \mathrm{~mm})$, and hatch later in the season when predators are more active (Snyder and others, 2004). This led to a problem of detecting them in light trap samples (table 2). Sixty-four overnight (818 total hours) light trap sets yielded no bonytail larvae among numerous invertebrates. In lieu of leaving traps set overnight, I set four for only 2 hours and captured five bonytail larvae in three of the four traps. It is possible that overnight sets experience in-trap predation by odonate nymphs. I was unable to test that theory.

\section{Larger Bonytail}

Techniques used to capture bonytail have remained unchanged for centuries. Local tribes used dip nets, seines, fish traps, and fashioned hooks (Wallace, 1955; Stewart, 1957). Archaeologists have reported the rock remains of hundreds of fish traps found along the ancient shoreline of Lake Cahuilla, the enhanced version of the Salton Sea (fig. 8).
Table 2. Catch rate of bonytail larvae and invertebrate taxa captured in light traps set in Cibola High Levee Pond in 2002. Sixty trap sets were left overnight; four were removed after 2 hours.

\begin{tabular}{lc}
\hline \multicolumn{1}{c}{ Organism } & Average per set ${ }^{\mathrm{a}}$ \\
\hline Bonytail (traps set overnight) & 0.00 \\
Bonytail (traps set for 2 hours) & 1.25 \\
Dragonfly nymphs (Anisoptera) & 1.25 \\
Mayfly nymphs (Ephemeroptera) & 5.99 \\
Damselfly nymphs (Zygoptera) & 10.99 \\
Scuds (Amphipoda) & 88.98 \\
Water boatman (Hemiptera) & 302.94 \\
\hline${ }^{a} n=64$.
\end{tabular}

The structures date back to 700 A.D. and many were found to contain bonytail and razorback sucker bones (Schaefer, 1986).

Historically, bonytail was one of the most easily caught fish in the river basin and have been taken by hook-and-line on baits that include worms, cheese, dough balls, and lettuce (Blake, 1864; Sleznick, NPS-retired, oral commun., 2001). Hatchery-produced bonytail have recently been taken by anglers in both Lake Mohave and Lake Havasu (Mueller and Marsh, 2002; Kirk Koch, BLM, oral commun., 2004). Hatchery personnel report they are easily taken on artificial flies.

Biological surveys, on the other hand, have relied heavily on the use of trammel nets and electrofishing. Recently, the use of electroshocking has become controversial due to reported hemorrhaging and spinal damage (Snyder, 2003). Ruppert and Muth (1997) reported a high incidence of internal hemorrhaging in young bonytail and razorback sucker. How-

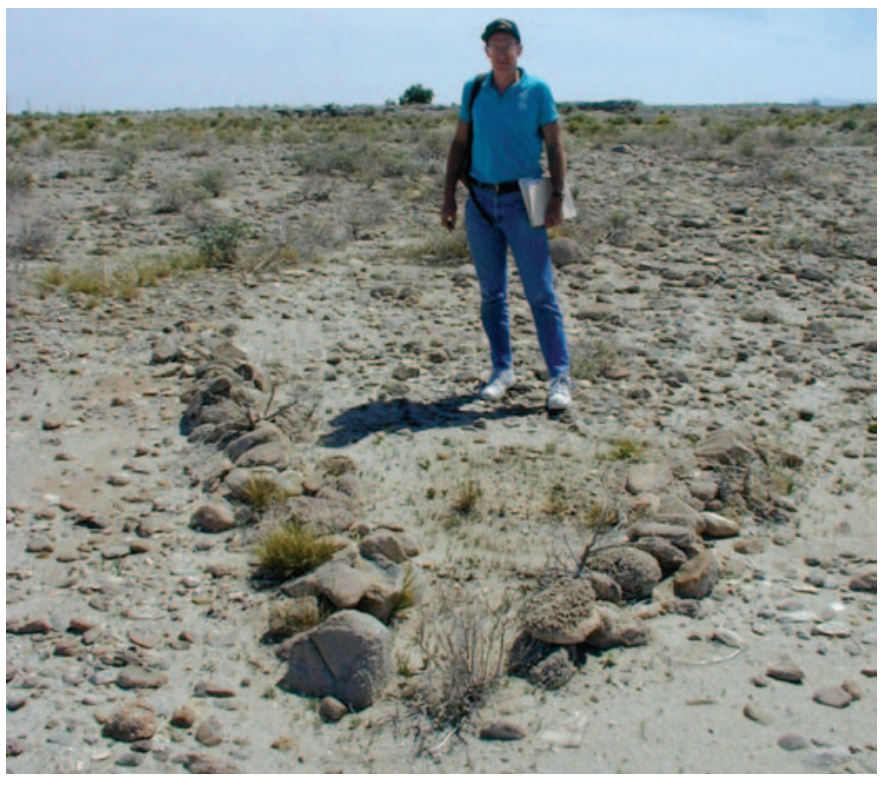

Fig. 8. Photograph of an ancient rock fish trap located near the Salton Sea, California. Photo courtesy of Eric White, Bureau of Reclamation. 
ever, this collection technique is still being used in lieu of a more effective method.

Trammel netting has been the preferred method to capture bonytail in reservoirs for nearly three decades (Minckley and Thorson, 2002, 2003, 2004) (fig. 9). Annual surveys are typically conducted in the spring when fish are suspected to spawn. Trammel nets are typically set at dusk and checked every 2 hours to remove entangled fish. Unfortunately, sampling coincides with the spawning of several other species, including common carp. In the Lake Mohave surveys, several hundred common carp are captured for each bonytail taken (Minckley and Thorson, 2002, 2003, 2004) (fig. 9).

Trammel nets are also effective in streams when fished in backwater or along eddy lines where there is a stark contrast in currents. Here bonytail are often captured near the surface, close to shore, especially near areas where fish have access to large submerged rock talus (Paul Badame, UDNR, oral commun., 2005).

We have tried other methods of capture, such as large cyclical fish traps, square traps, hoop nets with wings and leads, and electrofishing (table 3 ). Hoop nets set in the current have proven very effective for other Gila spp. (Douglas and Marsh, 1996), but based on our low catch rates ( $<1$ fish/set), it appears bonytail easily avoid and/or escape traps set in standing water.

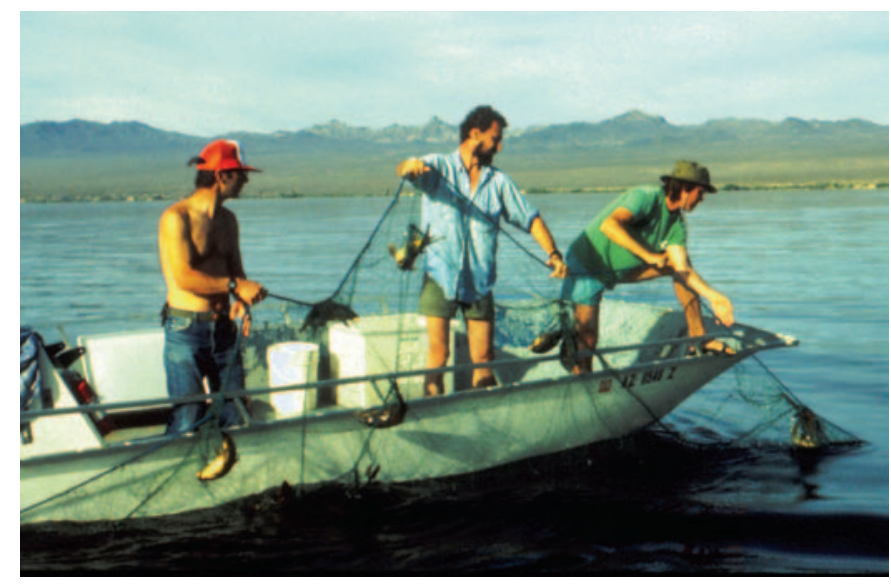

Fig. 9. Trammel nets are the standard method of capturing bonytail in Lake Mohave. Arizona State University has been conducting annual "bonytail roundups" for more than three decades. Shown here are Paul Marsh (left) and his crew inspecting a carp-laden net for bonytail.

\section{Razorback Sucker}

\section{Larvae}

Larvae are phototactic and readily captured with lights and small dip nets. W.L. Minckley developed the technique of sitting on a bucket placed upside down in the shallows and attracting larvae with a spotlight. The technique has been improved using underwater halogen lights suspended over the side of a boat which is beached near a spawning area (figs.10
Table 3. Capture rates of minnow traps, hoop nets, box traps, fyke nets, trammel nets, and electrofishing used to capture bonytail at Cibola High Levee Pond from 2001 through 2004.

\begin{tabular}{lccccc}
\hline Technique & Effort (h) & Bonytail & Bonytail (h) & Crayfish $^{\mathbf{a}}$ & Tadpoles $^{\mathbf{a}}$ \\
\hline $\begin{array}{l}\text { Minnow } \\
\text { trap }\end{array}$ & 286 & 115 & 0.4 & 251 & 421 \\
Hoop net & 366 & 111 & 0.3 & 0 & 0 \\
Box trap & 384 & 11 & $<0.1$ & 19 & 15 \\
Fyke net & 642 & 49 & $<0.1$ & 13 & 75 \\
Trammel & 214 & 1,174 & 5.5 & 0 & 0 \\
net & & & & & \\
Electro- & 4.6 & 460 & 100.0 & 0 & 0 \\
fishing & & & & & \\
\hline
\end{tabular}

ancludes only partial counts. Initially these organisms were not counted.

and 11). Often prevailing winds concentrate larvae along shore, making them easier to collect. Under ideal conditions, volunteers have dip netted $>10,000$ larvae in one evening. More than 500,000 sucker larvae have been individually dip netted by Native Fish Work Group (NFWG) volunteers from Lake Mohave during the past decade (Tom Burke, Bureau of Reclamation, oral commun., 2004). Collected larvae are transported to Willow Beach NFH where they are raised to 35 $\mathrm{cm}$ before being reintroduced into the reservoir.

Larvae can also be captured using light traps (Muth and Haynes, 1984; Mueller and others, 1993; Snyder and Meismer, 1997) (fig. 11). Studies conducted in both riverine and reservoir settings have successfully captured larvae using light traps set near or downstream of spawning areas. Mueller and others (1993) examined capture rates using bait and three different light intensities. Traps baited with dog food yielded only $<0.06$ larvae/hour. Traps illuminated with cyalume sticks produced $<0.2$ larvae/hour compared to nearly 29.8 larvae/ hour for traps equipped with 12-watt (12 vdc) lights. However, in-trap larval predation by odonates and small fishes proved to be a problem, which became more evident as waters warmed and organisms became more active. Larger fish, especially centrachids, often position themselves at the trap's entrance and intercept unsuspecting larvae as they approach (Horn and others, 1994; Mueller and others, 2001).

\section{Larger Razorback Suckers}

One of the most bizarre tales of collecting these fish came from a local resident. George Utley reported taking 147 razorback suckers in an hour using a hand axe and .22-caliber rifle in Imperial Valley (Odens, 1989). Razorback sucker have rarely been captured by recreational anglers due to their planktonic diet but they are quite vulnerable to electrofishing, seines, and passive netting such as gill nets, trammel nets, hoop nets and fyke nets. They are most vulnerable when they congregate in the shallows to spawn.

Electrofishing is the preferred method to sample streams (Muth, 1995) and has proved to be the most effective at 


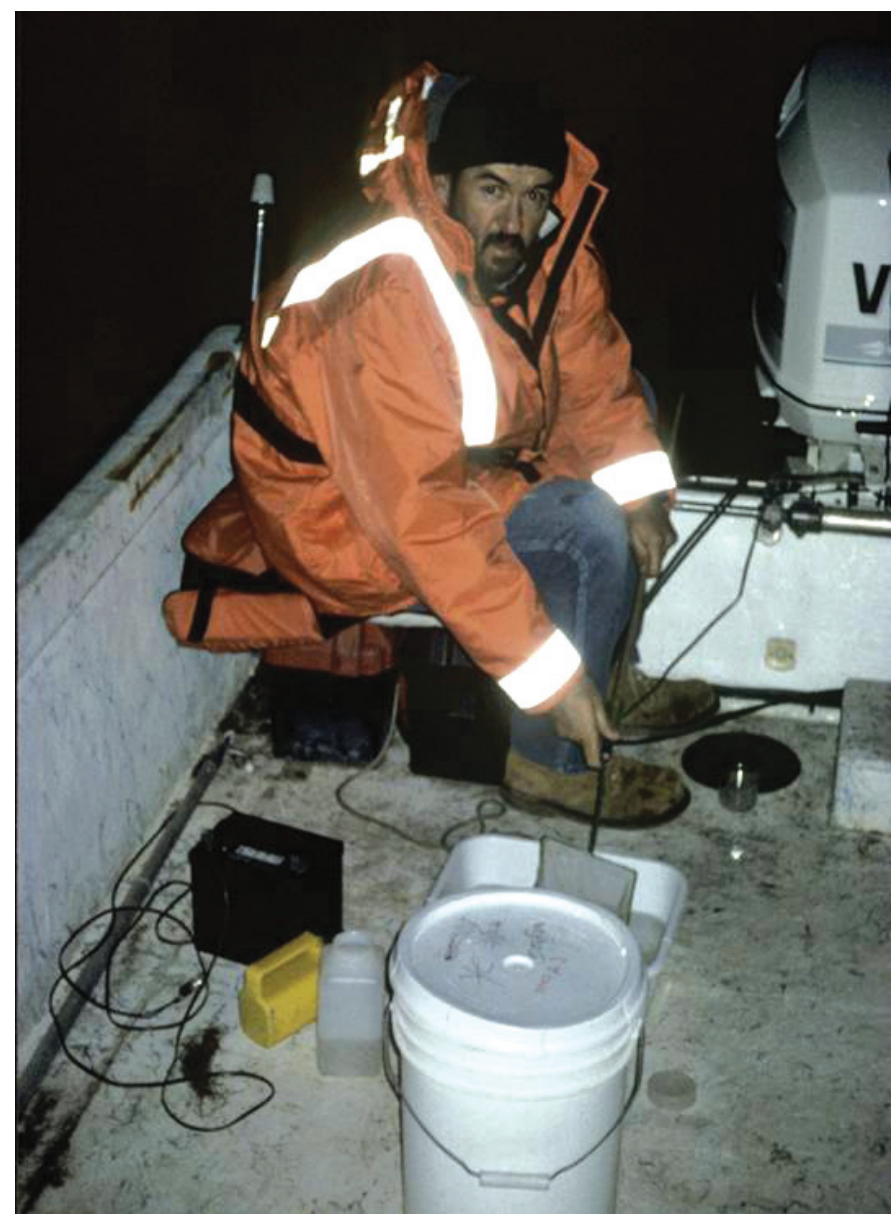

Fig. 10. Tom Burke, Bureau of Reclamation, refined hand-collection techniques for razorback sucker larvae. Collection equipment includes a small meshed aquarium dip net, a halogen light and 12-vdc battery, wash tub, 5-gallon bucket, and a thermos of hot coffee. Larvae are individually netted by hand.

CHLP. It was 100 times more productive (fish/hour) than passive netting techniques (table 4). However, as previously mentioned, recent studies suggest electrofishing can cause detrimental harm to all life stages (Muth and Ruppert, 1996, 1997; Snyder, 2003). If improperly used, strong electric currents can cause severe spinal injuries and even death to larger fish (fig. 12).

Juveniles are seldom captured in the wild, and the only experience in their capture is at rearing facilities. Young suckers are inclined to enter hoop nets and large minnow traps, especially when disturbed and when other forms of cover are scarce (Ty Wolters, BOR, oral commun., 2004).

Trammels are widely used but caution needs to be taken using gear that can accidentally "gill" fish. For example, small $(10-12 \mathrm{~cm})$ suckers are extremely susceptible to gilling in 1.2$\mathrm{cm}$ trammel nets. Trammel nets were the second most effective method and the most productive of the passive techniques used. Multifilament nets averaged 0.9 razorback suckers per hour year round. They are especially effective during the spawning season, when fish are congregated and active.

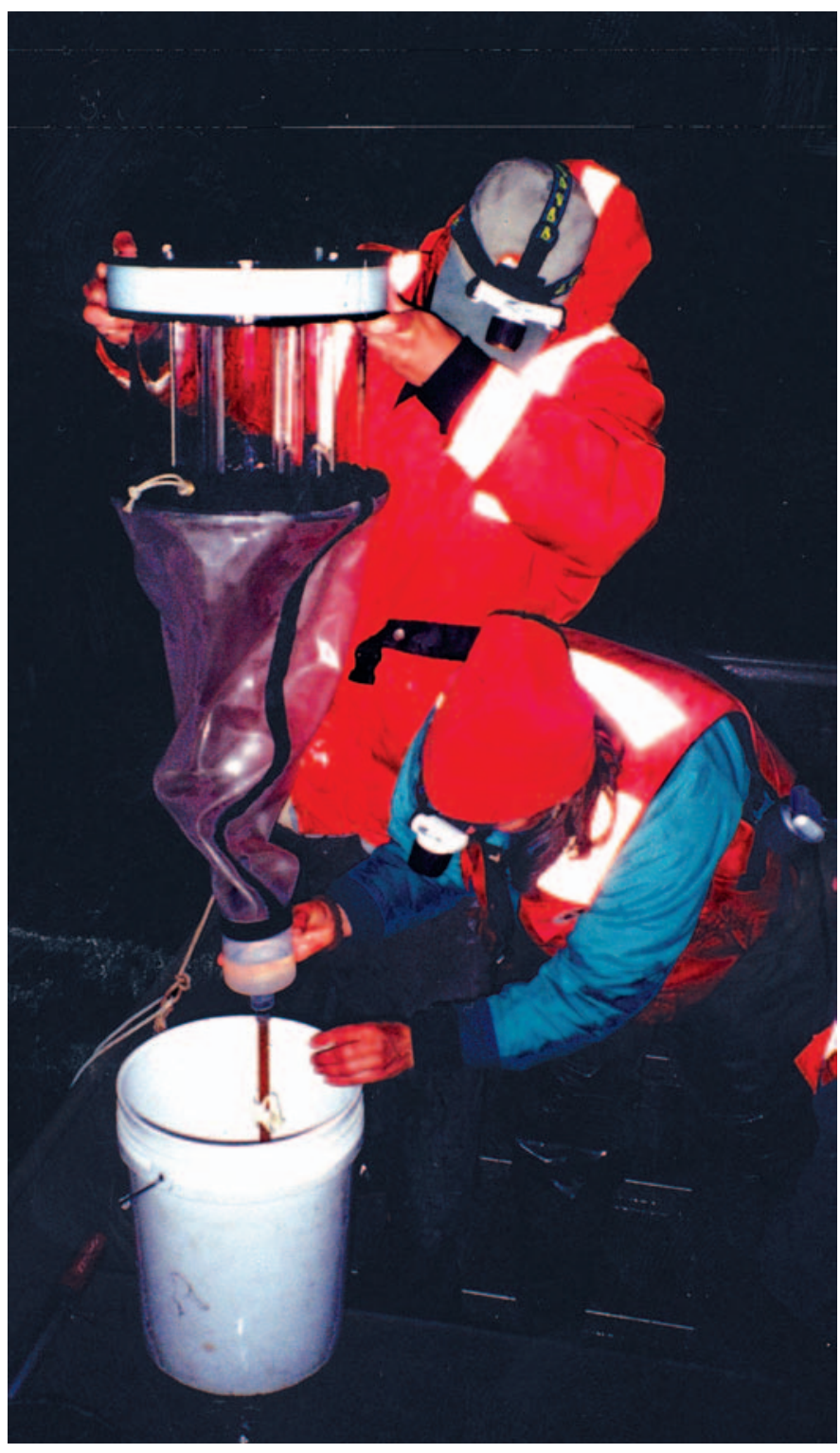

Fig. 11. U.S. Geological Survey biologists drain the contents of a floating light trap for future examinations. Light traps are effective in determining the presence of larvae.

Researchers expended more than 1,600 hours of effort trying other, less stressful capture techniques but were unsuccessful in finding an effective substitute for either electrofishing or trammel netting. Researchers attempted baiting hoop nets and traps with dry dog food and canned cat food. While this increased catch, it also increased the incidence of crayfish and crayfish-related mortality for small entrapped fishes.

In most instances, trammel nets are set overnight and checked in the morning. Adults seldom struggle, and netting abrasions and mortality are rare. During the Cibola study, 800 adult razorback suckers were captured without a single netting-related mortality. However, netting should be avoided during the summer. Subjecting fish to thermal or oxygen stress can result in chronic stress and lead to death. 
Table 4. Capture rates of minnow traps, hoop nets, box traps, fyke nets, trammel nets, and electrofishing used to capture razorback sucker at Cibola High Levee Pond from 2001 through 2004.

\begin{tabular}{lccccc}
\hline \multicolumn{1}{c}{ Technique } & Effort (h) & $\begin{array}{c}\text { Razorback } \\
\text { sucker }\end{array}$ & RZB/h & Crayfish $^{\mathbf{a}}$ & $\begin{array}{c}\text { Tad- } \\
\text { poles }^{\mathbf{a}}\end{array}$ \\
\hline Minnow trap & 286 & 0 & 0.0 & 251 & 421 \\
Hoop net & 366 & 77 & 0.2 & 0 & 0 \\
Box trap & 384 & 0 & 0.0 & 19 & 15 \\
Fyke net & 642 & 27 & $<0.1$ & 13 & 75 \\
Trammel net & 214 & 188 & 0.9 & 0 & 0 \\
Electro- & 4.6 & 282 & 58.5 & 0 & 0 \\
fishing & & & & & \\
\hline
\end{tabular}

${ }^{\mathrm{a}}$ Includes only partial counts. Initially these organisms were not counted.

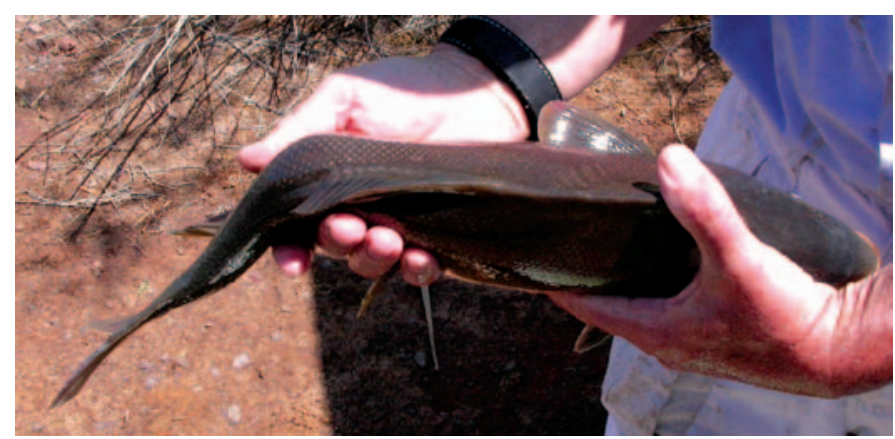

Fig. 12. Razorback sucker captured from CHLP exhibiting a spinal deformity. The exact cause of this fish's disfigurement is unknown, but similar spinal damage can be caused by electrofishing.

\section{Mortality Issues}

Bonytail are successfully cultured and used in long-term experiments (Marsh and Mueller, 1999; Badame and Hudson, 2003); however, they have a reputation for stress-related mortality (Meyers, 1992; Chart and Cranney, 1993; Tyus and others, 1999). Bonytail are susceptible to stress-related outbreaks of the disease ich (Ichthyophthirius multifilis) even under controlled hatchery conditions (Chester Figiel, USFWS, oral commun., 2004). The loss of several large adults during attempts to capture wild broodstock from Lake Mohave in the late 1980's prompted the development of stringent handling protocols designed to minimize netting and handling stress (USFWS, 1998b). Protocols recommended that nets be checked every 2 hours and when an entangled bonytail was encountered, that they be gently lifted, net and all, into a holding tank where the net is cut away to free the fish. Direct handling of fish was simply avoided whenever possible. Holding water contains a solution of $0.5 \% \mathrm{NaCl}(4.9 \mathrm{~g} / \mathrm{L}), 25 \mathrm{mg} / \mathrm{L}$ MS-222, $0.26 \mathrm{~mL} / \mathrm{L}$ stress coat, and $0.8 \mathrm{mg} / \mathrm{L}$ Chloramine-T. Hauling densities were recommended not to exceed $30 \mathrm{~g} / \mathrm{L}$ of fish to water.

We observed unusual symptoms on bonytail that were held for extended periods of time. Bonytail captured at CHLP were held in a floating live car to prevent their recapture during the routine 3-day sampling effort. While initial mortality was low $(<1 \%)$, surviving fish exhibited dark strangulation marks which in time expanded beyond their dorsal fin toward their tail (fig. 13). The fish appeared stiff, lethargic, and had difficulty swimming, exhibiting symptoms I suspect to be tissue damage that may have resulted from net strangulation.

In later experiments conducted at Willow Beach NFH, the same dark banding and other symptoms were observed on fish that were simply handled. The size of the blotching increased with time (fig. 14). All 21 bonytail used in this experiment (including controls) came down with ich and perished within 2 weeks after being handled.

These symptoms and deaths suggest bonytail may be susceptible to capture myopathy. It is also known as "white muscle disease," which is a non-infectious disease characterized by muscle damage bought about by extreme exertion, struggle, or stress. It is a common problem in capturing wild birds and mammals, especially wild ungulates (Williams and Thorne, 1996) but to our knowledge has not been reported in freshwater fish. It has been reported in capture and transport of sharks (Greenwell, 2003). Death can occur immediately or be delayed for weeks. Prevention of stress is the only way to eliminate this disease.

We are aware of two studies that actually examined the impact of post-handling stress on cultured bonytail. Craig Paukert and others (2005) handled cultured bonytail from one to seven times and monitored growth and weight gain over an 11-month period. These results were striking, with each handling event decreasing fish growth by $9.5 \%$ and weight by $24.8 \%$. Tyus and others (1999) examined the impact of acquiring genetic tissue samples from bonytail, and delayed mortality of these fish reached $77 \%$, including their controls. They suggested mortality resulted from ich infections. Likewise, Chart and Cranney (1993) reported 75\% mortality in bonytail used in telemetry studies.

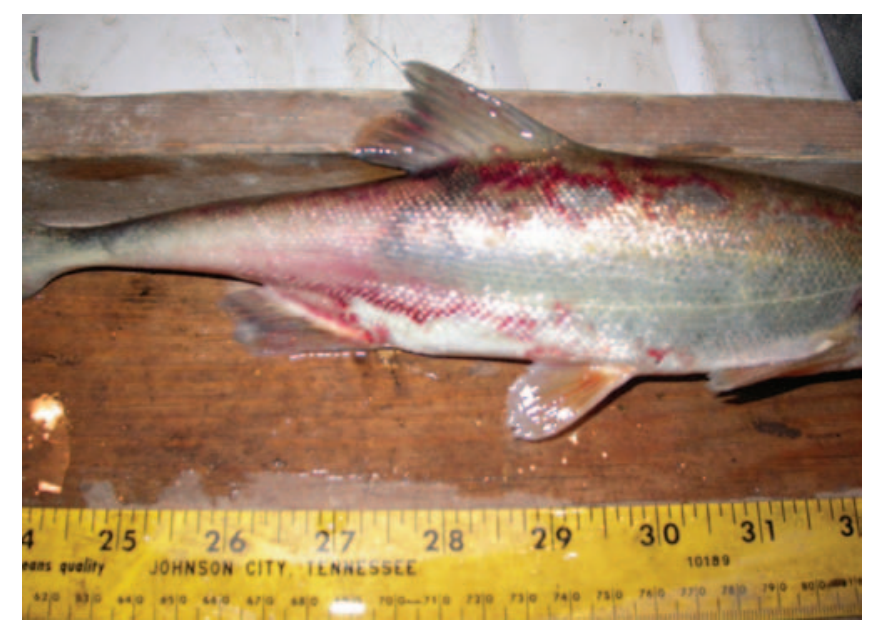

Fig. 13. Captured bonytail that were held for a few days often exhibited discoloration, swelling, stiffness, and subdermal hemorrhaging of the tail musculature. These symptoms appear stress-related and usually result in death. 


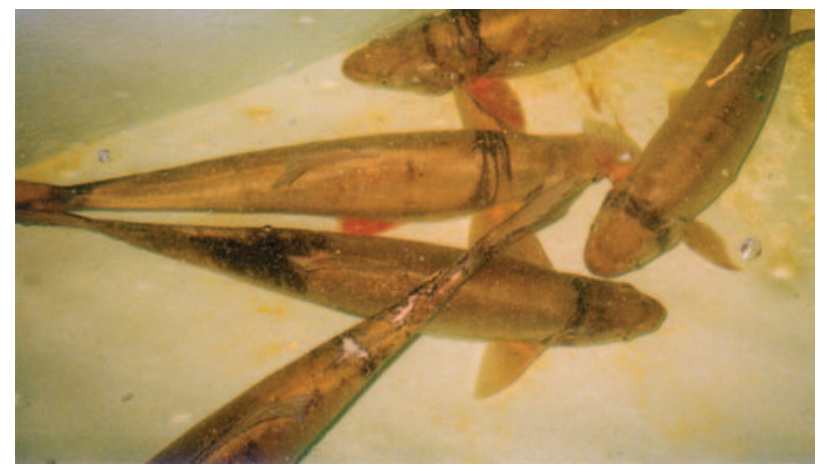

Fig. 14. Hatchery bonytail used in an experiment exhibited body discoloration or banding associated with handling (fish were not netted). All fish died 2 weeks after being handled following standard protocols (Mueller, 2004).

It is reasonable to assume that any type of disruptive stress that retards growth or triggers serious outbreaks of ich may also have profound impacts on the reproductive capability of these fish. Sampling protocols require wild bonytail and humpback chub (G. cypha) be immediately released due to their protected status. Unfortunately, this practice negates learning of the long-term impacts associated with handling stress. These problems are noteworthy and deserve closer scrutiny and study, especially in terms of monitoring programs. If Gila is susceptible to this disease, it may help explain recent declines (i.e., reduced numbers of adults, poor recruitment) in the highly monitored population of G. cypha in the Little Colorado River and the virtual absence of bonytail recaptures in the wild.

\section{Bonytail Life History}

Bonytail are endemic to the Colorado River Basin. Attempts to provide systematic accounts of fish species in the genus Gila have been difficult due to the similarity of the three species (Douglas and others, 1998). Gila elegans was described by Baird and Girard (1853) but was later suggested to be a subspecies of Gila robusta (elegans) (Miller, 1946). Smith and others (1979) reviewed the systematics of the large river forms and defined three specific taxa: Gila robusta, Gila elegans, and Gila cypha. Early field collections often lumped or entirely misidentified Gila species, making it difficult (if not impossible) to determine distribution and abundance from early reports. By 1980, bonytail were extremely rare, and the few capture records that do exist are from locations that could seldom be considered pristine habitat. The last relic population of bonytail was found in Lake Mohave, Arizona-Nevada.

Bonytail and historic habitat conditions disappeared before scientists had time to study their ecological linkages. Data before human alteration of the river provide some insight into this unique fish's habitat requirements and behavior. The most revealing evidence of their early life ecology comes from their unparalleled success at CHLP and at hatcheries where "volunteer spawn" can actually be a problem. Unlike the razorback sucker, bonytail are one of the most prolific of the native endemic fishes that are now endangered in the Colorado River.

\section{Physical Description}

The bonytail is a beautiful fish, living up to its species name that means "elegant." Newly born larvae are $<8 \mathrm{~mm}$ in length, and as they grow they resemble a "shiner" (fig. 15). Its body is highly streamlined: slightly depressed laterally: and covered with small, embedded scales. They have a very slender, round, and long caudal peduncle; hence its common name "bonytail." It has a moderately-sized subterminal mouth, and its fins are large and falcate, forming graceful lines. Juveniles are silver in color with cream-colored bellies (fig.16). Adults develop a relatively flat, concave head that precedes a smooth dorsal hump and back (fig.17).

The species is medium in size, most commonly reported in the range of 30-40 cm (McDonald and Dotson, 1960; Vanicek, 1967), but fish can reach lengths of nearly $80 \mathrm{~cm}$ (Minckley, 1979). A 80-cm bonytail was reportedly captured by an angler downstream of Davis Dam in 1975 (Minckley, 1979). However, today, fish $>40 \mathrm{~cm}$ are rare; the largest documented from CHLP was a 52-cm female. Their maximum weight ranged from 1-1.5 kg (Blake, 1864; La Rivers, 1962; Mueller and Marsh, 2002).

Young fish are typically silver-gray with white bellies. As they age, their backs gradually turn a dark olive color that contains small iridescent brass highlights that "glitter." Coloration can vary considerably among adults, and it is suspected their pigmentation can change due to light, stress or habitat conditions. A large female was captured at CHLP that had a beautiful golden yellow cast over its entire body (fig. 18). Manuel Ulibarri (USFWS, oral commun., 2004) reported a similar colored bonytail at Dexter NFHTC. That fish was not

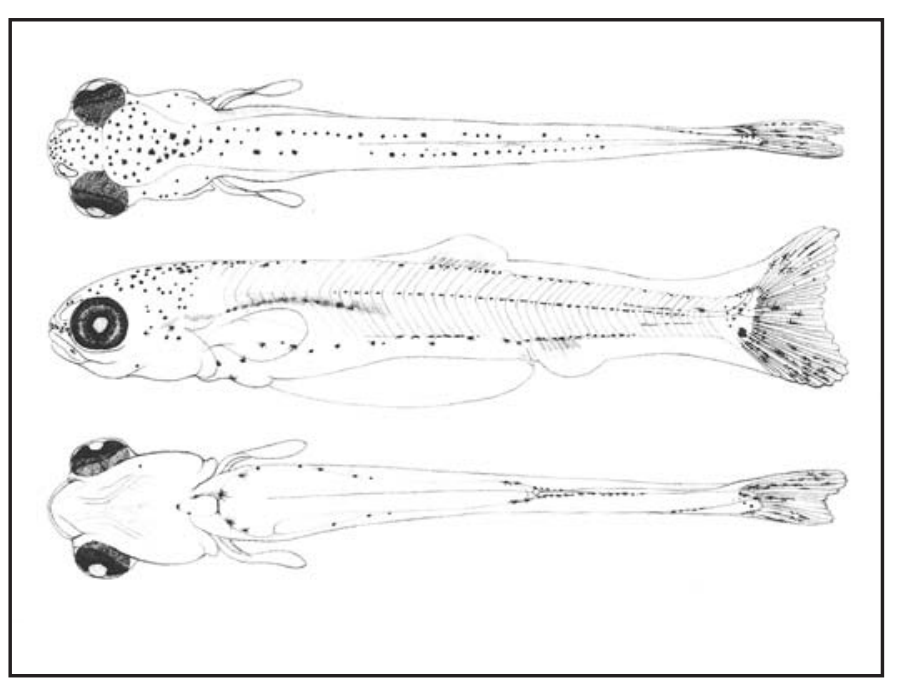

Fig. 15. A drawing illustrating the morphology of bonytail larvae. Courtesy of Robert Muth, U.S. Fish and Wildlife Service. 


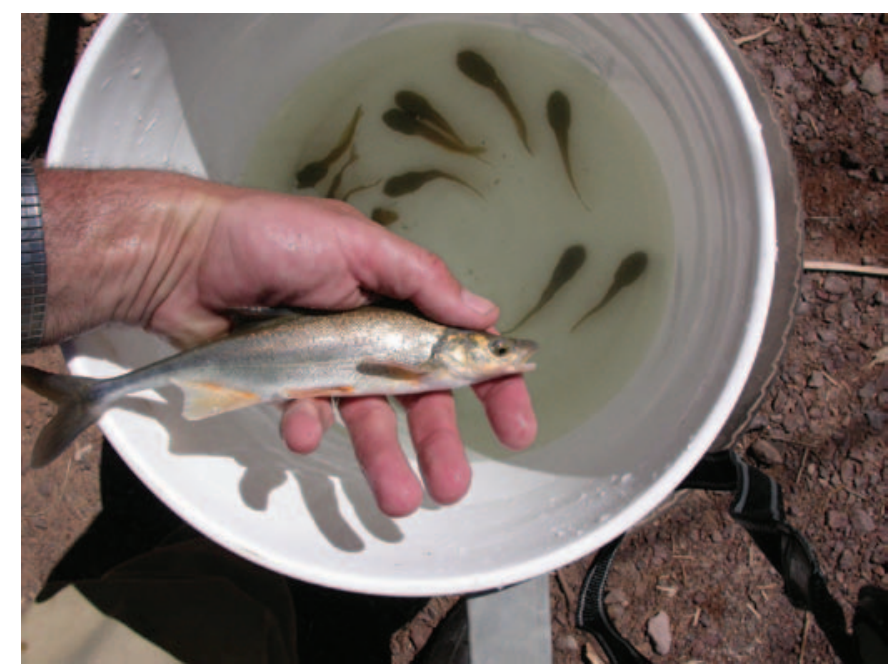

Fig. 16. A photograph showing an intermediate-sized bonytail.

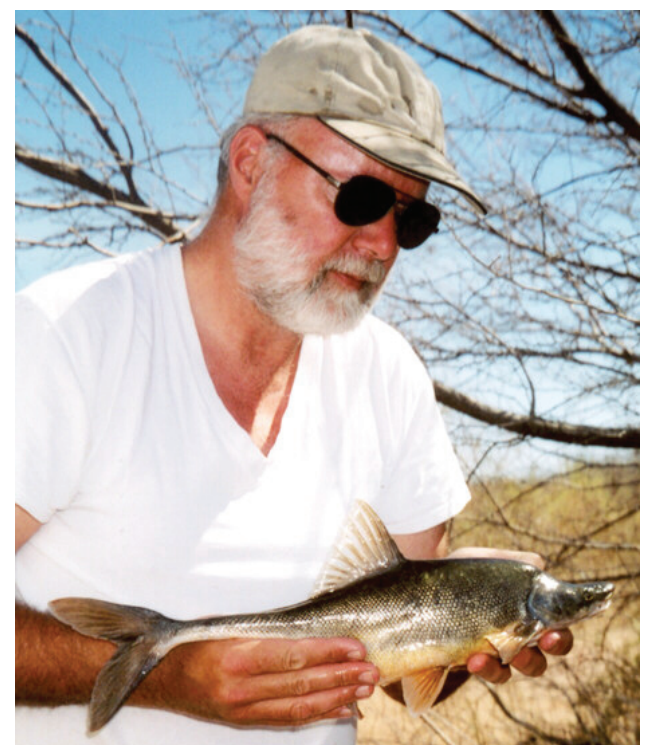

Fig. 17. Gordon Mueller (U.S. Geological Survey) holding a large $(50 \mathrm{~cm})$, mature bonytail taken from Cibola High Levee Pond, Arizona-California. Photo courtesy of Jeanette Carpenter, USGS.

noticed until it had fully matured, suggesting the pigmentation occurred with maturity.

\section{Distribution and Abundance}

The historical range of the bonytail extended from the Colorado River Delta, upstream into the major tributaries in Arizona, Utah, New Mexico, and Colorado (fig. 19) (Mueller and Marsh, 1995). By all accounts, bonytail were abundant in larger streams and their floodplain wetlands (Mueller and Marsh, 2002). W.L. Minckley suggested their sanctuary was the Colorado River delta and its associated wetlands (Mueller and Marsh, 2002).

Their range and abundance declined rapidly with the introduction on nonnative fishes and water development.

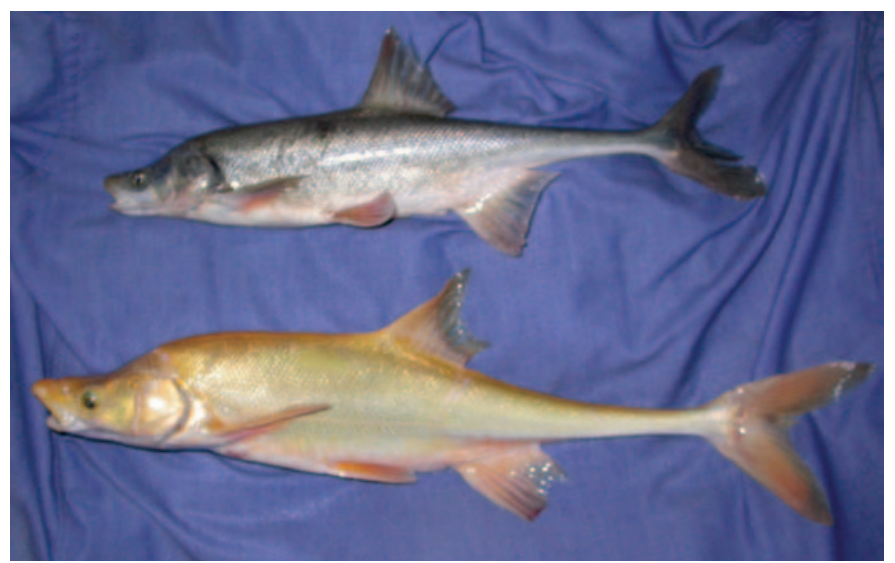

Fig. 18. Two large $(>40 \mathrm{~cm})$ bonytails. The top fish is the typical coloration of a mature adult. The lower fish is a pigmentation anomaly which was observed only once at CHLP but was also reported at Dexter NFHTC, New Mexico.

The construction of Laguna Dam in 1909 effectively isolated fish from returning upstream from the delta, and irrigation stranded thousands of bonytail and other native fishes (Miller, 1961; Mueller and Marsh, 2002). Large mainstream natives were generally gone by the mid-1930's (Dill, 1944). Anglers continued to capture a few fish until the late 1970's (Minckley, 1979; Mueller and Marsh, 2002). The exception was a wild population that developed as Lake Mohave filled and persisted until the 1990's; a few old adults may still persist.

Bonytail were still common during the pre-construction surveys for Glen Canyon and Flaming Gorge dams (McDonald and Dotson, 1960; Vanicek, 1967), however, a decade later they were declining (Vanicek, 1970; Holden and Stalnaker, 1970). Anglers captured bonytail from Lake Powell during the late 1970's and early 1980's (Valdez and others, BIO-WEST, Inc., written commun., 1994). The last wild bonytail captured in the Upper Basin were from Desolation and Cataract Canyons in 1984 and 1985 (Kaeding and others, 1986; Valdez, 1990; Valdez and others, BIO-WEST, Inc., written commun., 1994).

\section{Diet}

Bonytail are omnivorous, feeding on a variety of insects, plants, and fish. Smaller individuals were observed chasing large zooplankton and insects near the surface of CHLP at night. Larger adults complement their diet with crayfish, frogs, and fish (McDonald and Dotson, 1960; Marsh and Schooley, 2004). Vanicek (1967) reported they fed on terrestrial insects during the summer, primarily adult beetles and grasshoppers.

The stomach contents of 72 bonytail collected from CHLP at dusk and dawn were examined. Only $7 \%$ of the fish examined at dawn had empty stomachs compared to $33 \%$ of those examined at dusk, suggesting the fish fed primarily at night. Stomachs contained invertebrates (dipterians, copepods, amphipods, decapods, and odonates) are slightly less plant material; $8 \%$ contained crayfish or fish remains (fig. 20). The 


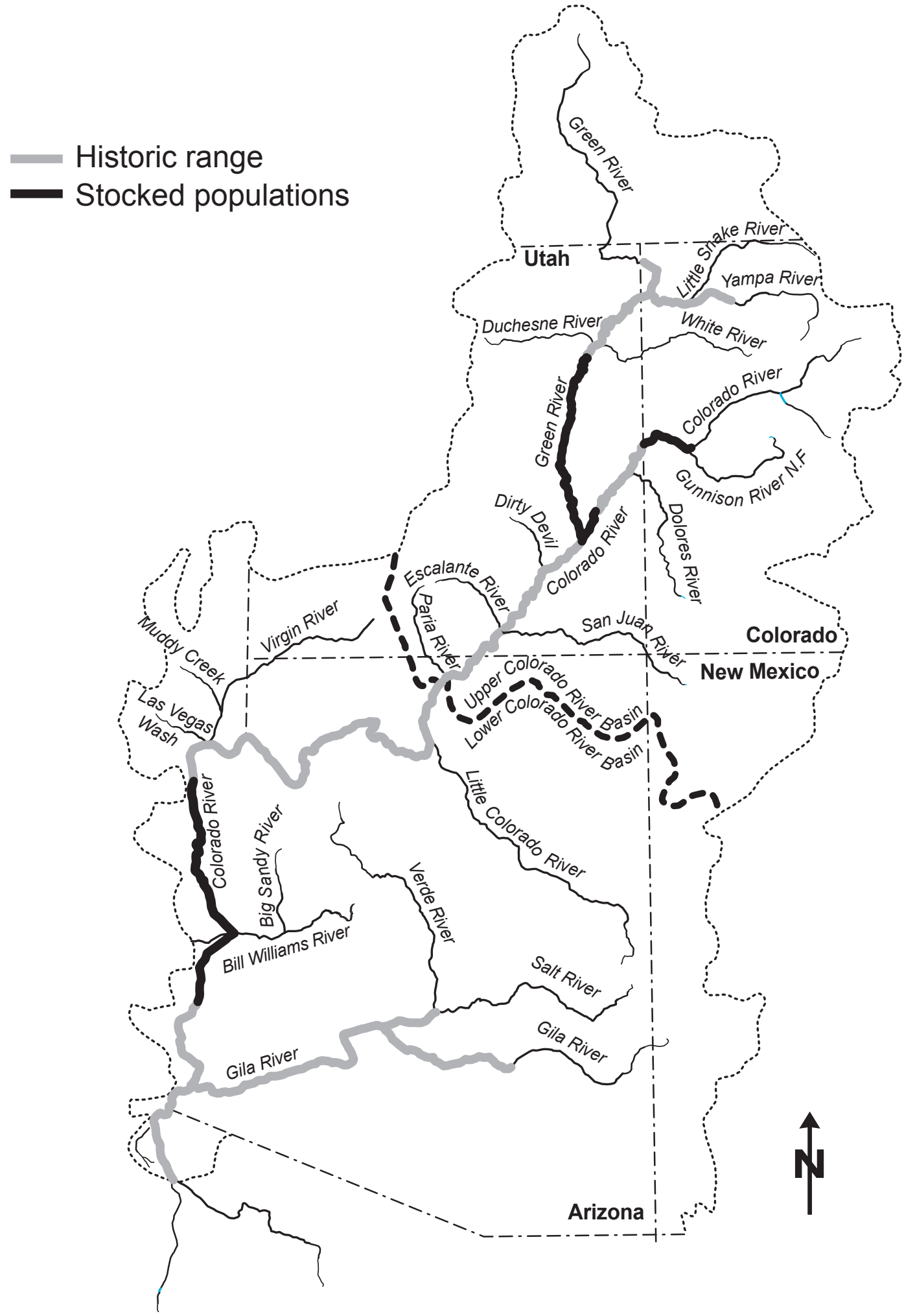

Fig. 19. Historical and current distribution of bonytail in the Colorado River Basin. 


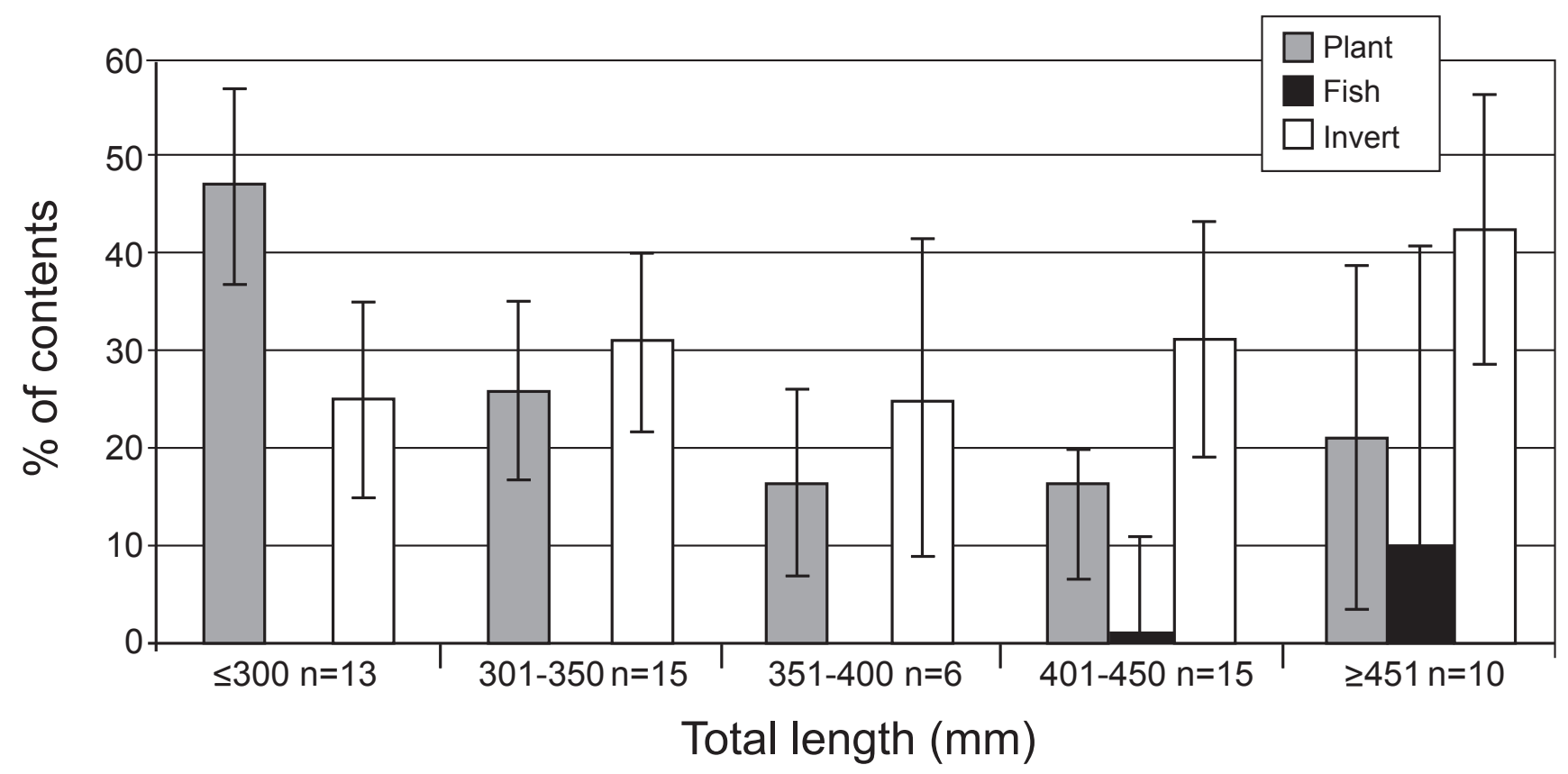

Fig. 20. Bonytail stomach contents by 50-mm size class, Cibola High Levee Pond, Arizona-California, 2003-2004. Fish with empty stomachs were excluded from the analysis. Courtesy of Paul Marsh, Arizona State University.

general trend suggests the percentage of plant material eaten decreases as fish grow, while the percentage of invertebrates and fish material increases with size, especially for fish $>40$ $\mathrm{cm}$. Underwater videos showed fish taking live crayfish and cannibalizing recently spawned eggs.

Their omnivorous diet is substantiated by angler reports. W.P. Blake (1864) sketched the perfect likeness of a bonytail in his 1864 journal and reported capturing several on lettuce.

\section{Parasites}

External parasites have rarely been observed on fish from CHLP. Anchor worms (Lernea spp.) have been reported (Hagan and Banks, 1963; Vanicek, 1967) but they have not been observed on CHLP fish. However, 24\% $(n=25)$ of the fish examined from CHLP were infested with the Asian tapeworm (Bothriocephalus acheilognathi) (Marsh and Schooley, 2004).

\section{Age-Length Distribution}

Growth rates are dependent upon numerous variables; the most notable are temperature, diet, space, and stress. Cibola High Levee Pond bonytail had greater growth during their initial years compared to fish raised at Dexter NFHTC. Pond fish grew nearly twice as fast during their first 2 years (fig. 21). Hatchery fish are typically separated in holding ponds as they become larger, and growth differences between the two locations at age 4 is an artifact of hatchery practices.

\section{Longevity}

Vanicek and Kramer (1969) examined scales taken from 67 bonytail captured in the Green River and determined the maximum age of $<40-\mathrm{cm}$ fish was 7 years. More recent studies suggest that common aging methods for long-lived fish are often inaccurate. Outlying annuali of older ( $>5-6$ years) fish become crowded and difficult, if not impossible, to read (Marsh, 1997b; Hawkins and others, 2004). There is ample evidence the species' longevity can exceed 30 years of age.

Marsh (1997a) examined the otoliths of 17 bonytail captured from Lake Mohave during 1992, 1993, and 1995. Ages of both males ( $n=9,47.7+1.8$ [SD] $\mathrm{cm}$ total length [TL]) and females ( $n=9,49.1+3.8 \mathrm{~cm} \mathrm{TL})$ ranged from 7 to 13 years old. Lengths of these fish were quite similar to museum specimens of wild fish, suggesting that age estimation becomes less reliable as fish become older.

Accurate aging techniques do not exist for these fish at this time, but all evidence suggests that the natural recruitment phenomenon that McCarthy and Minckley (1987) described for razorback sucker also occurred in bonytail. When the dam was closed in 1954, resident fish trapped in the reservoir

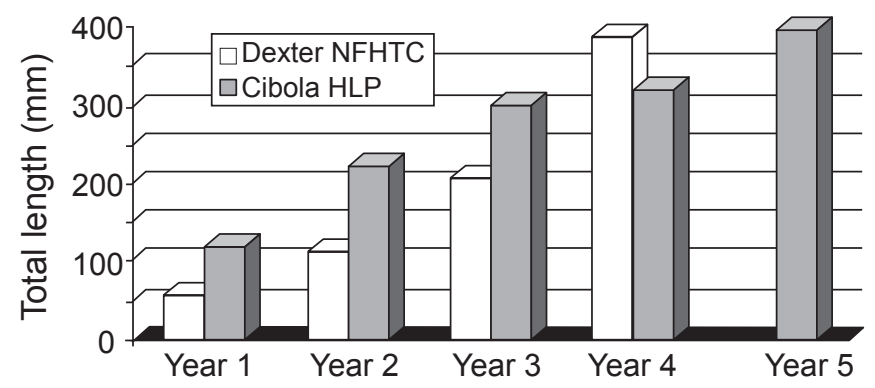

Fig. 21. Average length $(\mathrm{mm})$ of bonytail growth of known ages at CHLP and Dexter NFHTC. Fish growth at CHLP was determined from scales $(n=76)$. 
successfully spawned before the new reservoir was filled with nonnative fishes. Wild bonytail continued to be captured into the mid-1990's, suggesting these fish were nearly 40 years old. Rinne and others (1986) suspected one Lake Mohave bonytail had reached 49 years of age.

\section{Habitats and Habits}

Early scientists believed that bonytail inhabited or preferred swift waters due to their body morphology. La Rivers (1962) suggested their bodies had "reduced squamation to decrease water resistance, greater streamlining and more powerful fins to make propulsion a more effective process, and head dorsum concavity to aid the animal in steadying itself on the bottom against strong currents."

While these fish may have been capable of dealing with swift currents, Minckley (ASU, oral commun., 1998) believed the nucleus or sanctuary population emanated from the vast wetland expanses the Colorado delta region, as it did for the razorback sucker. Unfortunately, an estimated 1.9 million acres of this habitat were drained and lost to agricultural development (Mueller and Marsh, 2002). The vast expanse of nursery and rearing habitat was fragmented and lost by water and land development.

Vanicek and Kramer (1969) and others stressed bonytail were never captured in swift currents, but rather were found in slack water near eddy-lines (Valdez and Clemmer, 1982). Crowl and others (2000) reported bonytail preferred mild velocities $(0.06 \mathrm{~m} / \mathrm{s})$ and selected areas close to cover where they could conceal themselves in laboratory tanks. Badame and Hudson (2003) reported that small $(10 \mathrm{~cm})$ hatcherystocked bonytail were normally found in flooded tributaries, and Pimental and Bulkley (1983) reported that adults occasionally sought refuge in turbid water in laboratory experiments. Intermediate sized $(10-35 \mathrm{~cm})$ bonytail were observed by the author swimming in close proximity to submerged vegetation. Any threatening movement would cause the fish to immediately swim into cover.

Tom Burke (BOR, oral commun., 2005) gave an account of a large floating mat of vegetation that was located in a bonytail rearing pond adjacent to Lake Mohave. The floating mat moved in response to prevailing winds. Attempts to seine bonytail failed to produce any fish, leading biologists to believe that the fish possibly had died of natural causes. Fish were eventually captured when someone inadvertently waded through the vegetative mat, causing bonytail to leave their effective hideaway.

Cover is an important attribute for all life stages of bonytail. The genus Gila is remarkably adaptive to a wide range of physical habitat conditions, but all three Gila species ( $G$. cypha, G. robusta, G. elegans) exhibit a strong fidelity to dark cover, whether it be in the form of bank cavities, root wads, drift piles, or large rock talus (Valdez and Ryel, 1997; Marsh, 2004b). We found a high degree of fidelity toward riprap bank cavities (i.e., talus) at CHLP. These cavities were used exclusively during daylight hours (Marsh, 2004b). Crowl and others (2000) reported that juvenile bonytail preferred any substrate that was large enough to conceal them, suggesting that cavity size may have been a contributing factor in individual site selection in the laboratory.

\section{Beaver Association}

Research has shown that beaver can greatly influence fish communities by the alteration of physical habitat (Snodgrass and Meffe, 1998; Schlosser and Kallemeyn, 2000). Prior to settlement, beaver were widespread and abundant in the Lower Basin floodplain (James, 1906). Pattie (1831) reported beaver trapping was exceptionally good downstream of the confluence of the Gila River. Taking 50-60 beaver a night was a common occurrence. That number suggests they would have had a major influence on the floodplain's landscape.

Small bonytail were routinely found in the entrances of flooded beaver dens at CHLP (fig. 22). In addition, beaver activity along the shallows of the shoreline provided cleaned gravels where fish spawned. These interactions suggest bonytail had a commensal relationship with beaver.

Beaver colonize the more secure, off-channel oxbow and meandering habitats, providing aquatic habitats with additional depth, water volume, and conditions where food items such as invertebrates, insects, plankton, and vegetation thrive. Ponds may have served as nurseries and grow-out areas for young. Bank dens, lodges, and woody debris provided bonytail cover, and dams may have actually provided barriers for large Colorado pikeminnow. This could have been historically important for off-channel habitats that were isolated for extended periods of time.

\section{Movement}

There is little information available regarding the movement of wild bonytail. Historically, large numbers of bonytail were stranded by irrigation diversions, which suggests there

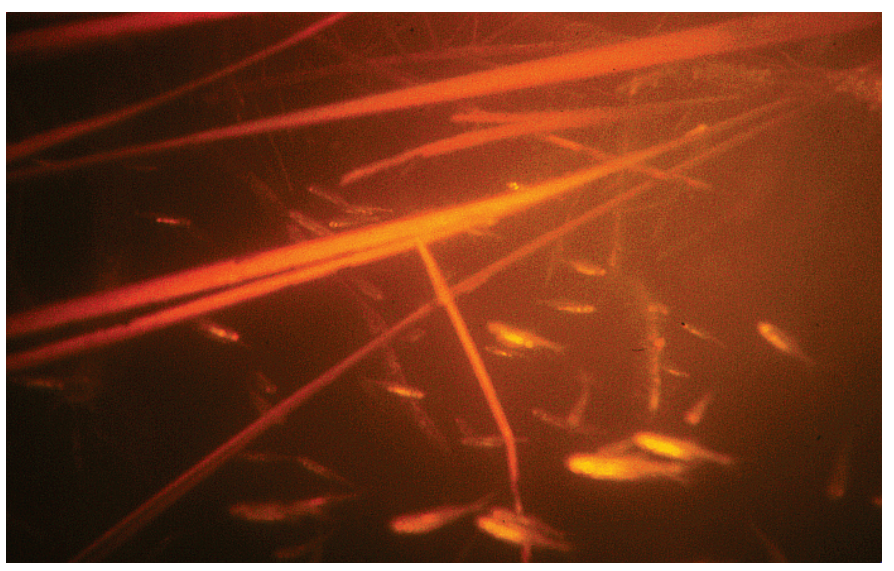

Fig. 22. A school of small $(>5 \mathrm{~cm})$ bonytail found inside the entrance of a beaver den at Cibola High Levee Pond. Fish are approximately 2 to $5 \mathrm{~cm}$ in length. 
were occasional downstream movements (Miller, 1961; Mueller and Marsh, 2002). Reservoir residents (hatchery stocked) exhibited daily movements of as much as $10 \mathrm{~km}$ during spawning season as they moved from deeper to shallower habitats at night (Marsh and Mueller, 1999). Badame and Hudson (2003) reported similar movement in the Green River as fish moved closer to the shoreline at night and tended to move downstream.

There is little evidence to suggest that bonytail migrated any significant distance to spawn. Their behavior appears similar to the humpback chub (Gila cypha), which remain in relatively small geographical reaches (Valdez and Clemmer, 1982; Valdez and Ryel, 1997). However, depending on the availability and placement of cover and spawning habitats, Lake Mohave bonytails moved as much as $10 \mathrm{~km} /$ day between preferred canyon habitats and suspected spawning areas. Displaced bonytail traveled as much as $14 \mathrm{~km} /$ day $(41 \mathrm{~km} / 3$ day) to return to sites from where they were captured (Mueller and Marsh, 1998).

\section{Reproduction}

Roger Hamman (USFWS, oral commun., 2005) reported that volunteer spawn was common for fish 2 years old or older. Fish apparently mature as soon as their first or second year of life. We found $10-\mathrm{cm}$ females expressing eggs, and similarly sized females were reported by Bradwisch (UDNR, oral commun., 2005) to contain up to $20 \%$ of their body weight in eggs (fig. 23).

The ventral fins and belly of both sexes turn golden red during spawning (Vanicek, 1967) (fig. 24). Males become tuberculated on their heads, anal, pelvic, and caudal fins; tuberculation is rarely found on females. Their genitalia are relatively small but are distinguishable. The egg vent on large females swells during spawning season, causing the structure to protrude noticeably. The male organ (Vas deferens vent) is small but can be exposed by applying pressure just anterior to the vent (fig. 25). This extends the Vas deferens which forms a small, white triangular flap that covers the vent.

Spawning occurred in early March and April at CHLP, in May at Lake Mohave, and as late as early July in the upper

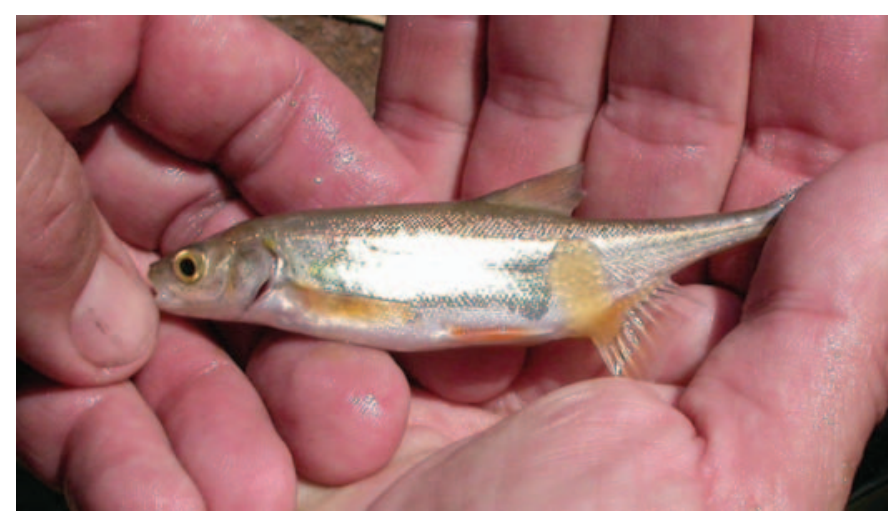

Fig. 23. A small bonytail female freely expressing eggs taken from Cibola High Levee Pond, Arizona-California.

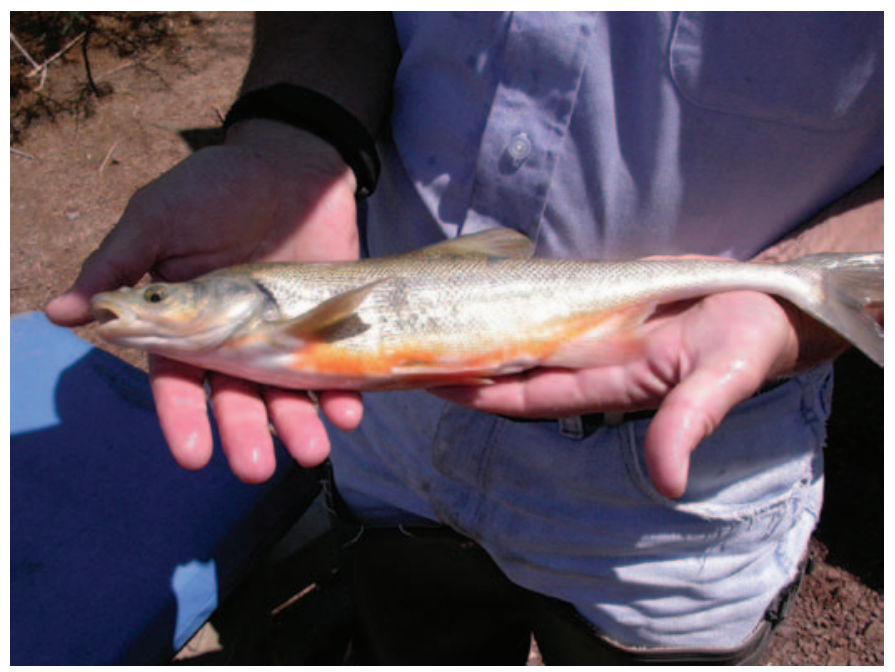

Fig. 24. Ripe male bonytail with sexually pigmented coloration (orange-red) on its cheeks, belly, and lower fins.

Green River (Jonez and Sumner, 1954; Vanicek and Kramer, 1969) (fig. 26). The commonality of these events appears to be similar water temperature $\left(18-20^{\circ} \mathrm{C}\right)$, and the fact that spawning moved upstream as the river warmed. Spawning at CHLP occurred in early to mid-April in 2002 and 2003 but occurred 1 month (March 10) earlier in 2004, due to unseasonably warm temperatures. Water temperatures in all instances had reached $18^{\circ} \mathrm{C}$. Spring runoff has a cooling and delaying effect for fish found in upstream reaches of the basin. The collection of small fish $(<4 \mathrm{~cm})$ at CHLP suggests that late summer spawning may have occurred, which is not uncommon with other desert fishes (Mueller, 1984; Douglas and others, 2000).

\section{Spawning Site Selection}

Normal spawning under "natural" conditions has never been described, due to the rarity of the species and the altered state of the river. The only description was provided by Jonez

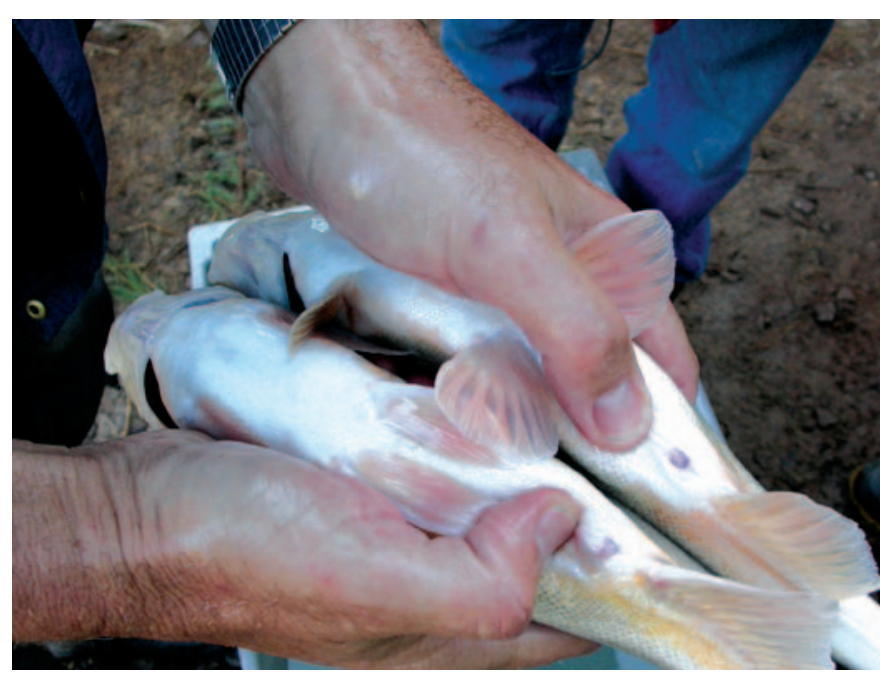

Fig. 25. Sexual characteristics of female (left) and male (right) bonytail are limited to slight differences in their genital morphology. 


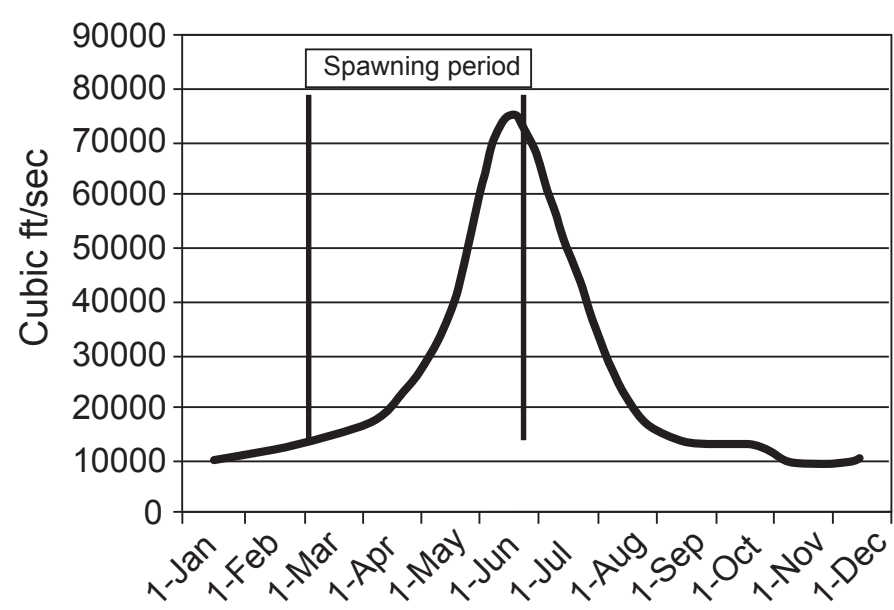

Fig. 26. Hydrograph for the Colorado River at Yuma, Arizona (1904-1934). Bonytail spawning can start as early as March in the Lower Basin and extend upstream until mid-July.

and Sumner (1954), as they observed about 500 bonytail spawning over a gravel shelf in the newly forming Lake Mohave. Bonytail averaging 28 to $34 \mathrm{~cm}$ in length spawned at depths to $10 \mathrm{~m}$. Each female was attended by three to five males. Small $(1 \mathrm{~mm})$ eggs were broadcast over the gravels.

Marsh and Mueller (1999) suspected spawning in Lake Mohave by the diel movements of adults that were carrying sonic transmitters. Bonytail moved from the deeper confines of canyons they inhabited during the day to shallow rocky points where they were suspected to be spawning at night. Using a spotlight at night, three bonytail were observed off a rocky shoreline where they were believed to be spawning. Bonytails were observed spawning in CHLP during 2002, 2003, and 2004. Spawning occurred adjacent to shore along the river levee at a depth $<0.5 \mathrm{~m}$ and involved several dozen small $(10-20 \mathrm{~cm})$ fish.

Fish eggs were found at two other locations in similar habitats. Spawning sites share three commonalities. First, the substrates were clean; second, substrates were relatively uniform in size, ranging from $2-4 \mathrm{~cm}$; and third, all sites were adjacent to deeper water. The substrate types and proximity to depth appear common to all reported sightings (Jonez and Sumner, 1954; Marsh and Mueller, 1999).

Bonytail can successfully spawn on clean substrates other than large gravels. Volunteer reproduction is commonplace in hatcheries and rearing ponds where bonytail are held. Culturists (Quent Bradwisch, UDNR; Chester Figuel, USFWS; Manuel Ulibarri, USFWS; oral commun., 2005) report that successful reproduction occurs in plastic-lined or mud ponds where bonytail spawn on screens, metal drain buckets, clean concrete, and evaporative cooler pads floating in the water column. Mitch Thorsen (USFWS, oral commun., 2003) observed bonytail spawning on flooded gravel of the boat landing area at CHLP.

\section{Spawning Behavior}

Spawning was observed during both day and night at CHLP, which also seemed the case in Lake Mohave (Jonez and Sumner, 1954: Marsh and Mueller, 1999). Spawning involves a great deal of social interaction of similarly sized fish intermingling in tight schools. Small $(10-15 \mathrm{~cm})$ individuals were by far more common, but larger $(>30 \mathrm{~cm})$ bonytail were also active in the area at night.

Bonytail concentrated over the actual spawning area where interaction involved chasing and nudging, with males attempting to coax females to spawn. Willing females would be bracketed by several males, and the group would glide to the substrate. Both sexes would arch their backs, angling their genitalia together and spasm as gametes were expelled. Rapid finning would flush their fertilized eggs into the interspaces of the substrate. The actual process was rapid, taking only 1-3 seconds to complete.

Spawning activities were so intense at times that a sure sign that fish had actually mated came from the evident feeding frenzies that followed. Bonytail not actively spawning would aggressively drive their snouts into the gravels, attempting to feed on eggs. This would last for several seconds $(>10)$ until eggs were probably no longer available. Eggs were found adhered to the sides and bottom of larger material, and their distribution and abundance suggested the majority of spawning occurred in the shallows $(<1 \mathrm{~m})$ (fig. 27). Spawning was only observed along the river levee on a relatively small $\left(1 \mathrm{~m}^{2}\right)$ area of large gravel that recently had been disturbed by beaver.

\section{General Behavior}

Emerging young are small $(6-8 \mathrm{~mm})$. Larvae are phototactic (Muth and Haynes, 1984; Snyder and Meismer, 1997) and were captured using floating light traps. Young were

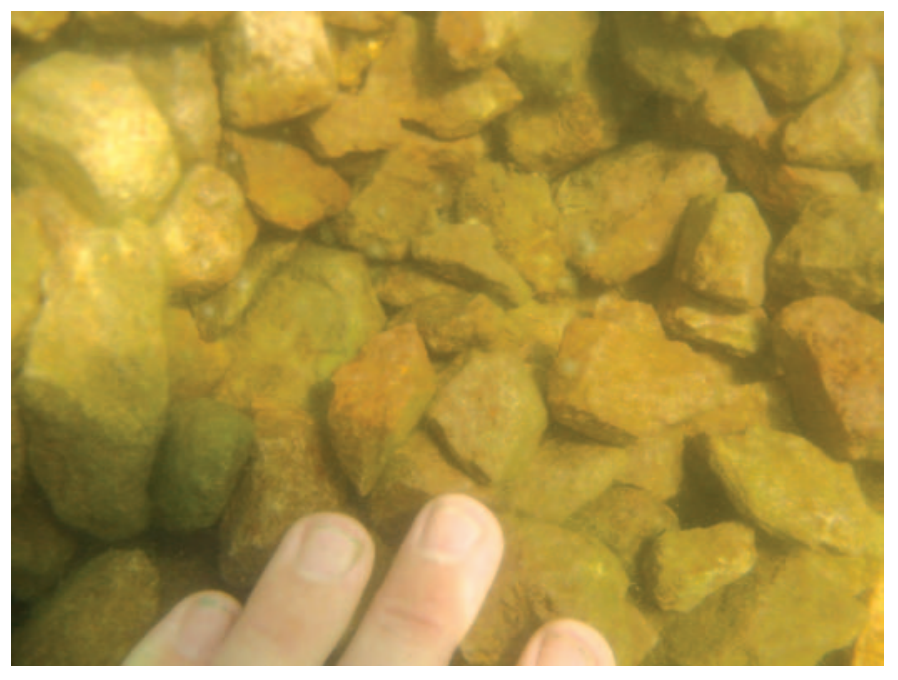

Fig. 27. Bonytail spawning site located on the terminus of a beaver trail on the river levee. Activity on the trail created a bed of smaller sized rocks that was used by spawners. The material was uniform in size, ranging from $2-5 \mathrm{~cm}$ in diameter. Note some fungused eggs. 
found among swarms of large zooplankton and small water boatmen (Corixidae). Groups seldom numbered more than a dozen fish, which were found hiding along shore under floating vegetation and in submerged brush and vegetation.

\section{Fry and Juveniles $(<10 \mathrm{~cm})$}

Fry and juveniles $(15-100 \mathrm{~mm})$ gathered to form larger schools that numbered in the hundreds of individuals at CHLP. During daylight, small $(<5 \mathrm{~cm})$ fish were found in submerged brush and under cut banks, and were most commonly found in the cavities of beaver den entrances. They preferred dark cavities with sufficient depth that allowed them to distance themselves from relentless crayfish.

Bonytails are typically nocturnal (fig. 28) and disperse through the water column, feeding on or near the surface. Occasionally, small, tight schools were observed in the shallows during the day and, when disturbed, would respond quickly in a frenzy of activity. However, they appeared to avoid direct sunlight and were repelled by light at night.

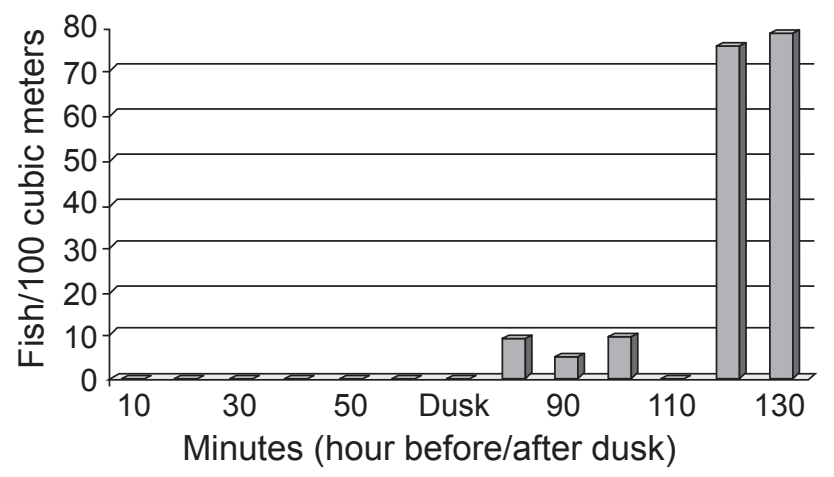

Fig. 28. Fish activity at Cibola High Levee Pond was measured approximately 1 hour before until 1 hour after sunset using a scientific echosounder. This device detects and measures fish densities $\left(\mathrm{fish} / \mathrm{m}^{3}\right)$. Graph shows mean fish densities per 10 minutes of monitoring for a $2+$ hour period starting 70 minutes prior to and continuing for 70 minutes after sunset.

\section{Adults $(>10 \mathrm{~cm})$}

Bonytail become more secretive with age, utilizing more complex, darker cover during daytime. Ten- to $15-\mathrm{cm}$ fish were found in submerged tumbleweed mats located in the deeper portions of the pond. Larger adults were reclusive and, when observed, darted between dense stands of submergent vegetation. Possibly the shallow nature of the pond and avian predation made fish more timid. Historically, small schools of adults ( $>30$ $\mathrm{cm}$ ) were reported swimming in Lake Mead and Lake Mohave (Moffett, 1943; Jonez and Sumner, 1954). We've documented similar schooling of smaller fish $(<15 \mathrm{~cm})$, but schools of larger fish ( $>15 \mathrm{~cm}$ ) were detected (underwater video) only at night.

Bonytail avoid predators by seeking cover or forming tight schools when disturbed (Manuel Ulibarri, USFWS, oral commun., 2004). Fish exhibit a unique startle defense that Chester Figiel (USFWS) termed as "scrumming," after the rugby term. Fish form a tight ball with their heads aligned toward the center while they beat their tails rapidly (fig. 29). The frenzy is believed to be a defensive behavior designed to startle predators. We observed this common hatchery behavior twice at CHLP.

Bonytail are easily captured from rearing ponds using recreational angling equipment. However, once a fish is hooked, it then becomes difficult to capture others, suggesting the fish may release fright pheromones (Quent Bradwisch, UDNR, oral commun., 2004).

The species seems to be quite intelligent and skillful in avoiding some types of nets. For instance, the majority (>80\%) of bonytail that were captured in hoop nets or fish traps had accidentally gilled themselves in the netting rather than being trapped in the net's chamber. These fish were normally found near the float or lead line, apparently trying to go over or under the barrier. Researchers believe they can easily find their way out of most fish traps set in standing water. Anyone who has worked with bonytail has undoubtedly experienced their ability to leap from floating live pens.

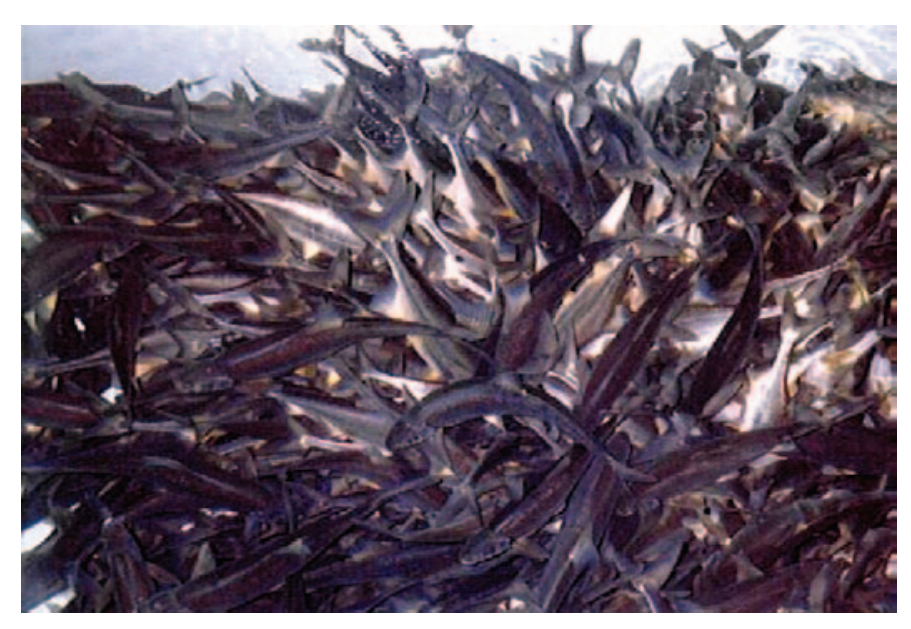

Fig. 29. Startled bonytail exhibiting a cooperative fright behavior where fish align with their heads toward the center of a tight ball and beat their tails frantically. Hatchery personnel has termed this behavior "scrumming." Photo courtesy of Chester Figiel, 2004, U.S. Fish and Wildlife Service.

\section{Razorback Sucker Life History}

A great deal of knowledge is available on the razorback sucker, especially the description of their decline, aspects of adult ecology, and the results of stocking programs. However, there is little information pertaining to early life stages, because the nearly complete disappearance of young wild fish occurred before they could be studied by scientists.

W.L. Minckley was a principal contributor to the existing pool of knowledge (Minckley, 1973, 1983; Minckley and others, 1991). His book, Battle Against Extinction (Minckley and Deacon, 1991) and his 1983 paper provide the most comprehensive description of this species and its plight. Other 
notable sources of information include Tyus (1987), Bestgen (1990) and the USFWS Razorback Sucker Recovery Plan (1998a) and Recovery Goals (2002b).

\section{Physical Description}

The razorback sucker is the largest of the Colorado River suckers (figs. 30, 31, 32). It is strong muscled, yet docile to handle. Adults have a well-developed dorsal keel, a subdorsal mouth with large fleshy lips, and a beautifully colored body. Minckley (1973) describes the fish thus: "Head and body elongated. A sharp-edged keel developed in adults behind occiput, supported by greatly produced, underlying bones. Lateral-line scales moderately small, 68 to 87 in number; scales often absent from, or deeply embedded in skin of anterior margin of predorsal keel. Dorsal fin relatively long, with 13 to 16 , usually 14 or 15 , fin rays. Gill rakers slender and numerous, 44 to 50 on the first arch. Color olivaceous to brownish-black above, lighter below (often yellow). Sides with brown or pinkish to reddish-brown stripes. Dorsal fins dark; anal fins yellow; caudal fin light yellow-brown. Breeding males black or dark brown on dorsum and upper sides, orange laterally, and bright

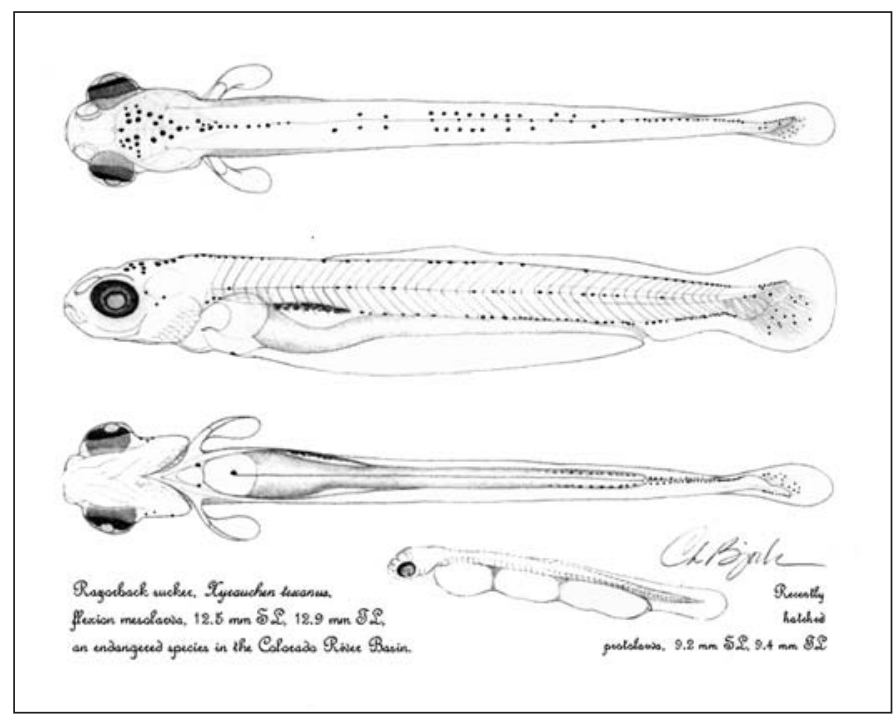

Fig. 30. Drawings of razorback sucker larvae. Drawing courtesy of Darrel Snyder (Snyder 1981), Colorado State University, Fort Collins.

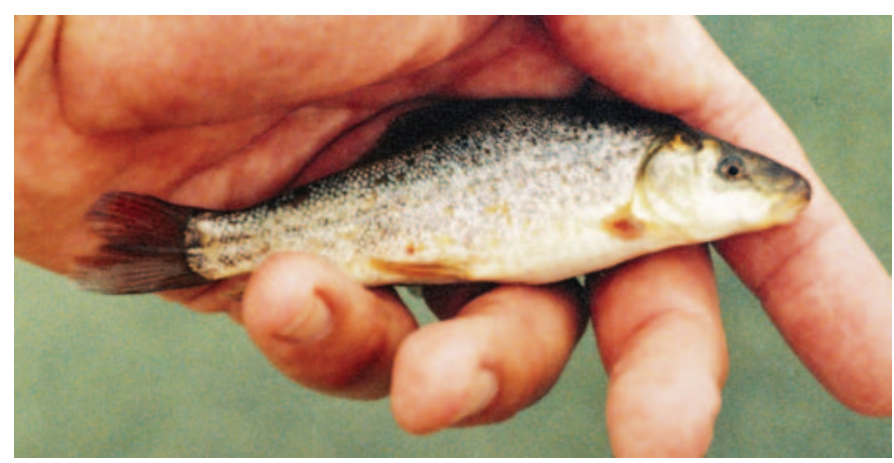

Fig. 31. A juvenile razorback sucker about $10 \mathrm{~cm}$ in total length.

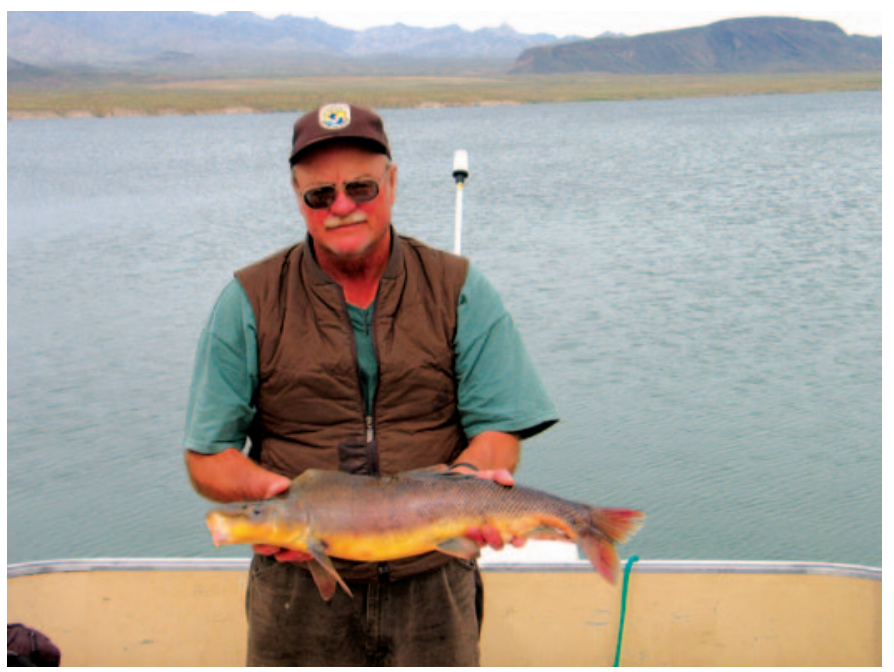

Fig. 32. C.0. Minckley holding a repatriated razorback sucker collected from Lake Mohave in 2004. Photo courtesy of Chuck Minckley, U.S. Fish and Wildlife Service.

yellow on belly. .. (fish) sometimes reached lengths approaching a meter and weights of 5 to $6 \mathrm{~kg}$ " (p. 154).

The bony dorsal keel is absent in young fish (fig. 31) and develops as the fish grows (fig. 32). For years the keel was presumed to aid the fish hydrodynamically, but recently it has been suggested it may be a predator-defense structure that reduces the likelihood of being swallowed by Colorado pikeminnow (Portz and Tyus, 2004).

\section{Sexual Dimorphism}

Minckley (1983) suggested there were six, possibly seven, sexually dimorphic characteristics for the species. Sexual coloration and tuberculation are only apparent during their reproductive cycle (November to April). Males are typically dark-olivaceous to black dorsally and have a bright orange belly. Females usually have a lighter-colored belly (Douglas, 1952; Minckley, 1973). Tuberculation is found on both sexes but is much more prominent and widespread in males. Male tubercles are large and often extend below the lateral line to include the pectoral and anal fins, fully covering the lower portion of the caudal peduncle. Female tubercules are smaller and rarely extend beyond the lower lobe of the caudal fin and anal fins.

The five remaining criteria involve (1) body length and weight, (2) pelvic fin length, (3) anal fin length, (4) urogenital papillae, length, and morphology, and (5) curvature of the last anal fin-ray in males (the ray remains straight in females) (fig. 33) (McAda and Wydoski, 1980). Minckley's (1983) comparison of the sexual dimorphism of Lake Mohave fish showed that females were nearly $17 \%$ longer and weighed $45 \%$ more than males. Length of male pelvic and anal fins was approximately $25 \%$ longer compared to those of females. Lastly, the length of female papillus was $43 \%$ longer than males. No measurements of fin-ray curvatures were provided by McAda and Wydoski (1980). 


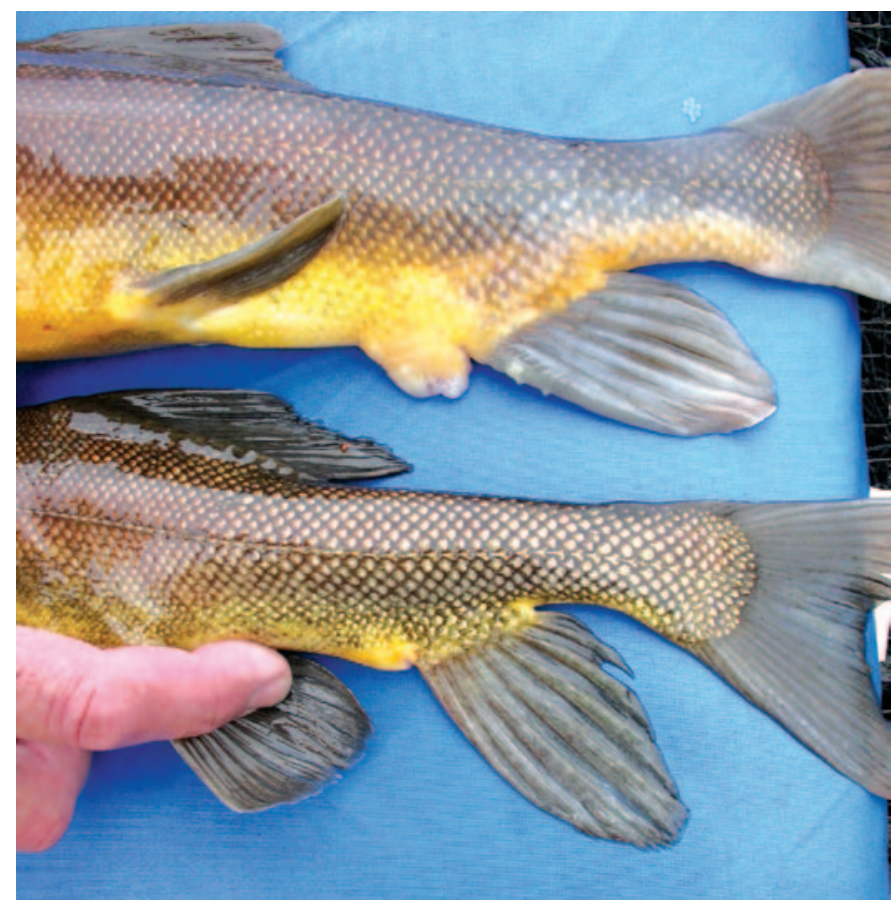

Fig. 33. Photograph showing the sexual characteristics of a razorback sucker female (top) and male (bottom) showing differences in size and shape of their genitalia.

\section{Distribution and Abundance}

\section{Historic Distribution}

Razorback suckers were endemic to the Colorado River and its major tributaries. Their range extended from the Colorado River delta upstream to major tributaries found in Arizona, Utah, Wyoming, New Mexico, and Colorado (Jordan and Evermann, 1896; Maddux and others, 1993; Mueller and Marsh, 1995) (fig. 34). A notation from John C. Fremont's journal suggests "buffalo fish" (razorback sucker) once extended upstream to Piney River in western Colorado, at an elevation of 2,286 m (7,500 feet) (Spence and Jackson, 1973). They were most common in the broad extensive floodplain wetlands that dominated the Lower Basin.

Razorback sucker were widely distributed in the Colorado River system but their abundance in specific habitats may have been seasonal. Pre- and post-spawning studies of tagged fish indicate some fish can migrate substantial distances between seasonal habitats (Tyus, 1987; Modde and Irving, 1998; Mueller and others, 2000). Historically, settlers reported seeing large spawning migrations in the river and its larger tributaries (Hubbs and Miller, 1953). It is possible these schools were spawning aggregations.

Spawners are typically emaciated after spawning and travel to areas where food is more plentiful to regenerate body reserves. They prefer backwater and off-channel wetlands where water is seasonally warmer and more productive (Tyus, 1987; Valdez and Wick, 1983; Wydoski and Wick, 1998). Today, highly productive areas include the inflow areas of reservoirs (Mueller and others, 2000, 2002; Karp and Mueller, 2002). Grinnell (1914) reported that fish were generally scarce in the river channel but abundant in backwaters where there was abundant food. The river provided a corridor for fish to move between these seasonally important habitats.

\section{Beginning of the End: $1880-1970$}

Razorback suckers were abundant when Europeans settled the river basin. Early reports indicate large numbers of fish were periodically harvested and used as fertilizer or livestock feed (reviewed by Minckley and others [1991]). Common carp, bullheads, and channel catfish were successfully introduced in the late 1880's and were common by 1910 (Grinnell, 1914). Their success was associated with the decline of native fishes by the mid-1930's (Dill, 1944) and by 1960, razorback suckers had become rare in the Lower Basin (Miller, 1961). The last significant numbers of young in the Lower Basin were reported near Laughlin, Nevada, in the early 1950's (Jonez and Sumner, 1954; Miller, 1961).

Reservoir populations experienced a short but intense period of recruitment during initial filling of the impoundments (Minckley and others, 1991). Sizable populations became established in Lake Roosevelt (1911), Lake Mead (1935), Lake Havasu (1938), Lake Mohave (1953), and Senator Wash Reservoir (1966) (Minckley and others, 1991). Adults were commercially harvested in Lake Mead and Saguaro Lake in the late 1940's (Hubbs and Miller, 1953; Mueller and Marsh, 2002). Early accounts of spawning were reported for the Lake Havasu population (Douglas, 1952), but those wild fish had disappeared by 2000 .

\section{0 to Present}

Razorback sucker populations continued to decline in the Upper Basin during this period. Scarcity of adults was noticed in the Gunnison, San Juan, Animas, Yampa, and Lower Duchesne Rivers by the late 1970's (Holden and Stalnaker, 1975; McAda and Wydoski, 1980). The last razorback sucker taken from the Upper Colorado-Gunnison portion of the basin was in 1995 (Chuck McAda, USFWS, oral commun., 2005). The decline of fish was well-documented in the Green River, where Lanigan and Tyus (1989) estimated the Green River population of razorback sucker to be about 1,000 fish. Modde and others (1996) reported a population of approximately 500 fish. A decade later, Bestgen and others (2002) estimated the Green River population at only 300, of which about one third were considered wild and the remainder stocked fish.

Small razorback sucker populations persisted after 1970 in the Las Vegas Bay and Overton Arm portions of Lake Mead (Allan and Roden, 1978), but the Lake Mohave population contained the vast majority of wild fish that remained in the basin (Minckley, 1983). The Lake Mohave population was estimated at 88,000 razorback suckers in 1988, 34 years after the closure of Davis Dam (Marsh and others, 2003). McCarthy and Minckley (1987) reported the majority of suckers 


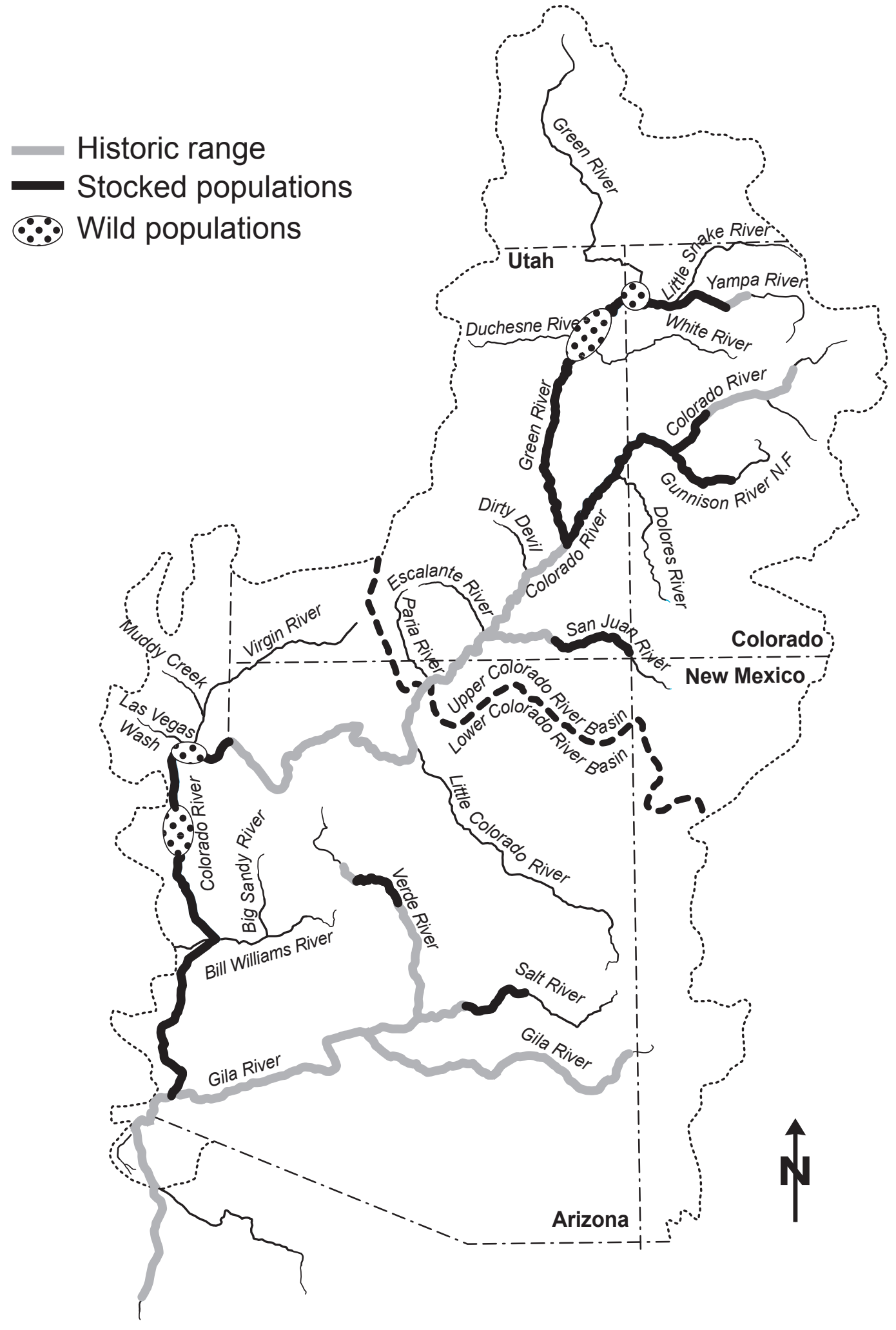

Fig. 34. Historic and current range of stocked and wild populations of razorback sucker (Xyrauchen texanus) in the Colorado River Basin, southwestern United States. 
were hatched or recruited shortly after closure and predicted a catastrophic die-off at the turn of the century. That prediction proved accurate: today, wild fish number $<500$ fish (Paul Marsh, ASU, oral. commun., 2005).

Razorback suckers were rare downstream from Davis Dam by the late 1960's (Marshall, 1976; Kennedy, 1979; Minckley, 1979), and only 42 adults were collected between 1962 and 1988 (Marsh and Minckley, 1989). Marshall (1976) reported capturing two adults in the Topock Gorge area, three were captured in Laughlin Lagoon in 1988 (W. Leibfried, Steve W. Carothers and Associates, oral commun., 1997) and two were observed by the author on a suspected spawning bar just downstream of Davis Dam in 1986. Razorback suckers also were reported spawning upstream of Needles, California. Usage of this site was confirmed in 2005 and 2006 with the presence of several hundred repatriated spawners (R. Wydoski, BOR, oral commun., 2006).

Today, it is estimated that less than 1,000 wild razorback suckers occur in the mainstem Colorado River system. Approximately 500 are found in Lake Mohave, 300 in Lake Mead, and less than 100 in the Green River (Holden and others, 1997; Bestgen and others, 2002; Marsh and others, 2005). It is anticipated that the vast majority of these old individuals will die off during this decade. Although stocking has been going on for 25 years, the number of surviving fish is low. Of the 15 million fish introduced, only a few hundred occur in the Upper Basin (Bestgen and others, 2002; Ryden, 2003a) and approximately 4,000 in Lake Mohave and Lake Havasu (Mueller, 2003; Marsh and others, 2005).

\section{Razorback Sucker Young}

Larval razorback suckers were common for decades. Muth and Wick (1997) collected several hundred from backwaters in Canyonlands National Park and Glen Canyon National Recreation Area. Several thousand have been collected from Lake Mead (Holden and others, 1997; Abate and others, 2002). More than half a million larvae have been collected for culturing purposes from Lake Mohave (Tom Burke, BOR, oral commun., 2005). Reports of larvae further downstream are less common. Marsh discovered 37 larvae among ichthyoplankton samples that were collected from Lake Havasu during 1985 and 1986 (Marsh and Papoulias, 1989). Tom Burke (BOR, oral commun., 1988) reported collecting three larvae at Headgate Dam, and another three were taken from the Central Arizona Canal system, which is a major diversion from Lake Havasu, in 1988 (Mueller, 1990).

The introduction of 30,000 razorback suckers into Lake Havasu successfully reestablished an adult population (Mueller, 2003). These fish now migrate upstream in the Colorado River mainstem to spawn (Mueller, 2003). Dozens of larvae have been captured downstream of suspected and known spawning sites, but juvenile ( $>25 \mathrm{~mm}$ ) have not been collected (Mueller, 2003). Similar stocking efforts have continued downstream of Parker Dam since 1980 (Schooley and Thornbrugh, 2004). Jason Schooley (ASU, oral commun., 2005) reported capturing razorback sucker larvae from two sites in the Palo Verde Division of the Lower River in 2005.

Although larval razorback suckers were commonly collected, juveniles were not, which is symptomatic basinwide. Recent recruitment in the Upper Basin has been limited to a few fish found in the Green River, Utah. Gutermuth and others (1994) reported two juveniles in the lower portion of the Green River, while Modde (1996) reported taking 73 juveniles from Old Charlie Wash in two consecutive years. Unfortunately, Modde's 1996 report represented the total number of razorback young that was found among 10.1 tons of nonnative fish taken from the backwater when it was physically drained. This disparity illustrates the problem: the young razorback suckers have been overwhelmed by large numbers of introduced species.

Juveniles also have occasionally been found in Lower Basin canals or temporary habitats that experience periodical drainage. Christopherson and others (2004) suggested that native survival may be enhanced in habitats that are periodically drained or "reset" by destroying resident predator communities. Young fish, both native and nonnative, that enter these recently inundated habitats would have a better chance for survival than those containing resident predators. Modde and Haines (2005) successfully applied the concept to a natural floodplain depression over two years. Native fish young survived in the absence of predators, or when predators were kept at unnaturally low densities.

Golden and Holden (2003) reported limited recruitment of razorback sucker in Lake Mead. Based on aging studies, they reported finding fish recruitment in 17 of the past 30 years. Survival of young fish was attributed to fluctuations (increases) in reservoir elevation and corresponding increases in protective cover. Unfortunately, recruitment is believed to be inadequate to sustain this population.

Few juvenile razorback suckers were collected prior to 1980 and less than 100 juveniles since 1980. Marsh and Minckley (1989) reported that only 24 documented young $(<37 \mathrm{~cm})$ were captured downstream of Parker Dam between 1974 and 1988. These fish were typically salvaged from irrigation canals during maintenance outages in late fall. Four additional juveniles $(<55 \mathrm{~mm}$ ) were captured from Lake Mohave in 1987 (Marsh and Minckley, 1989). A single fish was collected in 2002 by the Nevada Department of Wildlife (Mike Burrell, Nevada Division of Wildlife, oral commun., 2003). All the juveniles captured in Lake Mohave were in close proximity to Willow Beach NFH and may have been escapees.

\section{Diet}

Wild razorback sucker larvae feed on plankton and benthic organisms their entire life. A larva taken from Cibola High Levee Pond had nearly two dozen cladocerans in its gut (fig. 35). Langhorst and Marsh (1986) reported a high frequency (30-75\%) of empty stomachs in larvae, with the most common dietary organisms in stomachs composed of 


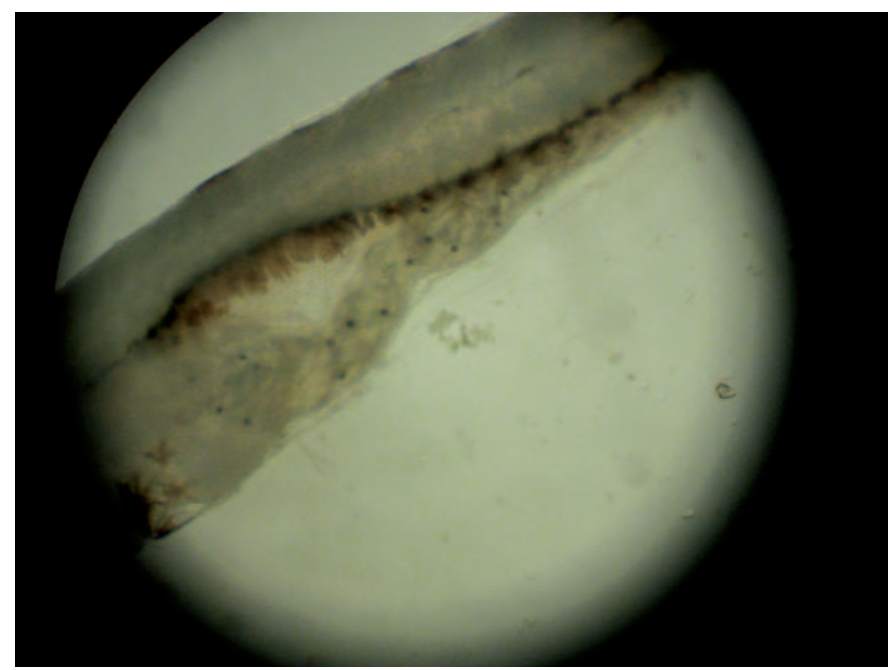

Fig. 35. The abdominal area of a razorback sucker larvae showing its gut filled with about two dozen cladocerans (notice the eye spots of the Daphnia).

cladocerans (Bosmina, Daphnia, and Mocrothrix), rotifers, and copepods, all zooplankton typically found in the water column. The exception was Macrothrix, which is associated with vegetation and was attributed to selective feeding (Langhorst and Marsh, 1986). Other food items reported in larvae included chironomids, ostracods, trichopterans, and algae (Marsh and Langhorst, 1988; Snyder and Muth, 1990). Horn (1996) examined nutritional indices of wild larvae from Lake Mohave and found that starvation was an important factor; however, it alone could not account for the absence of recruitment within the population.

The adult diet is composed primarily of larger-sized zooplankton, benthic organisms, and some vegetative material. Marsh (1987a) found that the stomachs of 24 adults taken from Lake Mohave contained (in order of abundance) cladocera $(100 \%)$, diatoms $(88 \%)$, detritus $(56 \%)$, rotifers $(53 \%)$, ostracods (53\%), algae (44\%), and copepods (34\%). Diets of river fish examined contained diatoms, chironomid larvae, trichopterans, dipterans, ephemeropterans, and vegetative debris (Dill, 1944; Banks, 1964; Vanicek, 1967).

Adults in Lake Mohave were observed swimming near the surface where they were suspected of feeding on zooplankton (Burrell, NDOW, oral commun., 1998). In the flowing portions of the upper reservoir, scuba divers commonly saw them in small groups feeding in beds of Cladophora spp. At CHLP, they form tight, elongated schools (>100 individuals) that swim in tight formations, appearing to slurp zooplankton from near the surface (fig. 36). Their large, white, fleshy mouths are highly visible. These schools often swim in graceful circles $(2-3 \mathrm{~m})$ in "donut" formations. This behavior was reportedly observed both day and night. Allan and Roden (1978) observed razorback suckers feeding on plankton that were attracted to floating crappie lights in Lake Mead. Razorback suckers feed either from or on the stems and leaves of aquatic vegetation during the summer when surface water

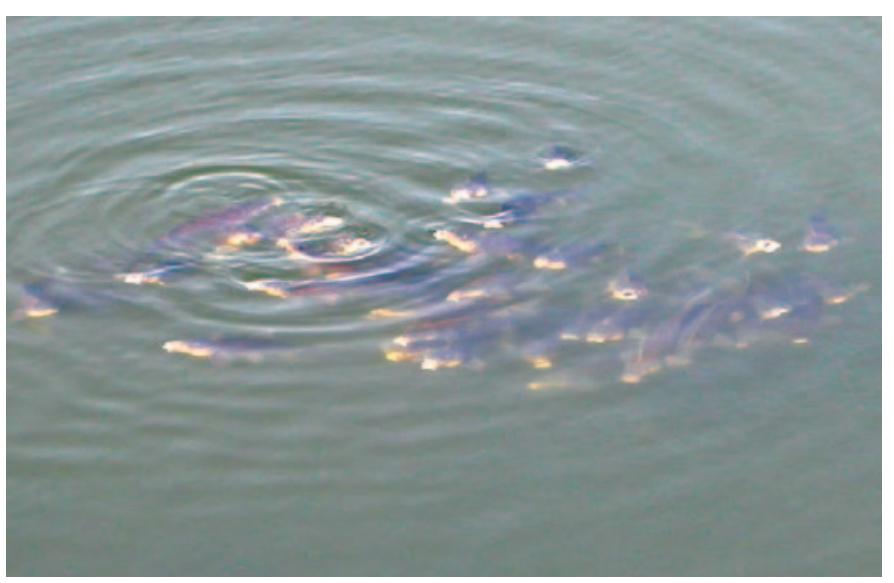

Fig. 36 A school of approximately three dozen adult razorback suckers feeding on zooplankton near the surface of CHLP, Arizona-California. Often schools would contain more than 100 fish that would swim in formation. They appeared to work in unison, forming a "wall of mouths" to herd and feed on zooplankton.

temperatures exceed $35^{\circ} \mathrm{C}$ and large zooplankton communities are depressed. They have been filmed aggressively cannibalizing eggs and feeding among spawning bonytail at CHLP.

Hatchery diets of small suckers 10 to 60 days old consist of Daphnia, brine shrimp, and bloodworms. Larger suckers are fed Silvercup ${ }^{\circledR}$ trout chow at a rate of $1.5-3 \%$ of their body weight per day. The feed is ground for fish $<15 \mathrm{~cm}$ and left pelletized for fish $>15 \mathrm{~cm}$. A greater amount (3\%) is fed at warmer water temperatures $\left(>20^{\circ} \mathrm{C}\right.$ ) (Manuel Ulibarri, USFWS, oral commun., 2004).

\section{Parasites}

Razorback suckers can host a variety of external and internal parasites, none of which are believed to have caused their decline (Flagg, 1982; USFWS, 2002b). The three most obvious external parasites include the anchor worm (Lernaea spp.), numerous leech species, and a pathogenic protozoan (Myxobolus spp.) that can cause blindness in some individuals.

Parasites are typically rare for healthy fish found in optimal habitat conditions. Stressed fish are more susceptible to Lernaea spp. infestations. Netting and electrofishing can lead to subdermal hemorrhaging of the infected area (fig. 37). Heavy infestations of Lernaea spp. (20+/fish) have been reported on fish taken from the San Juan River delta of Lake Powell (Mueller and others, 2001) and from the Verde and Salt Rivers (Creef and Clarkson, 1993; Hendrickson, 1993), suggesting that heavy infestations could contribute to netting mortality, especially during warm summer months.

Minckley (1983) reported a relatively high incidence of disease and parasites for razorback suckers taken from Lake Mohave. He attributed this to the advanced age of the fish. Nearly $12 \%$ of the fish handled were blind in either one or both eyes (fig. 38). The pathogenic protozoan (Myxobolus 


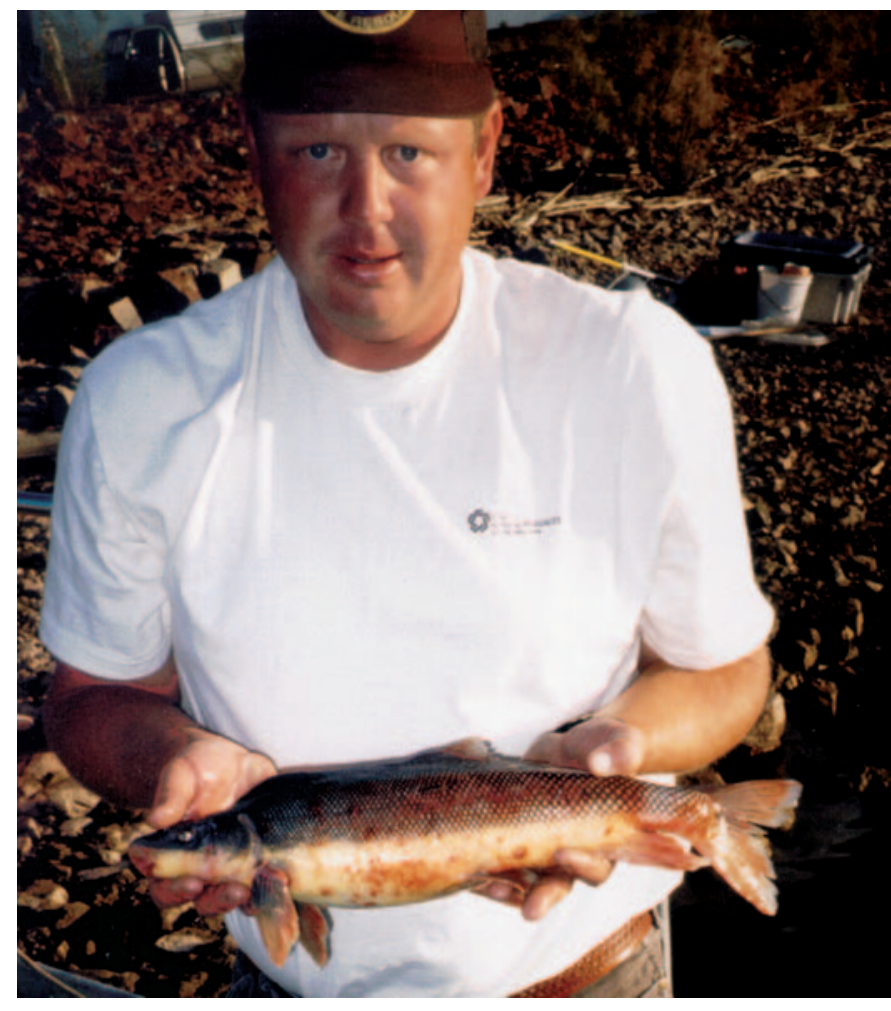

Fig. 37. Quentin Bradwisch (Utah Department of Natural Resources) with a razorback sucker that was captured by trammel net from the San Juan River inflow area of Lake Powell, Utah. The fish was heavily infected with Lernaea spp. That infestation, combined with netting, led to extensive subdermal hemorrhaging.

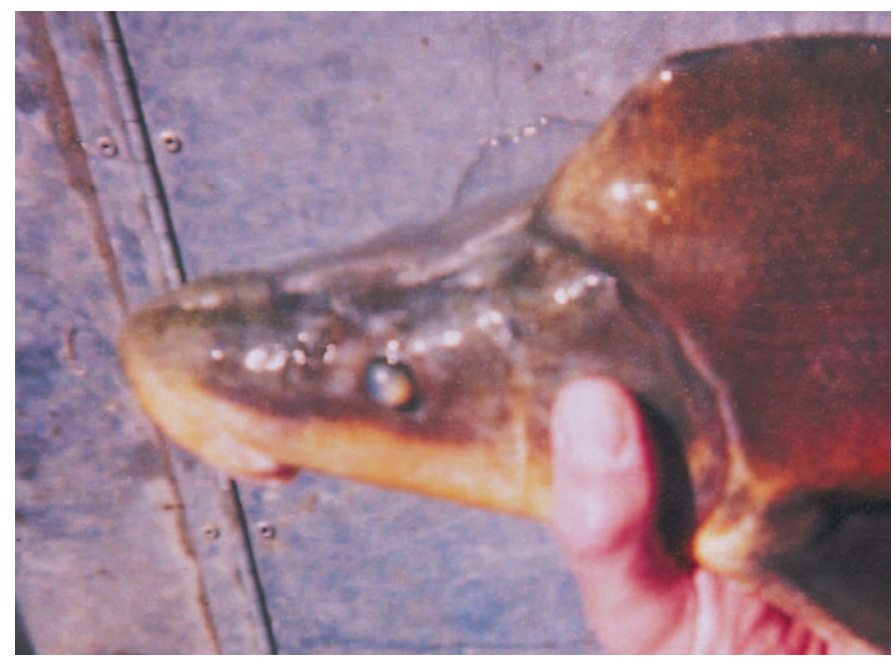

Fig. 38. A high percentage of old razorback suckers were blind in one or both eyes. The afflicted eye often protrudes, lending the term "bubble eye." This condition is believed to be caused by the protozoan, Myxobolus spp.

spp.) was found in samples from several fish. This ailment progresses from opaqueness in the eye to swelling, protrusion, eventual rupture and shrinkage, and gradual dermal growth covering of the orbit (Minckley, 1983).

\section{Age Determination}

Accurate determination of age has been hampered due to slower growth of large fish, in which overlapped or crowded annuali form on normal aging structures (i.e., scales, otoliths, vertebrae, spines) (McCarthy and Minckley, 1987; Hawkins and others, 2004). Otoliths have proven the most reliable bony structure for aging razorback suckers, but fish have to be sacrificed. Abate and others (2002) reported a successful and non-lethal method of aging razorback suckers using pectoral spines.

\section{Age-Length Distribution}

Razorback sucker growth is highly variable and depends upon the length of the growing season, temperature, food availability, space (i.e., stocking density), and the fish's age (USFWS, 2002b). Typically, growth is rapid the first year and declines with age. Sucker growth can vary as much as 5 to 35 $\mathrm{cm}$ their first year (Valdez and others, 1982; Minckley, 1983; Mueller, 1995). Modde and Haines (2005) reported growth ranged from 0.48 to $0.77 \mathrm{~mm} /$ day during their first 160 days of life. Similar growth rates occur in growing ponds in the Lower Basin where growth can be sustained for more than 300 days (34 cm/year).

Likewise, growth can be suppressed naturally or purposely. Hatcheries intentionally limit feed to slow growth for fish that are being held in order to optimize hatchery space and to minimize feeding costs (fig. 39). Overproduction at Rock Tank, located on the Buenos Aries National Wildlife Refuge in Arizona, caused that sucker population to experience natural stunting (Chuck Minckley, USFWS, oral commun., 2004). Growth was retarded, taking fish five years to reach the same length $(30 \mathrm{~cm})$ that could be obtained in one year under more favorable conditions. Razorback suckers were purposely kept small at Wahweap State Hatchery. Year class III fish averaged $115 \mathrm{~mm}$ in length when they were stocked into the Page, Arizona, golf course ponds. Within a year, they had grown to average nearly $358 \mathrm{~mm}$, a tripling of body length (Mueller and Wick, 1998). This illustrates that rapid growth can be resumed if adequate resources are provided.

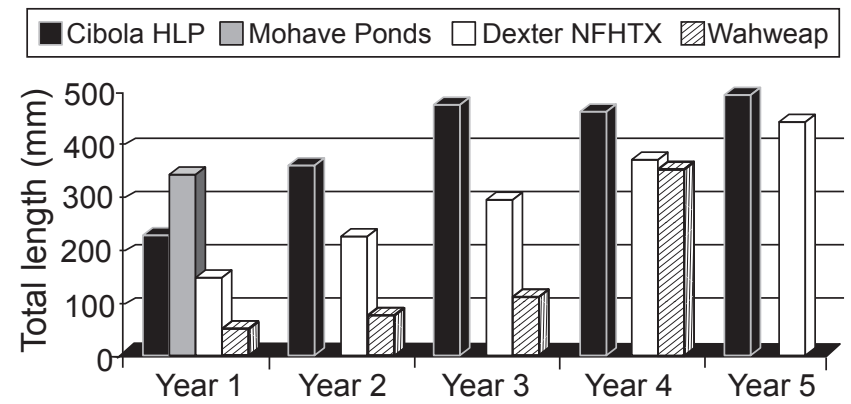

Fig. 39. Comparison of the average length ( $T L=\mathrm{mm})$ of razorback sucker year classes grown under different rearing conditions (Wahweap fish were purposely stunted their first 3 years). 
Growth of razorback sucker in Humphrey's Pond near Grand Junction, Colorado was comparable to fish growth reported in the Lower Colorado River Basin. Juveniles $55 \mathrm{~mm}$ in total length stocked in Humphrey's Pond in June 1987 grew to $307 \mathrm{~mm}$ by November (Osmundson and Kaeding, 1989). These fish reached an average length of $405 \mathrm{~mm}$ by September of the following year and were $462 \mathrm{~mm}$ TL by October 1989 .

Minckley (1983) reported growth rates dropped rapidly for razorback suckers $>45 \mathrm{~cm}$. Lake Mohave suckers that had grown $7 \mathrm{~cm}$ in their seventh year $(\mathrm{TL}=47 \mathrm{~cm})$ grew $<1 \mathrm{~cm}$ the following year. He suggested that by age $12(\mathrm{TL}=52 \mathrm{~cm})$, growth had essentially ceased, especially for males. McAda and Wydoski (1980) and Tyus (1987) reported that growth of the Green River population had declined to $2-3 \mathrm{~mm} / \mathrm{year}$, suggesting the population was composed primarily of large, old fish.

Holden and others (1997) suggested that overall growth could be used to determine the relative age of a population. Their studies on the Lake Mead population indicated that growth based on recapture data was nearly $1 \mathrm{~cm} /$ year, substantially greater than levels measured on relic populations found elsewhere. Aging techniques using pectoral spines suggested younger fish were found in the Lake Mead population (Golden and Holden, 2003).

\section{Longevity}

McCarthy and Minckley (1987) reported that ages of razorback suckers collected in Lake Mohave ranged between 24 and 44 years. They determined that the majority of the reservoir population was recruited within a few years following the filling of the reservoir in 1954. Young suckers were also reported to be abundant just prior to dam closure (Miller, 1961).

McCarthy and Minckley (1987) predicted the Lake Mohave population would crash at the turn of the century. That prediction proved accurate and provides the most compelling evidence that species' longevity can exceed 40, possibly 50 years (Marsh and others, 2003).

\section{Habitats and Habits}

Historically, razorback suckers inhabited nearly 2,000 $\mathrm{km}$ of one of the most physically diverse rivers in the world. Their home extended from the warm, saline estuaries of the Colorado River delta to the cool headwater mountain streams. Initially, they were thought to prefer swift waters due to their unique dorsal keel. While they occur in currents, juveniles, sub-adults, and adults are more commonly found in large and relatively deep pools in the main channel or in backwaters where food and cover are more abundant (Tyus and Karp, 1990; Bradford and Gurtin, 2000; Mueller and others, 2003b). Razorback suckers were commonly seen by divers feeding in beds of Cladophora spp. downstream of Hoover Dam (fig. 40).

Information pertaining to the habitat used by juvenile razorback suckers is limited to observations of hatchery-

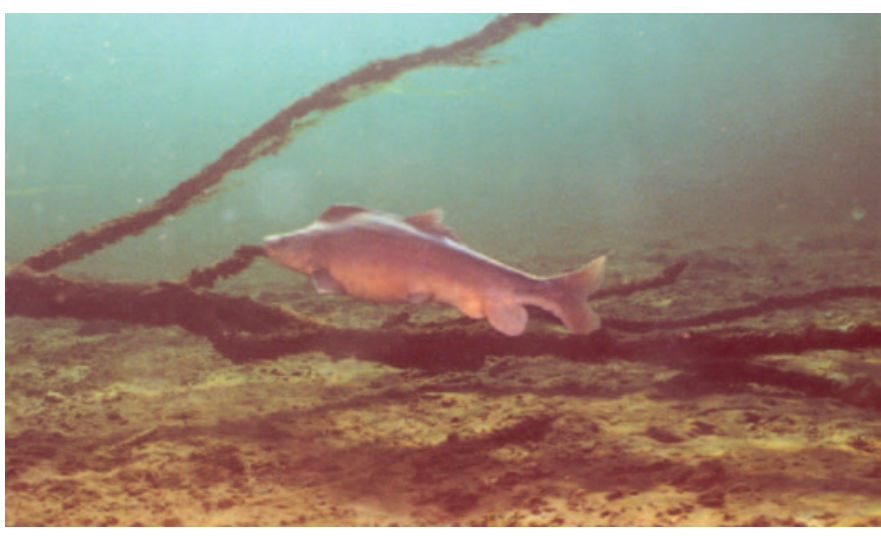

Fig. 40. A razorback sucker located in the main channel of the Colorado River, just downstream of Hoover Dam, Arizona-Nevada. Photo courtesy of Gregory Finnegan, Bureau of Reclamation.

produced fish. They survive exceptionally well in pond environments where predators are absent. They hide in submergent vegetation, brush, and rock talus. Hatchery-reared suckers disperse rapidly when stocked in reservoirs. In rivers, stocked fish typically drift downstream, which may be a symptom of poor physical conditioning due to pond culturing (Mueller and Marsh, 1998; Mueller and Foster, 1999). They normally occupy backwaters and near-shore habitats where they seek cover during daylight hours. They use these refuges continually and only venture away to feed at night (Mueller and Marsh, 1998). Occasionally, fish were observed hiding in the shallows with their heads buried in the vegetation with only their tails protruding (fig. 41).

Large backwaters appear to be just as important to adults as they are to juveniles (Valdez and Wick, 1983; Tyus and Karp, 1990; Wydoski and Wick, 1998). Adults prefer large off-channel backwaters that are generally warmer and support more food organisms such as zooplankton, crustaceans, diatoms, and invertebrates (Wydoski and Wick, 1998; Gurtin and Bradford, 2000). These sites may also be critical for spawners to recover from the vigors of spawning (Wydoski and Wick, 1998).

\section{Movement}

Historically, fish movement was influenced by the seasonal flow regime and their reproductive season. Grinnell (1914) reported few fish in the turbid channel but abundant numbers in the more protected backwaters. Fish undoubtedly found refuge in backwaters during floods when sediment and debris loads were high in the main channel. Likewise, as summer flows receded, larger fish had to retreat to more permanent and deeper habitats that were typically found in scoured portions of the channel and in canyon reaches (Kolb, 1927).

Radio telemetry suggests razorback sucker movement is accelerated prior to and following spawning as fish move between their seasonal and spawning habitats (Tyus and Karp, 


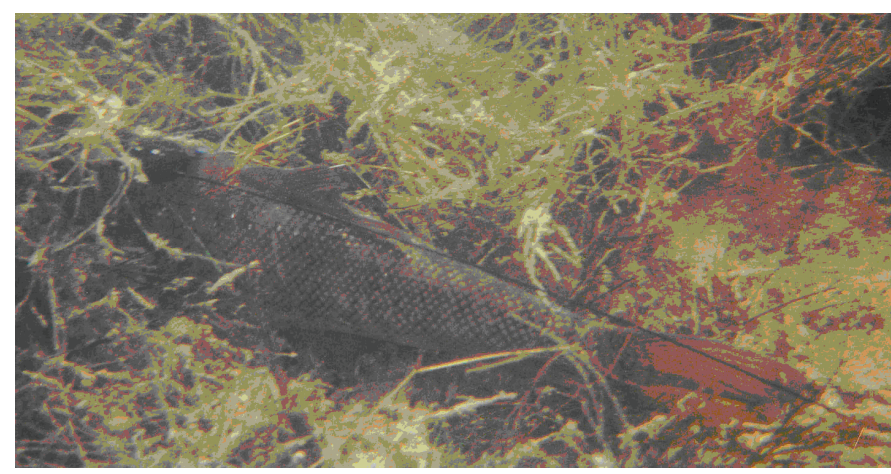

Fig. 41. A juvenile razorback sucker hiding its head in aquatic vegetation. The fish was part of a telemetry study. Note the antenna extending from the transmitter backpack. Photo courtesy of Paul Aguirre, Bureau of Reclamation.

1990; Modde and Irving, 1998; Mueller and others, 2000). The maximum distance observed was $17 \mathrm{~km} /$ day, with fish easily traveling $>100 \mathrm{~km}$ in a year. Distances traveled were similar for fish found in either reservoir or river habitats. Suckers moved 30-60 km in rivers (one-way) (Tyus and Karp, 1990; Modde and Irving, 1998) and 40-50 km in reservoirs during their spawning migration (Mueller and others, 2000; Karp and Mueller, 2002).

Valdez and Masslich (1989) reported that during the winter, razorback suckers remained within a $1.6-4.8 \mathrm{~km}$ reach of the river. Daily movements were typically restricted to $25-$ $31 \mathrm{~m} /$ hour as fish moved between microhabitats, where they often remained for hours. Reservoir fish typically remained close to shore in water $<50 \mathrm{~m}$ deep, and the degree of movement or distance traveled varied greatly among individual (Tyus and Karp, 1990; Holden and others, 1997; Mueller and others, 2000).

Razorback suckers historically migrated to specific spawning areas where they would congregate in the hundreds, possibly thousands (Jordan, 1891; Hubbs and Miller, 1953). Recent studies suggest suckers, especially males, exhibit fidelity to specific spawn sites (Tyus and Karp, 1990) but may also have spawned at more than one site (Modde and Irving, 1998; Mueller and others, 2000). Popular spawning grounds included the alluvial debris fans found at the confluences of tributaries, major washes, and more recently, wave-washed shorelines in reservoirs where gravel and cobble substrates have been flushed of sediments (Minckley, 1973; Tyus and Karp, 1990; Minckley and others, 1991). The single commonality appears to be appropriate substrate, a mixture of large gravels and small cobble (Minckley and others, 1991).

The range of physical conditions used by razorback suckers to spawn is wide. They spawn in both standing and flowing waters at depths ranging from shallow $(0.25 \mathrm{~m})$ to deep (25 m) (Holden and others, 1997). Spawners prefer gravel or cobble substrates. Descriptions of spawning behavior are more common in reservoirs due to water clarity and the abundance of reservoir populations.

\section{Reproduction}

Modde and Irving (1998) reported that spawning migrations in the Upper Basin were triggered by spring runoff. However, spawning occurs in the Lower Basin several months prior to runoff, suggesting water temperature may be a key triggering factor. Generally, spawning peaks when water temperatures reach $14-16^{\circ} \mathrm{C}$ (Minckley, 1983; Snyder and others, 2004). Successful egg incubation can occur at $10^{\circ} \mathrm{C}$ but Marsh (1985) reports that optimal survival occurs closer to $20^{\circ} \mathrm{C}$. The ability to spawn over a $15^{\circ} \mathrm{C}$ temperature range is noteworthy for any species and again illustrates the species adaptability to highly variable environmental conditions.

Females become mature after their third or fourth year and at sexual maturity can produce between 75,000 to 200,000 eggs annually (McAda and Wydoski, 1980; Minckley, 1983). Males can become sexually active during their first year of life. It is believed females intermittently spawn over a prolonged ( $>6$ weeks) period. Spawning females were statistically more active compared to males, visiting multiple spawning sites and potentially spawning with dozens of males (Mueller and others, 2000). Spawners exhibit no parental care.

Unfertilized eggs are cream-colored (fig. 42) and when fertilized become nearly transparent, except for the yolk sack. Water-hardened eggs are $2.5-2.8 \mathrm{~mm}$ in diameter, negatively buoyant, and adhesive. Sexual tremors during the mating process have two useful purposes: first, the rapid finning flushes the substrates of fines that might suffocate eggs; second, it drives the adhesive eggs deep into the substrate making them more difficult for predators to find. The actual spawning act is quite abrasive to the fish's genital region; by the end of the spawning season, this portion of the fish's body is generally discolored and covered with bacterial and fungal infections. The anal fin of older females are often heavily calloused (Paul Marsh, ASU, oral commun., 2005).

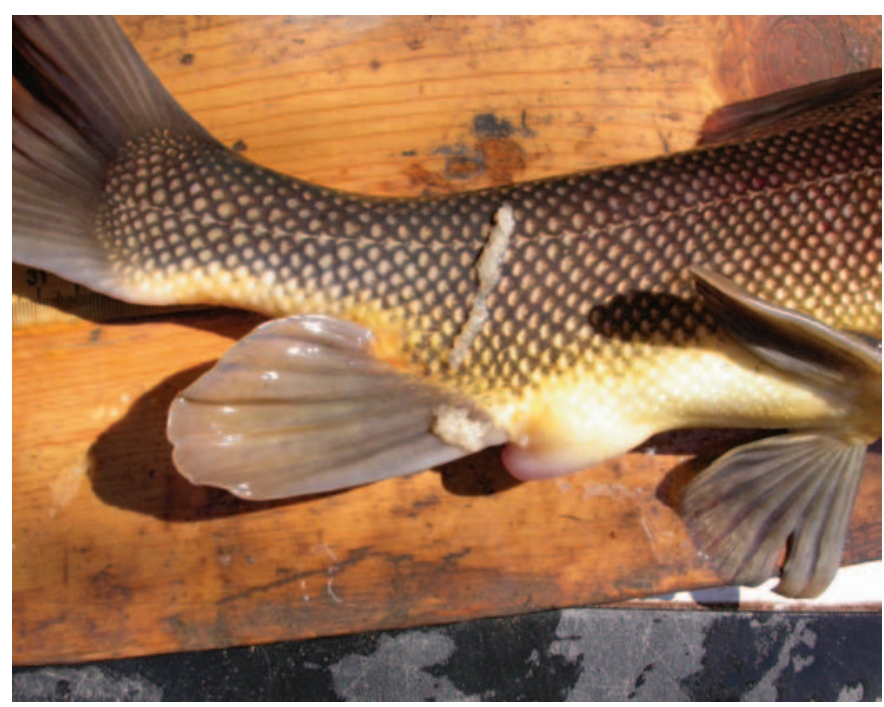

Fig. 42. Swelled genital region of a young razorback sucker female showing expelled eggs. 
This species also has a long spawning season. It starts in late December in the Lower River and progresses upstream as the river warms. Spawning can continue at a given location for nearly 10 weeks and can continue as late as June, depending on the water temperature during spring runoff (Tyus, 1987). This provides the species a 6-month reproductive season where flow conditions range from winter lows to high spring runoff (fig. 43).

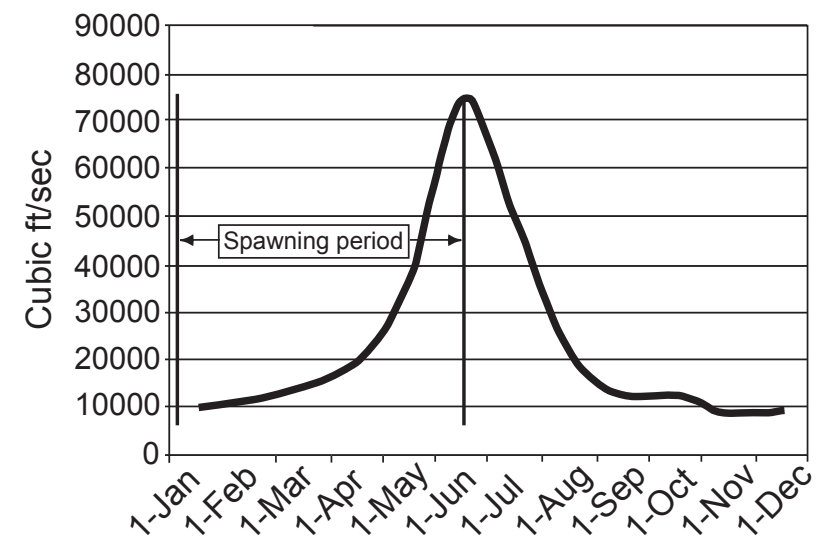

Fig. 43. Hydrograph for the Colorado River at Yuma, Arizona. Data represent monthly averages based on information collected from 1904 to 1934. The razorback sucker spawning season can extend from late December to late June.

\section{River Spawning}

Razorback suckers engaged in river spawning have not been observed in the Upper Basin due to the increased turbidity associated with spring runoff (Tyus, 1987). However, collections of "running" ripe male and female razorback sucker over a gravel-cobble bar at a depth of 1 to $3 \mathrm{~m}$ located in the Green River (Tyus, 1987) (fig. 44) were used to define a major spawning area; gravid females and ripe males have been collected from this location for nearly two decades (Tyus and Karp, 1990; Modde and Irving, 1998). Dale Ryden (USFWS, oral commun., 2005) reported collecting ripe fish in depths as shallow as $0.5 \mathrm{~m}$ in the San Juan River, where it appeared spawners were specifically selecting large gravels and cobble for spawning.

Mueller (1989) observed spawning downstream of Hoover Dam where water visibility exceeded $25 \mathrm{~m}$. Spawning occurred over an alluvial deposit of large gravels and cobble that had been deposited at the mouth of a dry wash. Water depth ranged from 1-2 $\mathrm{m}$ and water velocity from $10-40 \mathrm{~cm} / \mathrm{s}$ (figs. 45 and 46). These physical conditions were also present at two other river spawning areas that were recently discovered near Needles, California, where groups of 50 to 100 fish were observed over disturbed (cleaned) substrate, mid-channel at several locations (fig. 47). Spawning apparently occurred at each site over a relatively large area $\left(10 \times 50 \mathrm{~m}^{2}\right)$. Spawning events created depressions measuring $0.5-2.0 \mathrm{~m}$ in diameter

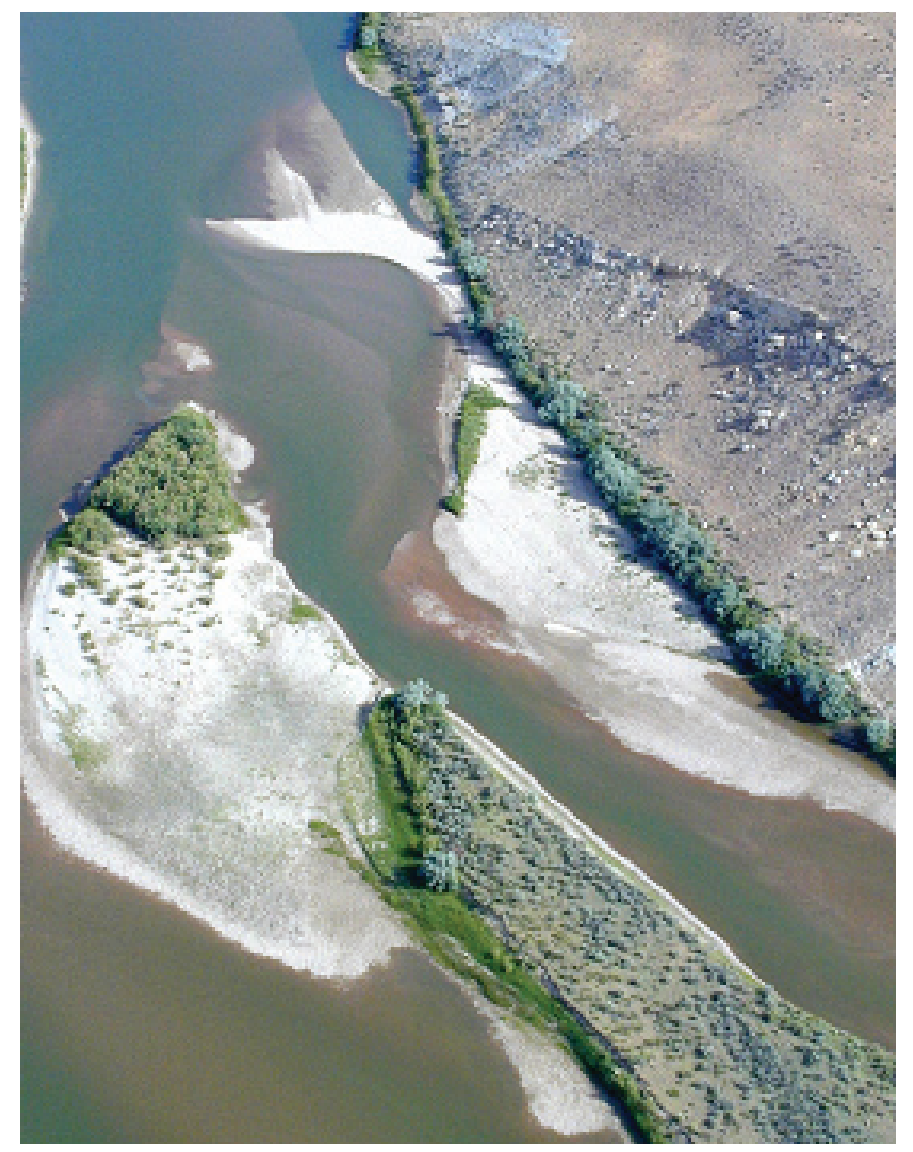

Fig. 44. The last known location (exposed gravel bar between the two islands) where wild razorback sucker spawn in the Green River near Jensen, Utah. Photo courtesy of Tim Modde, U.S. Fish and Wildlife Service.

and up to $10 \mathrm{~cm}$ deep. Substrate was composed of a mixture of clean gravels and cobble (fig. 48).

The spawning act was similar to spawning observed in reservoirs and resulted in obvious depressions in the substrate where spawning had occurred. Smaller adults, presumed to be males, rested along the bottom on the downstream portion of the Ringbolt Rapids spawning area. Occasionally, a large female would approach a spawning site from deeper waters, where she would be joined by two to five males. The fish would proceed a few meters upstream to spawn. Males at the Needles sites remained scattered throughout the spawning area. Some were observed lying in the spawning depressions; possibly these depressions provided some shelter from the current.

Behavior and body positioning were similar to that described in reservoirs, with the exception that fish were orientated into the current. Fish would gradually work their way over the spawning area, drop to the substrate, and discharge gametes. The event would take $2-5$ seconds. Having finished, females would leave the area; males would resume their positions on the spawning bar awaiting the arrival of another ripe female. Females were observed dispersed in deeper pools during the day, but were found resting along the shallow $(<25$ 


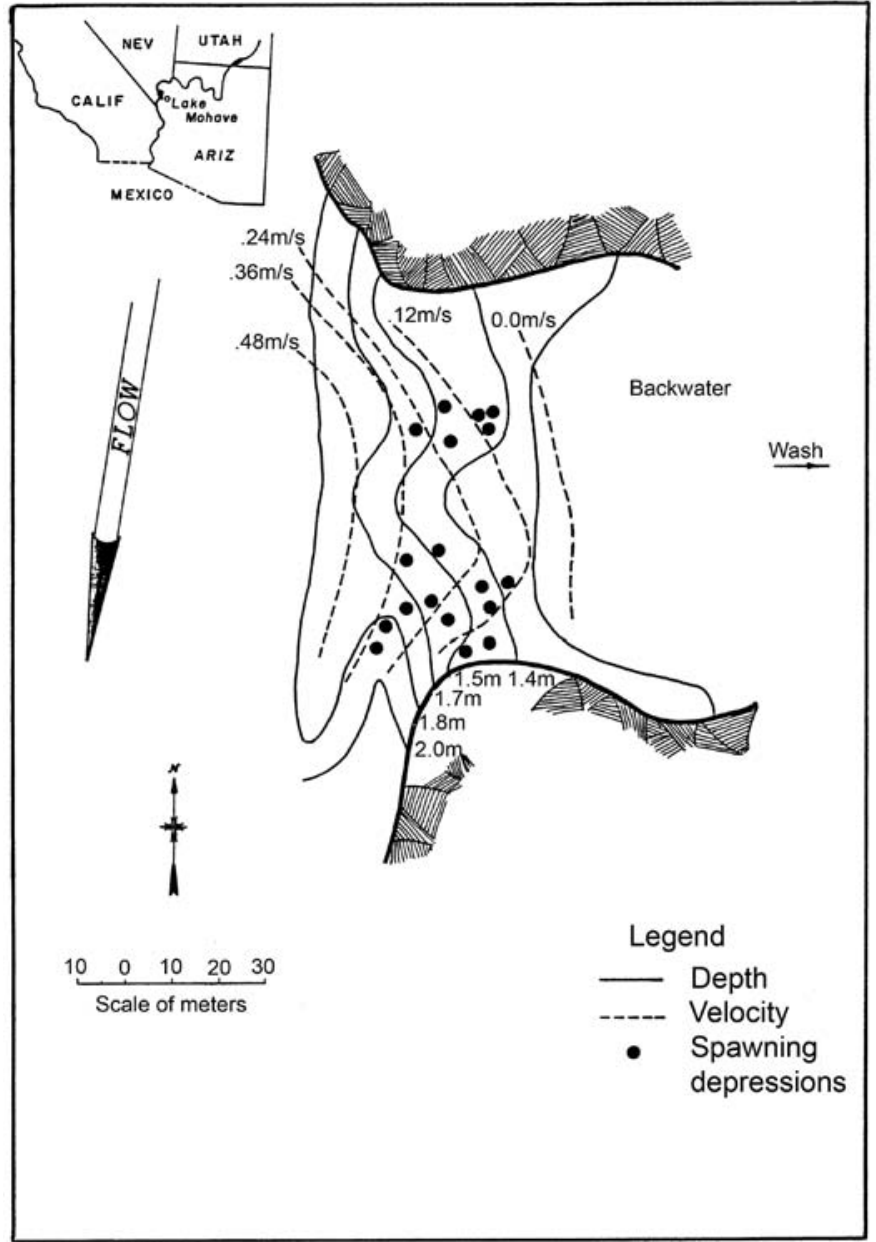

Fig. 45. A diagram of the Ringbolt Rapids spawning site located downstream of Hoover Dam showing water velocity, depth, and locations where spawning was suspected and observed.

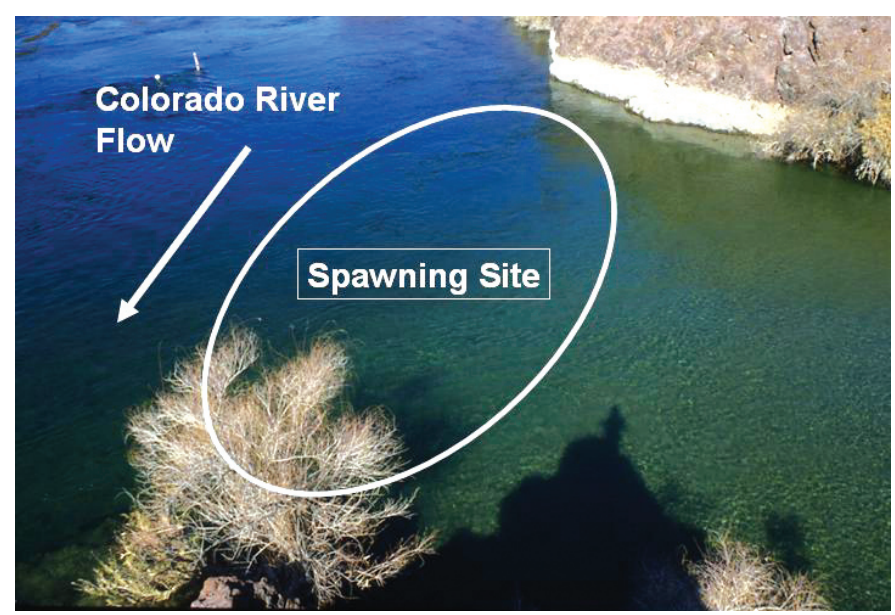

Fig. 46. A photograph showing where razorback suckers spawned at the Ringbolt Rapids site downstream of Hoover Dam.

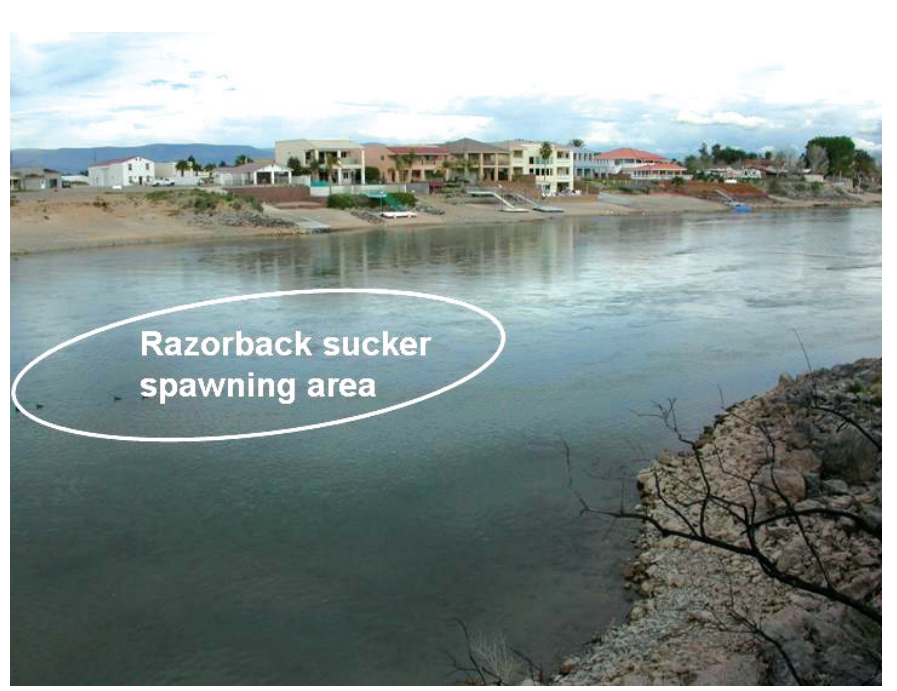

Fig. 47. Repatriated razorback suckers migrate possibly $40 \mathrm{~km}$ or more upstream from Lake Havasu to spawn near Needles, California. This is reputed to be a historical spawning location.

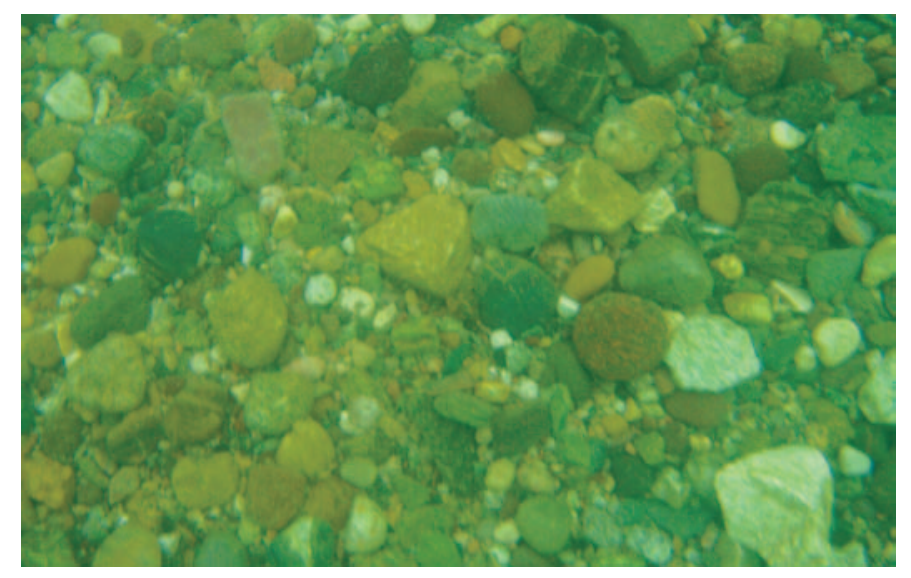

Fig. 48. Substrate used by spawning razorback sucker found in the mainstem Colorado River just upstream of Needles, California. The largest particle size shown was approximately $7 \mathrm{~cm}$ in diameter. Photo taken 5 March 2005.

cm depth) shoreline at night. Both eggs and larvae were found where spawning was observed (Mueller, 1989).

The Ringbolt Rapids site (fig. 46) had a few relatively large $(50 \mathrm{~cm})$ rocks scattered through the spawning site. I witnessed a unique behavior on several occasions. A spawning group (a female and multiple males) would align itself next to the downstream side of a large $(>50 \mathrm{~cm})$ rock that was located in fairly swift $(>40 \mathrm{~cm} / \mathrm{s})$ water. The group crowded behind the shelter of the rock and then began to tumble in a tight ball for 3 to 5 seconds while maintaining their position behind the rock. There was no evidence spawning took place, but this behavior may be some type of socialization. 


\section{Reservoir/Pond Spawning}

Following the filling of several large mainstem reservoirs in the Lower Basin, most notably Lakes Mead, Mohave, and Havasu, razorback suckers would congregate along the shoreline by the thousands to spawn in late winter and early spring (Minckley 1983) (fig. 49). Douglas (1952) was the first to describe the spawning behavior from a large spawning aggregate he observed in Lake Havasu. Single females were attended by 2 to 12 males. Males appeared to herd the female by nudging their heads and predorsal keels against her genital region (fig. 50). Fish randomly spiraled over the spawning area until the female, bracketed by the males, would settle to the bottom. Upon touching the bottom, they would rapidly vibrate their posterior regions when gametes were released. The fish would then gradually disperse. The spawning act took 1-5 seconds and often resulted in a cloud of silt and a depres-

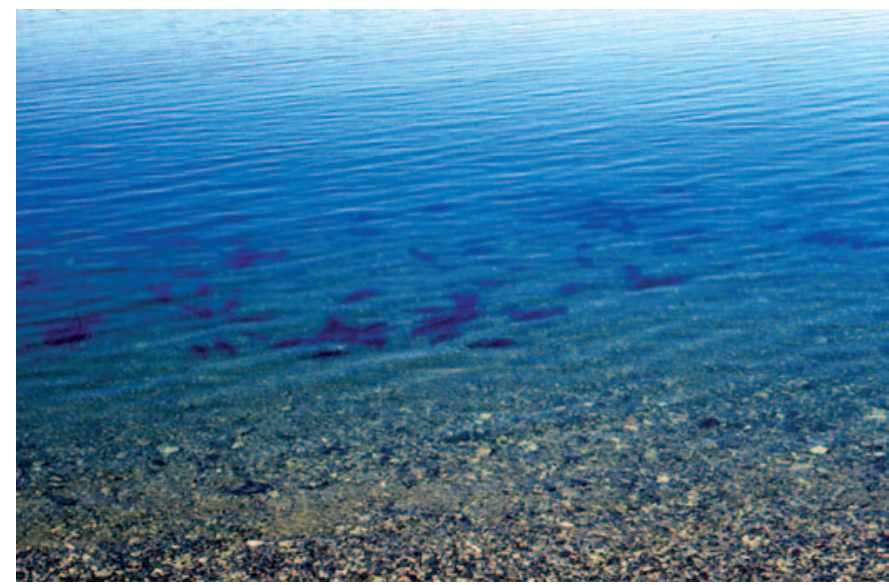

Fig. 49. Thousands of razorback suckers once spawned along the shoreline of the major mainstem reservoirs in the Lower Colorado River. This photograph shows a spawning aggregate in Lake Mohave, Arizona-Nevada.

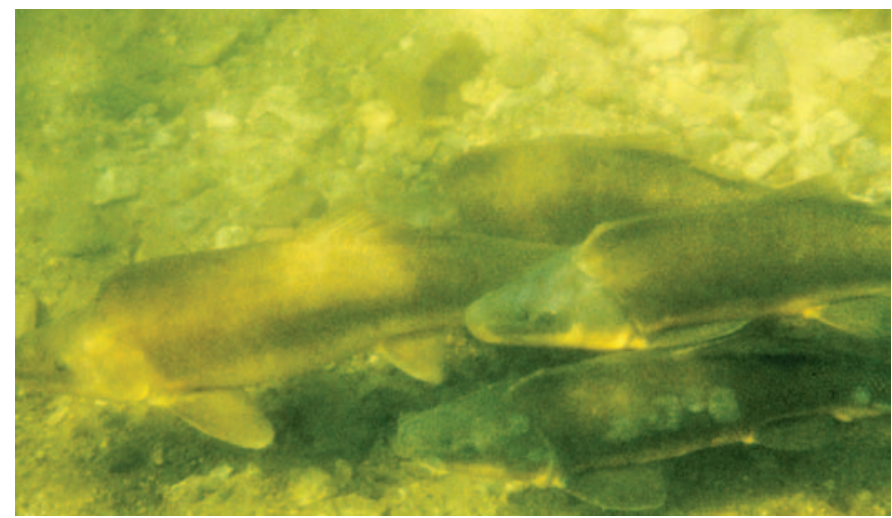

Fig. 50. A group of spawning razorback suckers. A female (left) is being bracketed by three courting males (right) in Lake Mohave, Arizona-Nevada. sion in the substrate. Spawning normally occurred at 1-4 m depths (Minckley and others, 1991), however, Holden and others (1997) reported spawning occurred as deep as $25 \mathrm{~m}$ in Lake Mead.

\section{Recruitment}

The recruitment strategy of the razorback sucker continues to remain a mystery. The species possesses one of the most adaptive reproductive capabilities for any large fish in the world. Despite a large reproductive potential, few historical reports suggest that young were commonly abundant. It is quite possible they were common and simply not noticed or reported. Miller (1961) reported seining 6,000 in Eldorado Canyon in 1951. This represents the earliest and only account I could find regarding the abundance of young razorback suckers. More recent reports suggest low numbers of young, which may or may not reflect human alterations.

For instance, Marsh reported a relatively low number (hundreds) of young surviving in Yuma Cove in 1986, while in 1993 only 296 survived (Pacey and Marsh, 1998). Modde (1996) reported a few $(<100)$ taken from Old Charley Wash over a two-year period. Ryden (2003b) reported a single juvenile taken from the San Juan River, and Golden and Holden (2003) reported capturing two suckers from Lake Mead that were less than 10 years old.

Spawning was first observed at CHLP in 1996, although there was no immediate evidence of young being produced (LaBarbara, 1999). Young-of-year suckers (<20 cm) were discovered in 1998 and 1999 during routine fall electrofishing (LaBarbara, 1999; Marsh, 2000). Young-of-year constituted $20 \%$ of the 1999 sample (Marsh, 2000) but were not detected during the 2000, 2001, 2002, and 2003 fall surveys. Sampling in the spring of 2004 revealed that limited recruitment had occurred in 2002 and 2003, but young constituted a small portion $(<5 \%)$ of the entire fish sample.

For years, the absence of young was attributed to sampling bias or not sampling in the right places, which can be a viable concern. The remarkable longevity of these relic populations lent credence to that belief. However, it is difficult to believe that after decades of studies, these fish have somehow evaded detection. Small bonytail $(<15 \mathrm{~cm})$ have been captured effectively in CHLP, but a fraction $(<1 \%)$ of the small fish captured were suckers. The continued absence or scarcity of intermediate-sized suckers suggests young life stages can indeed be rare even when recruitment occurs.

Poor survival of young and low annual recruitment may be typical for some long-lived catostomids. Flannelmouth sucker, another large native sucker, is found at the confluence of the Paria and Colorado Rivers and in the Colorado River downstream of Davis Dam. Annual recruitment of these populations is relatively low due to the virtual absence of young. Mueller and Wydoski (2004) found the majority of spawners 
downstream of Davis Dam to be 8 to 13 years of age, and annual recruitment of sexually maturing adults was $<15 \%$ a year. While this rate appears low, it is sufficient to maintain a viable population of long-lived species (McKinney and others, 1999; Mueller and Wydoski, 2004).

Cibola High Levee Pond contained approximately 1,000 mature razorback suckers. Based on their longevity and population size, an average recruitment of 50 individuals could maintain the population if the average age was 20 years. If it were only 10 years, similar to what was found with flannelmouth sucker (Mueller and Wydoski, 2004) 100 young adults a year could maintain that population.

The absence of large numbers of young, even under optimal conditions, is puzzling. It appears initial (first few weeks) survival rates are quite poor but then increase dramatically. I wonder if this condition is predisposed. Quite possibly the recruitment strategy of the razorback sucker evolved in producing embryos, which individually had relatively narrow tolerance levels but collectively ensured limited survival over a broad range of environmental conditions. In other words, evolution guaranteed some survival regardless of environmental conditions. This is sheer speculation on my part, but possibly the recruitment strategy was as unique as the fish itself.

Historically, the extended spawning season (December to mid-June) provided a wide range of opportunities and threats. The extended growing season allowed fish to easily obtain lengths $>30 \mathrm{~cm}$ (Mueller, 1995) which reduced predation risks. However, food was scarce in late winter and spring, and larvae became one of the first available food items in spring for predators. In addition, reduced flows and clearer conditions afforded them fewer places to hide from predators.

Fish hatched during the late spring runoff had the benefit of turbid conditions and vast expanses of recently flooded nursery habitat. Turbid flood waters helped disperse newly hatched larvae, along with flood debris that helped conceal young fish. Unfortunately, much of this newly created habitat was temporary, lasting only a few days or weeks until floods receded. Often fish were stranded or forced back into the channel by retreating waters. Small fish were at a disadvantage, being smaller and less mobile than suckers hatched months earlier.

The annual range of flow conditions, temperatures, and ages of young entering the most productive nursery areas provided an unusually complex variety of environmental conditions that ensured some level of survival in at least some years. The ecological volatility of the Colorado River may have made this recruitment strategy necessary.

\section{General Behavior}

\section{Larvae}

Newly hatched larvae are approximately $7-10 \mathrm{~mm}$ in length when they emerge from spawning gravels. They have little mobility for 6 to 10 days as their fins develop. They swim up into the water column after their second week to start feeding, dependent upon temperatures (Snyder and others, 2004). Larvae are phototactic during this period and are easily attracted and captured with light traps (Mueller and others, 1993) (fig. 51). The attraction to light may help orient larvae toward zooplankton which are normally more plentiful in the upper portions of the water column.

Larvae soon disperse along the shoreline and are frequently found in backwaters or protected areas hiding in submerged vegetation, woody cover, or debris (Muth and Wick, 1997; Mueller, 2003). Their movements are aided by flow or wind-generated drift. Langhorst and Marsh (1986) reported they were seldom found in open water. By the time they reach $25 \mathrm{~mm}$, they often begin schooling and are capable of forming large schools (Snyder and others, 2004).

There has been a great deal of speculation regarding their ability to recognize and avoid predators since they evolved in a predator-sparse community. So far studies have been inconclusive one way or the other. Smith (1992) suggested larvae had equal to greater predator avoidance than species that evolved in the Mississippi River drainage. Johnson (1997) reported the avoidance of green sunfish (Lepomis cyanellus) by young razorback suckers was extremely poor. He pointed out that larvae preferred clear water conditions that actually increased predation risk.

Larvae remain vulnerable to a host of predators that range from insect nymphs to small fish (Horn and others, 1994) (fig. 52). Horn and others (1994) illustrated that odonate nymphs easily captured and devoured razorback sucker larvae when placed together in aquarium tanks. Similar tank test experiments showed larval suckers were preyed upon by a host of juvenile nonnative fishes (Mueller and others, 2005). Some of the most aggressive species are commonly found in nursery areas, including the common carp (Cyprinus carpio), red shiner (Notropis lutrensis), green sunfish (Lepomis cyanelus),

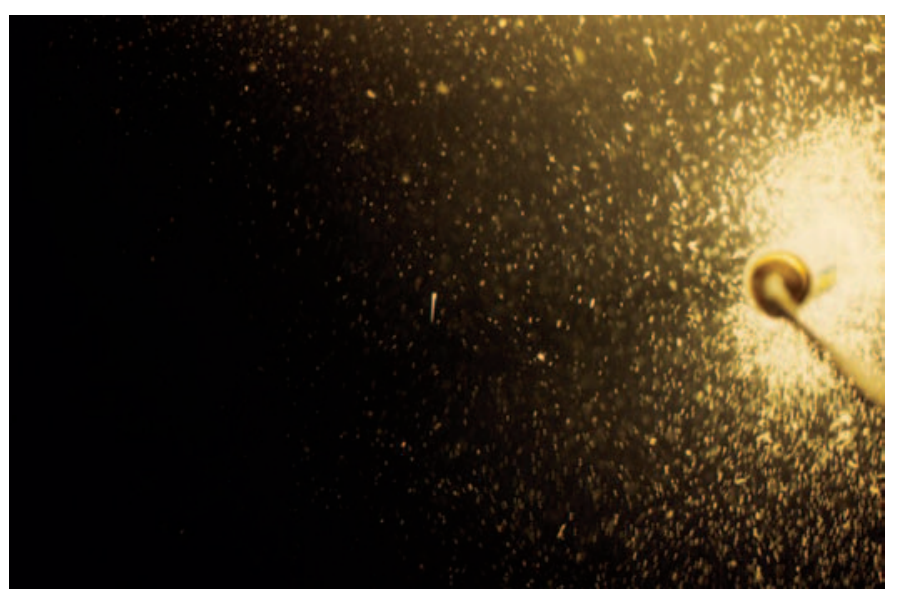

Fig. 51. Razorback sucker larvae are phototactic (i.e., attracted to lights). Lights are a common method of collecting larvae in Lake Mohave for propagation. A larva is located in the center of the photograph among a swarm of zooplankton. Larvae are fondly referred to as "two eyes and a wiggle." 


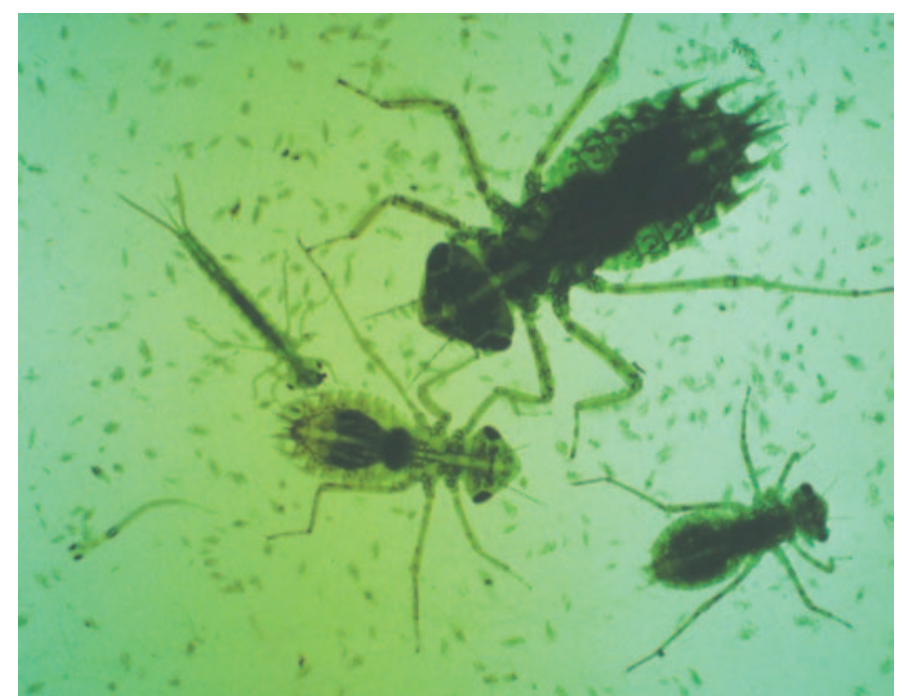

Fig. 52. Organisms (zooplankton, larval fish, insect nymphs) attracted and captured in a light trap. Biologists use a light table and clear glass tray to sort samples. Fish larvae are removed using an eye dropper. Notice the size difference between the razorback sucker larvae located in the lower left corner with dragonfly and damselfy nymphs which feed on fish larvae.

bullhead (Ictalurus spp.), and even bullfrog tadpoles (Rana catesbeiana) (Mueller and others, 2005).

\section{Fry and Juveniles}

Early life stages generally disappeared from the wild before scientists had an opportunity to study them. Available information is limited to hatchery-produced young, except at CHLP and rare occurrences in the wild. Fry (1.5-2.5 $\mathrm{cm}$ ) were commonly found dispersed along shore, among emergent vegetation (cattails) and in brush located along the deeper portions of the shoreline $(>50 \mathrm{~cm})$. Small schools of fry $(20-25 \mathrm{~mm})$ were also discovered in a backwater in upper Lake Havasu (Wydoski and Mueller, 2004). Fry larger than 25 $\mathrm{mm}$ are either absent, extremely scarce, or extremely reclusive in the wild.

Scuba and telemetry surveys revealed juveniles are secretive during daylight hours and are often concealed in cover (Mueller and Marsh, 1993, 1998). Divers examined juvenile activity in rearing ponds but only observed fish after dark. Juveniles emerged from dense stands of Potamogeton spp. after sunset when it is suspected that they feed (Mueller and Marsh, 1993).

Their preference for dark, confined areas leaves them vulnerable to water development hazards (e.g., diversion, dam passage, hydropower loss). For example, several hundred juvenile suckers successfully navigated $150 \mathrm{~m}$ of underground piping ( $30 \mathrm{~cm}$ diameter) to move between two golf course ponds (Mueller and Wick, 1998). Likewise, monitoring on Lake Havasu discovered 13 marked razorback suckers that had successfully passed from Lake Mohave through the hydropower turbines at Davis Dam (Richard Wydoski, BOR, oral commun., 2005). This leaves us to question how many others were killed during their attempted passage (Mueller, 2003). Marsh and Kesner (2000) reported similar movement through Headgate Rock Dam.

\section{Adults}

Anyone handling an adult is immediately impressed by the strength and generally docile nature of the species. There have been reports of people actually capturing suckers bare handed and of coyotes snatching spawners from the shoreline (Mueller and Marsh, 2002; Mike Burrell, NDOW, oral commun., 2000). They are an extremely strong and hardy fish that seldom struggle when they are entangled in nets or handled. They can be approached with caution when snorkeling or diving and appear curious. Adults have been encountered individually, in small groups, and in large schools that can number $>100$. I observed fish with radio transmitters actually swim up to the boat during tracking studies.

Adults use cavities similar to juveniles. Two adults ( $>25$ year olds) were captured in the Central Arizona Project Canal System after the system had just become operational (Marsh and Minckley, 1989; Mueller, 1990). The fish had to have passed through the Lake Havasu Pumping Plant, which lifts water $250 \mathrm{~m}$ to the Hayden-Rhodes Aqueduct.

Adults exhibit a remarkable ability to survive summer heat $\left(>34^{\circ} \mathrm{C}\right)$. Reservoir fish typically descend in the water column to cooler $\left(18-22^{\circ} \mathrm{C}\right)$ depths during the summer (Mueller and Marsh, 1998). In shallow ponds that have depressed oxygen concentrations $(<1 \mathrm{mg} / \mathrm{L})$ adults basically "shut down," suspending themselves on or near the bottom where temperatures are cooler. The fish appeared to be in a trance, avoiding all activity. Similar periods of inactivity were also reported for the winter by Valdez and Masslich (1989). Inactivity conserves energy resources and lowers oxygen requirements.

\section{Eye "Blinking"}

Underwater videography documented a unique behavior. Suspected spawning males would often lie quietly on the bottom. On occasion these fish would exhibit a distinctive eye "blinking" behavior. On closer examination, I found the species has the ability to roll and expose the shiny lining (sclera) of its eyes, causing a distinctive white reflection. This unique peculiarity proved to be relatively common $(n>50)$ in roughly 10 hours of film I reviewed.

Typically, prey species have monocular vision, their eyes working independently, but razorback blinking occurs in both eyes (figs. 53 and 54). Spawning occurs during the waning months (January through March) of winter, prior to spring runoff and turbid conditions. This, combined with the dark, camouflaged nature of the fish, makes it difficult to imagine that this ability does not have some purpose. Similar blinking 


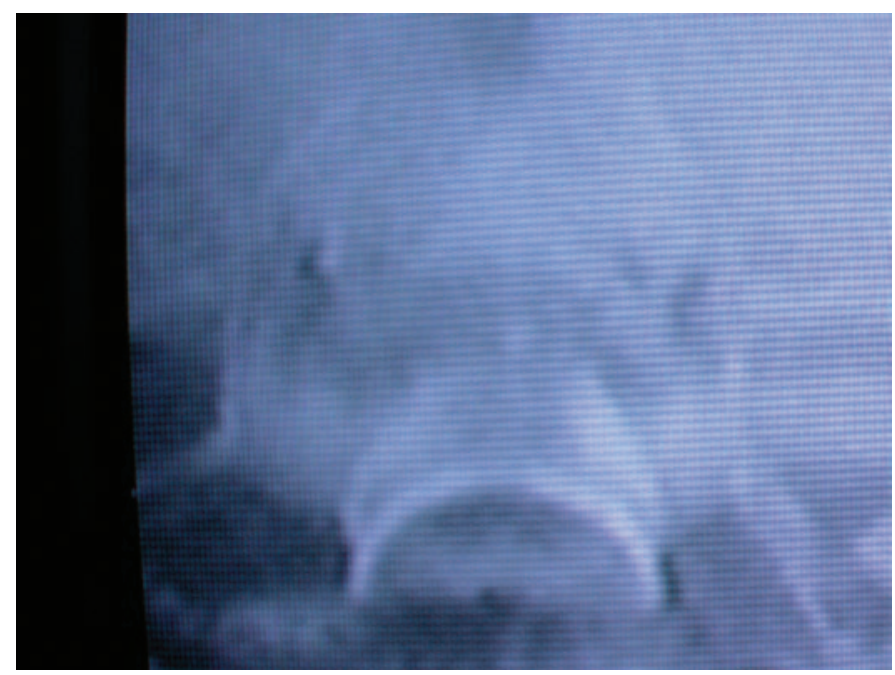

Fig. 53. Photograph showing a spawning razorback sucker resting on the bottom of Cibola High Levee Pond.

behavior has been observed in the courtship behavior of the turtle Trachemys s. scripta (Lovich and others, 1990). I believe it may be a spawning display to attract females and/or possibly a territorial or vicinity warning between males. Unfortunately, large adults disperse after spawning, making it impossible to test whether this is a specific spawning-related display.

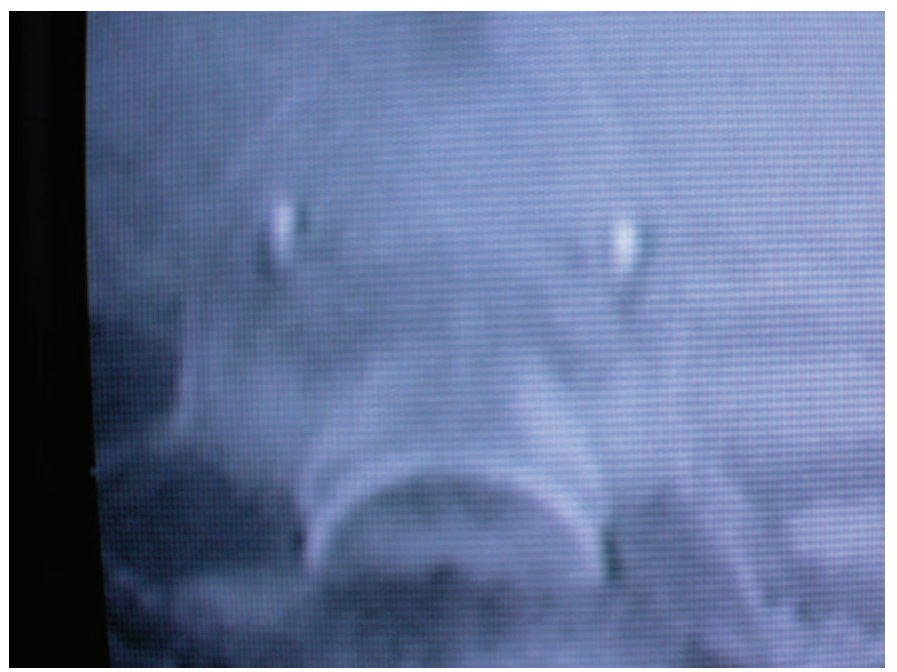

Fig. 54. A frame grab of the same fish exhibiting the "blinking" phenomenon, where fish roll their eyes to reveal the highly reflective interlining of the eyes. This behavior is believed to be a spawning or possibly a territorial display. 


\section{Chapter 2. Complete Life Cycle of Two Endangered Fishes at Cibola High Levee Pond}

The native fish community at Cibola High Levee Pond (CHLP) provided unprecedented access to not only large numbers of native fish but also their young, which have been absent or scarce in the wild for several decades. Few biologists have had the privilege to observe these species, let alone study their entire life cycle. Likewise, it was sobering to witness their rapid demise. In just one year, largemouth bass spawned and numerically replaced the native community. The five-year experience reaffirmed their unique ability to thrive in isolated habitats as well as their vulnerability to nonnative predators. It also provided evidence of the historical role of oxbow communities and their potential role in the recovery of these species.

The fish's success at CHLP happened by chance. C.O. Minckley (oral commun., 1993, USFWS) renovated CHLP for the purpose of using it as a grow-out facility for bonytail and razorback sucker. His strategy was to grow fish to a larger size to improve their survival when they were stocked into the river. Remarkably, the CHLP fish matured and produced young.

The importance of this event cannot be overemphasized. These species were generally believed to require river conditions to complete their life cycle; it is obvious they do not. I learned four important lessons. First, the species are remarkably adaptive to physical conditions, being able to spawn in both current and standing water. Second, it reaffirmed they produced young in the absence of nonnative predators. Third, survival occurred even with some level of nonnative predation (e.g., introduced bullfrogs [Rana catesbeiana] and crayfish [Procambarus clarkii]). Fourth, these isolated habitats provide a sanctuary for these fish to establish self-sustaining communities (see Chapter 3).

\section{Introduction}

\section{History and Study Area}

Cibola High Levee Pond is located adjacent to the Lower Colorado River approximately $50 \mathrm{~km}$ downstream of Blythe, California (fig. 55). The pond is in Cibola National Wildlife Refuge and was originally a section of the river's main channel. It was isolated when the river was straightened by dredge in the 1960's. The state boundary of Arizona and California runs through the pond, emphasizing its historical location. The river and high levees isolate this historical section of the current and historical river channel.

The pond is diamond-shaped with a surface area of slightly more than 2.3 ha (fig. 56). It is relatively shallow, with depths seldom exceeding $1.5 \mathrm{~m}$ except for a small depression (3.5 m) located adjacent to the river levee (fig. 57). The pond is hydraulically connected to the river and fluctuates with river stage. Since water development, the Lower River is solely regulated to deliver irrigation water to Imperial, Coachella, Yuma, and Mexicali valleys. River stage is highest during late spring and summer to meet irrigation demand, and flows decline with agricultural need by late fall. The pond's water elevation fluctuated approximately $1 \mathrm{~m}$ during the irrigation cycle and $1.5 \mathrm{~m}$ during this study.

Two of its four shorelines were maintained with riprap; the remaining two were historically armored but have long since grown over with brush (e.g., mesquite, salt bush [Atriplex spp.], and salt cedar [Tamarisk spp.]). Cattails (Typha spp.) dominate the northwestern shoreline, while brushy terrestrial vegetation (mesquite, salt cedar) inhabits the southeastern shore. Dense stands of submergent vegetation, including spiny naiad (Najas marina) and pond weed (Potamogeton spp.), are scattered throughout the pond (fig. 58). Vegetative growth during the summer mats the surface and fills much of the water column (fig. 59). Aquatic vegetation dies back during the winter months. Substrates vary from large rock, cobble, gravel, sand, and accumulated fine sediments (fig. 58).

A massive stocking program introduced more than 12 million small razorback suckers into Arizona waters in the 1980's (Johnson, 1985) but failed to reestablish the species, primarily due to nonnative predation (Marsh and Brooks, 1989; Minckley and others, 1991). Stocking strategies shifted toward raising larger fish to reduce predation losses (Mueller, 1995). When the USFWS established CHLP as a grow-out facility in 1993, the pond was chemically renovated using rotenone, then stocked with 58,000 small $(10-15 \mathrm{~cm})$ bonytail and 14,000 razorback suckers. Fish growth was monitored and during the fall, fish $>30 \mathrm{~cm}$ were removed and stocked elsewhere. Small numbers of nonnatives continued to show up during sampling: LaBarbara (1999) removed small numbers of threadfin shad and bluegill, and Marsh (2000) reported the presence of threadfin shad and mosquitofish.

Young bonytail and razorback suckers were discovered during the sampling effort in 1998 and fully documented in 1999 (Marsh, 2000). Both species were known to be able to produce young when isolated from nonnative predators (Pacey and Marsh, 1998), but this represented the first documentation of both species reproducing together for nearly five decades (Douglas, 1952; Jonez and Sumner, 1954).

\section{Ecological Importance of Cibola High Levee Pond}

Physically, the pond represents a historic oxbow frozen in time. Annual spring floods that averaged $>2,200 \mathrm{~m}^{3} / \mathrm{s}$ no longer inundate and reshape the flood plain; they are captured upstream, behind Glen Canyon and Hoover Dams. These floods were a dynamic force that scoured sediment, cut new channels, and deposited sediment and woody debris along the flood plain. The river had a broad and active flood plain as annual and seasonal floods constantly reshaped the river (fig. 60). Those hydraulic forces were harnessed 70 years ago, 


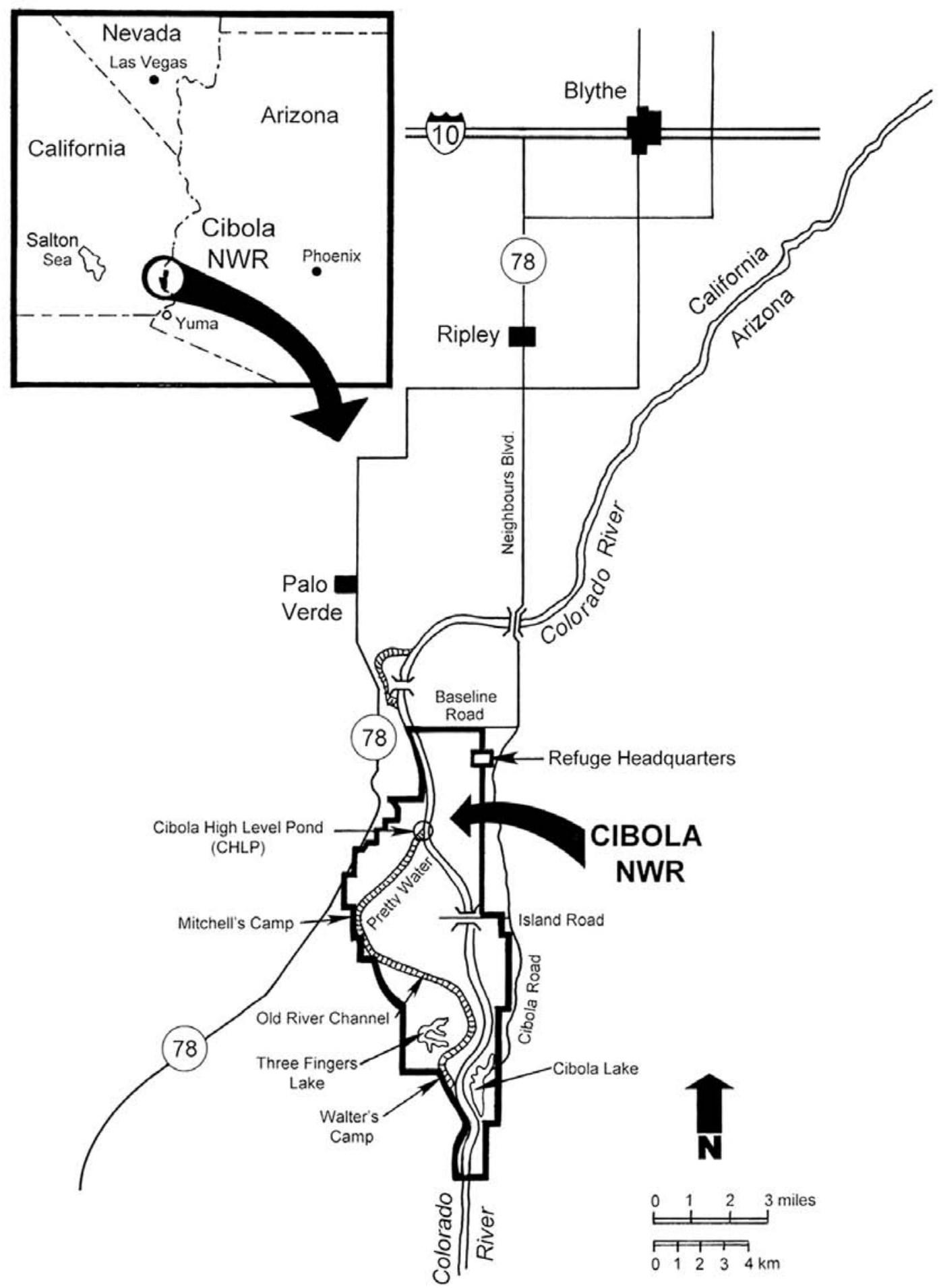

Fig. 55. General map of the locaton of Cibola National Wildlife Refuge and Cibola High Levee Pond, Arizona-California. 


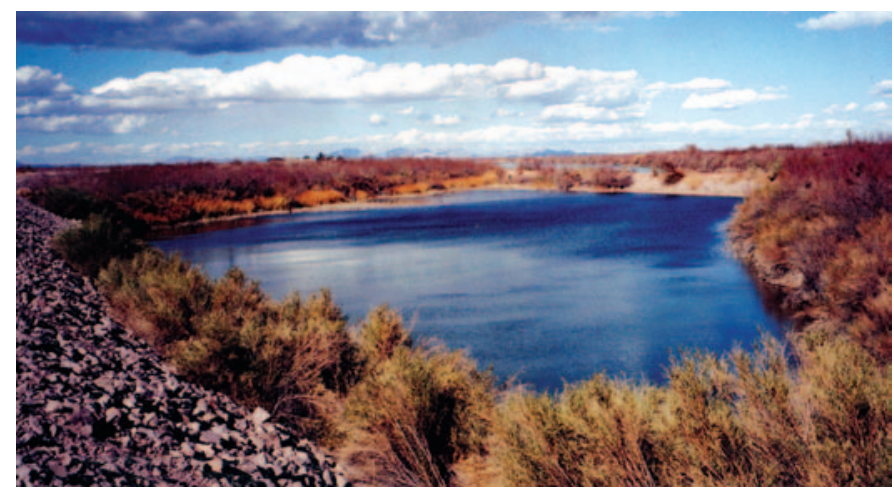

Fig. 56. Cibola High Levee Pond taken from the high levee looking north to the river levee. The Colorado River can be seen just beyond the river levee in the upper right corner of the photograph. The west (right) side of the pond is Arizona, and the east (left) is in California.

beginning with the construction and closure of Hoover Dam. Introduced fishes reaped the benefits of stabilized conditions and have since spread in number and distribution to literally dominate all portions of the river basin.

The role of oxbow communities is difficult to appreciate with today's landscape. Historically, summer flows would drain the flood plain, and only the deepest scoured depressions or canyon reaches maintained flow. Droughts would aggravate seasonally low conditions. River flows could become subterranean; or, what surface water remained was spread thinly over the broad alluvial flood plain, making it uninhabitable for fish of any size. Fish were subject to stranding, desiccation, and avian predation, which naturally suppressed population numbers. This "reset" process helped control predator distribution and pressure on young fish (Christopherson and others, 2004). Only fish that found permanent, deep habitats located in canyon gorges and deeper oxbow habitats were spared.

Evidence to date suggests the river typically supported very few fish (Grinnell, 1914). Evolution of only one main predator, the Colorado pikeminnow, suggests that prey were scarce or possibly absent at times. In addition, the remarkable fecundity, longevity ( $>40$ years), and ability of both species to spawn under varying conditions suggest survival and natural recruitment were generally low. Genetic research suggests that catastrophic droughts may have naturally devastated fish populations every few thousand years (Douglas, 2003) and possibly led to the extinction of others (La Rivers, 1962). It was a harsh environment! Isolated oxbow communities, similar to CHLP, served as sanctuaries for these species. Likewise, the last relic populations of bonytail and razorback sucker were typically found in reservoirs and gravel pits that more closely mimic the physical conditions found in oxbow habitats (Minckley, 1983)

\section{Water Quality Parameters}

\section{Temperature}

Water temperatures fluctuate seasonally, ranging from $10^{\circ} \mathrm{C}$ to $34^{\circ} \mathrm{C}$. Surface temperatures become quite warm, near- ing $34^{\circ} \mathrm{C}$ on calm sunny days, and fluctuate nearly $4^{\circ} \mathrm{C}$ during the daily cycle (fig. 61). These fluctuations, combined with cooler $\left(31^{\circ} \mathrm{C}\right)$ ground water, help disrupt thermal stratification that at other locations has caused anoxic conditions (Brouder and Jann, 2004).

\section{Dissolved Oxygen}

Dissolved oxygen levels remained remarkably high (>3 mg/L) during the summer months. More than $95 \%$ of the pond's volume maintained levels $>6 \mathrm{mg} / \mathrm{L}$, and there was no evidence of anoxic conditions. Oxygenation appeared to be influenced by the pond's hydraulic connection with the river and diel cooling at night. Low conductances in the pond's depression suggest river water and possibly ground water are entering the pond at this location and provide circulation that maintains adequate water quality.

\section{Conductance}

Cibola High Levee Pond's salinity fluctuates seasonally in response to river flow (elevation). Conductance generally peaks in winter, reflecting evaporation in late winter and suspected declines in water exchange from the river. Pond waters are typically freshened by an influx of less saline river water in late spring and early summer (fig. 62). It is speculated that higher spring flows may increase the hydraulic pressure and volume of ground water entering the pond from the river and exiting toward Pretty Water (fig. 55). This water exchange maintains lower pond salinity than what would be expected if the site were hydraulically isolated (Brouder and Jann, 2004).

\section{Aquatic Community}

\section{Zooplankton}

The zooplankton community was highly seasonal, with the majority of production occurring during early spring (fig. 63). Numerically, rotifers made up more than $90 \%$ of the invertebrate community, followed by copepods and then cladocerans. The most common rotifers were Hexarthra mira, Keratella cochlearis, and Polyarthra vulgaris. Daphnia ambigua and Eubosmina tubicen were the most common cladocerans.

Copepod species included Acanthocyclops vernalis, Cyclopaid copepadid, Diacyclops thomasi, and Tropocyclops prasimus. Nauplii or immature stages of copepods, ostracods, and eubranchipods were also common.

\section{Fishes}

Five species of fish were represented in the 2,295 fish collected during the course of this study. They included bonytail, razorback sucker, bluegill, largemouth bass, and channel catfish (table 5). Natives dominated the community numerically $(99.9 \%$ ) until the spring of 2004 , when largemouth bass 


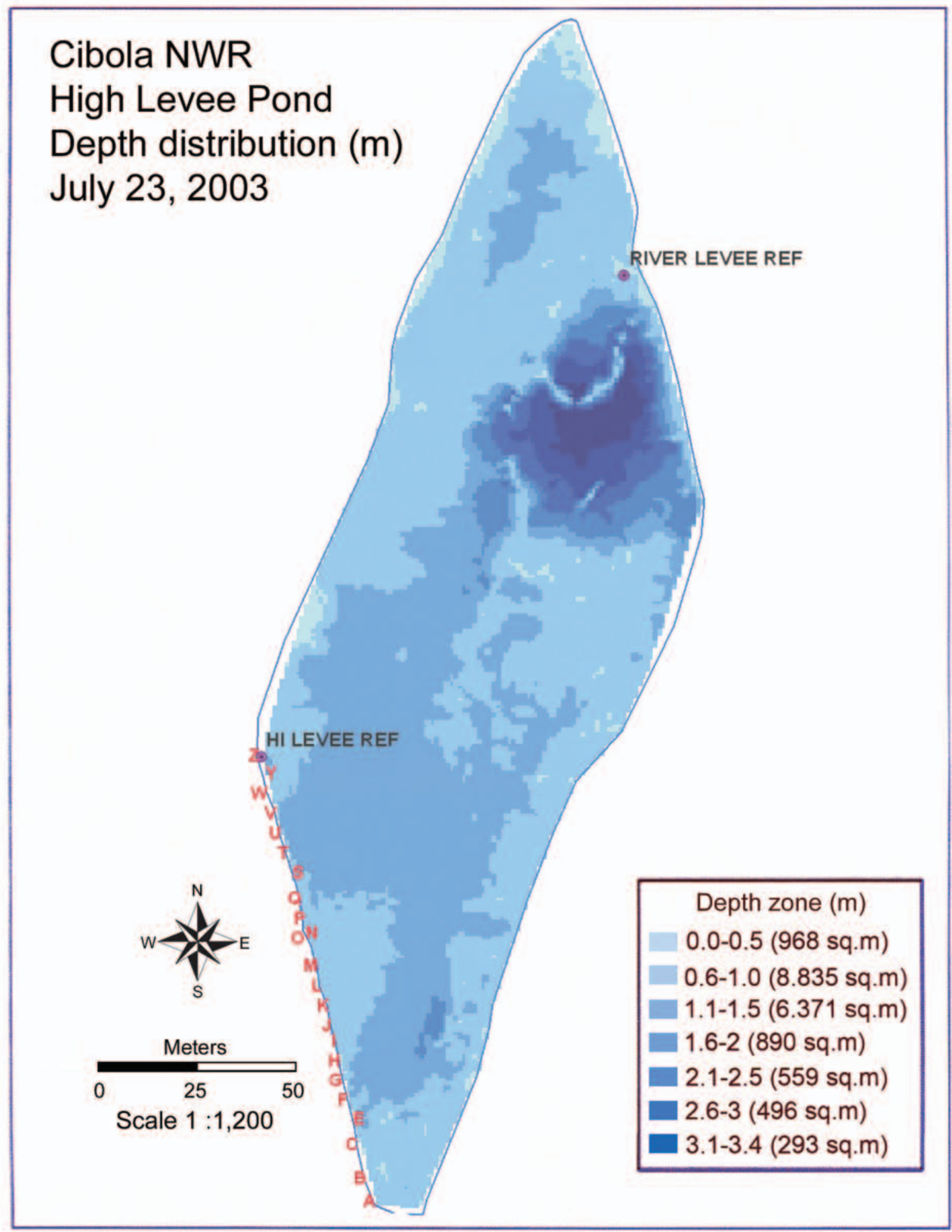

Fig. 57. Bathometry map of Cibola High Levee Pond taken during seasonally high flows on 23 July 2003. Red letters represent fixed reference points along the high levee used during telemetry studies. 


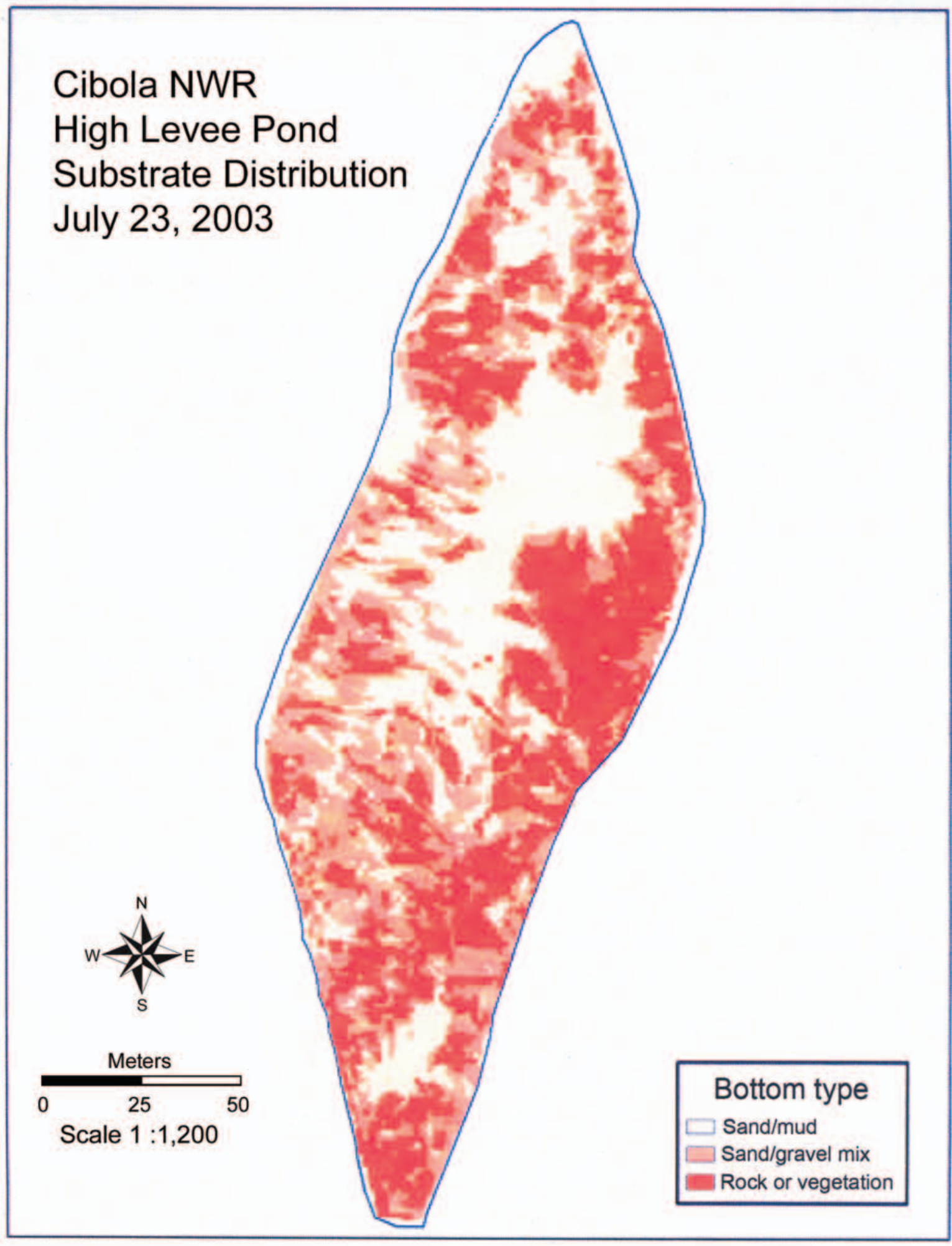

Fig. 58. Map showing the composition of bottom material at Cibola High Levee Pond based on acoustical profiling. Dark orange represents rock or vegetation. Rock was typically found adjacent to the armored levees, while submergent vegetation (Potamogeton spp. and Najas spp.) was found throughout the pond. 


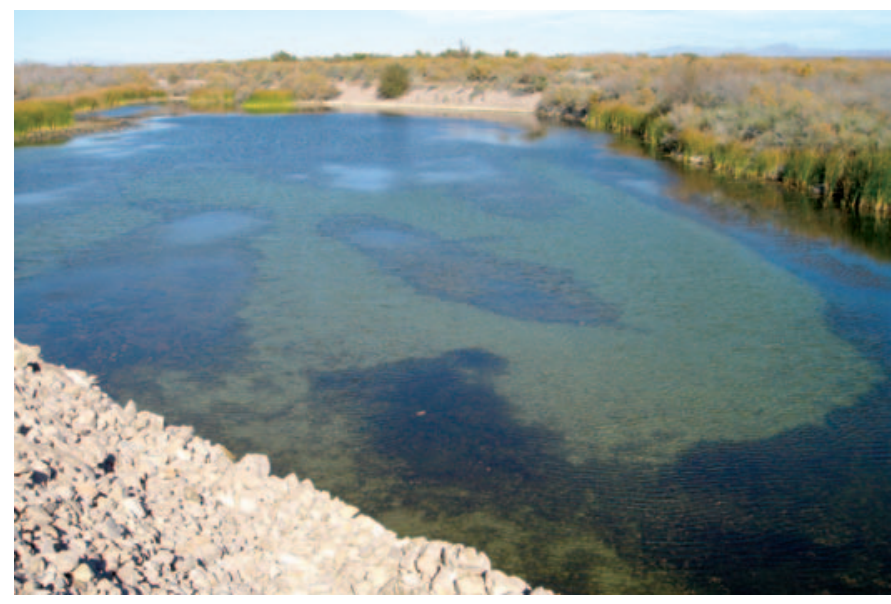

Fig. 59. Aquatic plant growth during the summer dominates much of the pond's volume and area. Dense stands of Potamogeton spp. and Najas spp. are found at all depths. Photograph is looking southwest toward the high levee and the northwestern shoreline that is dominated with cattail (Typha spp.)

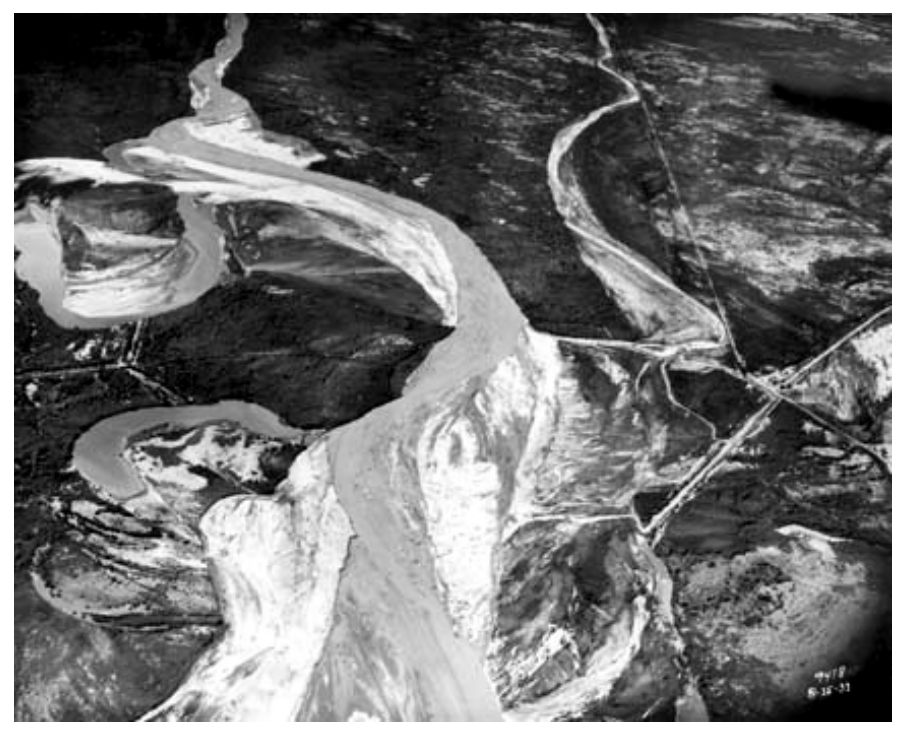

Fig. 60. Photograph (taken 15 August 1933) of the Colorado Delta region showing the complex network of side channels, oxbows, and wetlands that historically dominated the Colorado River flood plain. Photo courtesy of the Arizona Historical Society.

successfully spawned, producing thousands of young (fig. 64). The origin of the adults is unknown, but I suspect they were introduced by local anglers.

The native fish community consisted of small bonytail and large razorback sucker from the beginning of this study to 2004 (fig. 65). Literally tens of thousands of young bonytail were produced annually prior to the largemouth bass invasion. Our sampling techniques were only effective for fish $>15 \mathrm{~cm}$; nevertheless, population estimates (2002) suggested bonytail out-numbered razorback sucker 7 to $1(7,570+$ to 1,000$)$

Unlike bonytail, young razorback suckers were undetectable some years. The majority of the population consisted of

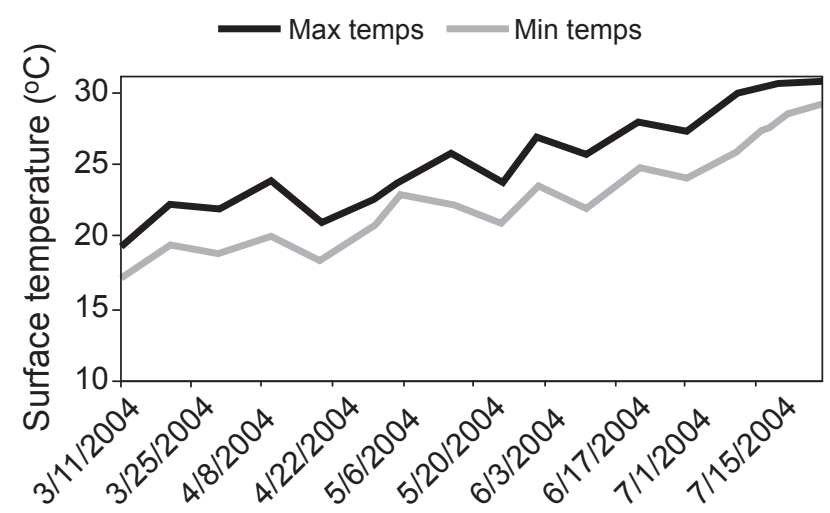

Fig. 61. Mean weekly diel temperature range of surface waters at Cibola High Levee Pond from 11 March to 28 July, 2004. Maximum temperature for the recorder was $31^{\circ} \mathrm{C}$; actual highs reached $34^{\circ} \mathrm{C}$.

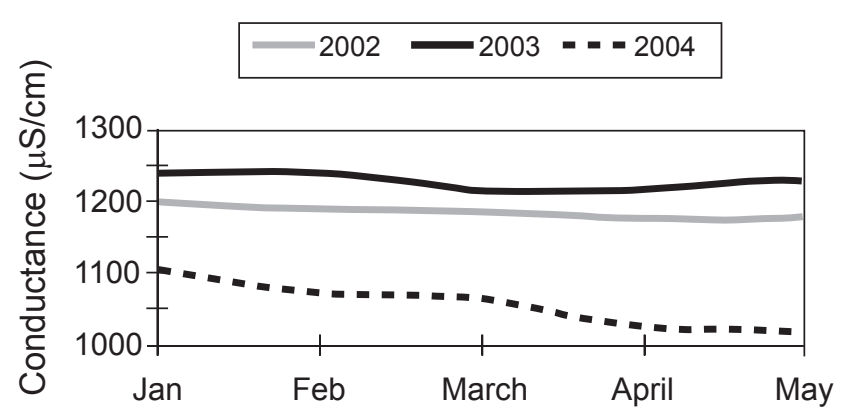

Fig. 62. Surface conductance $(\mu \mathrm{S} / \mathrm{cm})$ taken at Cibola High Levee Pond from 2002 to 2004.

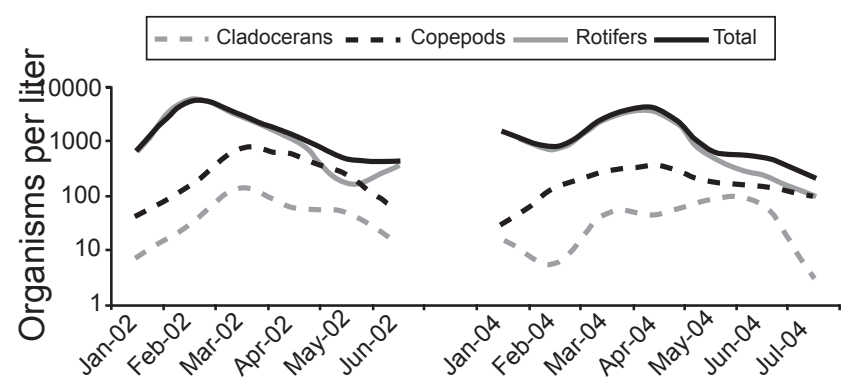

Fig. 63. Seasonal winter-through-summer cycle of the major zooplankton groups found in Cibola High Levee Pond. Data are presented as organisms/L based on vertical water column collections made from a depth of $2 \mathrm{~m}$ to the surface. 
Table 5. Total number of species, number of fish collected, and their composition (\%) from Cibola High Levee Pond from 20012005.

\begin{tabular}{lrl}
\hline \multicolumn{1}{c}{ Species } & n & $\%$ \\
\hline Bonytail (Gila elegans) & 1,441 & 63 \\
$\begin{array}{l}\text { Razorback sucker (Xyrauchen } \\
\text { texanus) }\end{array}$ & 800 & 35 \\
$\begin{array}{l}\text { Largemouth bass (Micropterous } \\
\text { salmoides) }\end{array}$ & 51 & 2 \\
$\begin{array}{l}\text { Bluegill (Lepomis macrochirus) } \\
\text { Channel catfish (Ictalurus } \\
\text { punctatus) }\end{array}$ & 2 & $<1$ \\
\hline
\end{tabular}

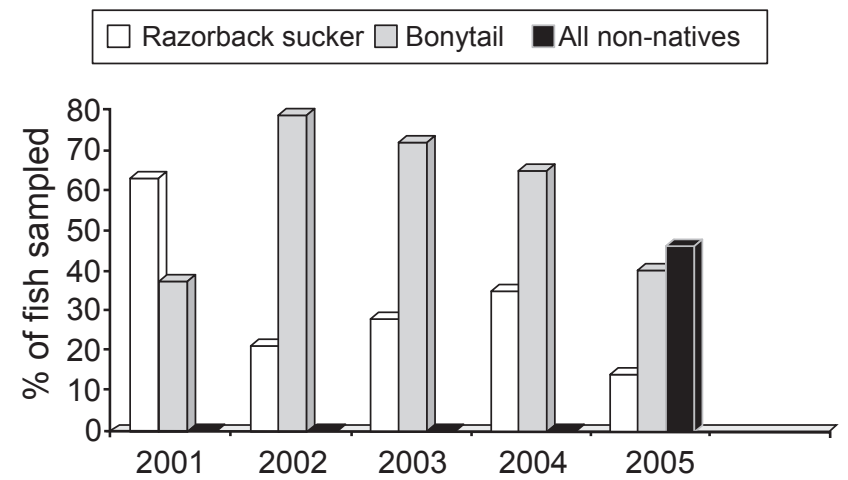

Fig. 64. Composition of the fish community at Cibola High Levee Pond from 2000 to 2005 ( $n=2,295$ fish).

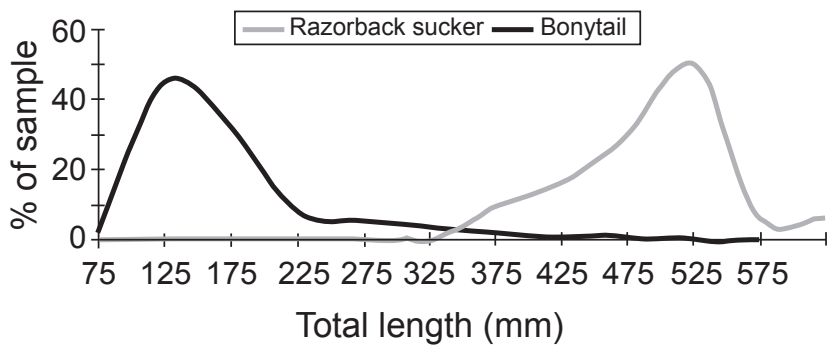

Fig. 65. Size distribution of bonytail $(n=1,440)$ and razorback sucker $(n=800)$ captured in Cibola High Levee Pond from 2000-2005.

older juveniles (3-4 years old) and adults. This imbalance could easily be manipulated and still maintain the community's genetic viability (Minckley and others, 2003). These large adults undoubtedly compete with younger year classes of both species for plankton, benthos, and invertebrates. Their removal and use at other areas could help free up food resources for small fish.

\section{Population Size}

Mark-recapture studies conducted in 2002 placed the fish community at an estimated 3,776 fish/ha with a biomass of
Tabel 6. Population estimates for bonytail and razorback sucker at Cibola High Levee Pond during 2002.

\begin{tabular}{lrrr}
\hline \multicolumn{1}{c}{ Species and range } & $\begin{array}{c}\text { Pool } \\
\text { estimate }\end{array}$ & $\begin{array}{c}\text { Range } \\
\mathbf{( 9 5 \% ~ C L )}\end{array}$ & $\begin{array}{c}\text { Density } \\
\text { (fish/ha) }\end{array}$ \\
\hline Bonytail & & & \\
$10-20 \mathrm{~cm}$ & 5,979 & $4,794-11,512$ & 2,600 \\
$>20 \mathrm{~cm}$ & 1,593 & $860-2,542$ & 693 \\
$\begin{array}{l}\text { Razorback sucker } \\
>20 \mathrm{~cm}\end{array}$ & 1,111 & $732-2,460$ & 483 \\
\hline
\end{tabular}

$552 \mathrm{~kg} / \mathrm{ha}$ (table 6). Bonytail numerically dominated (88.5\%) the community; however, razorback sucker constituted $67 \%$ of the pond's biomass. Volumetrically, standing crop was $3.5 \mathrm{x}$ $10^{-4} \mathrm{fish} / \mathrm{m}^{3}$ and $5.1 \times 10^{-5} \mathrm{~kg} / \mathrm{m}^{3}$.

\section{Bonytail Specifics}

We suspect bonytail successfully produced young until 2005 (figs. 66 and 67). Small $(<15 \mathrm{~cm})$ bonytail were more abundant than larger fish. Thousands of small fry were observed following spawning in 2001, 2002, 2003, and 2004. Schools of small juveniles $(<5 \mathrm{~cm})$ were commonly found hiding among debris along the shoreline or in submerged vegetation and the entrance of beaver dens. Figure 65 shows the size distribution as a percentage of fish caught. However, these data are biased due to the use of $1.2-\mathrm{cm}$ trammel nets in 2001 and 2002 and not in 2003 through 2005. Small trammel nets were dropped from the sampling protocol in 2003 due to problems of gilling large numbers of small bonytail. We switched to large minnow traps and hoop nets for the duration of the study in order to reduce stress and mortality. Alternate sampling methods proved less stressful but regrettably were far less effective in collecting the smaller year classes that were present (fig. 66). Very few small bonytail were captured using these alternative sampling techniques.

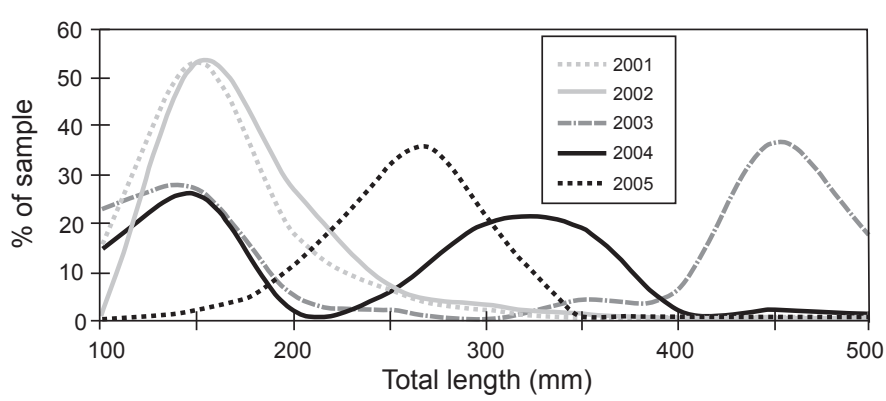

Fig. 66. Size distribution of all bonytail captured in Cibola High Levee Pond from 2001 to 2005. Values expressed are a percentage of the total sample. 


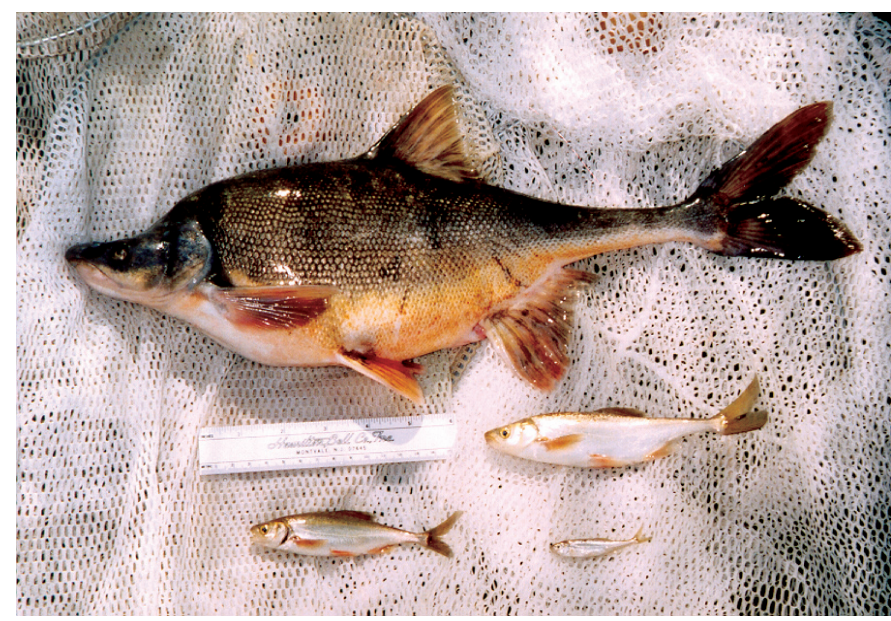

Fig. 67. Multiple year classes (possibly four) of bonytail captured in Cibola High Levee Pond, Arizona-California. These fish were all produced naturally in this pond.

\section{Spawning Sites}

Bonytail appeared to have a primary and three secondary sites where spawning behavior was either observed or fish eggs were found (fig. 68). Spawning was observed in 2002, 2003, and 2004 on a beaver trail that led over the river levee. This represented the primary location where spawning was observed and eggs and larvae were collected. Secondary locations, where fish were observed exhibiting spawning behavior or eggs were found at least one year, included similar sites along the river levee and the boat access ramp when the pond was exceedingly full (Mitch Thorson, USFWS, oral commun., 2003).

\section{Growth Rates}

Growth rates were calculated based on data taken from marked (pit-tagged) and recaptured fish collected a minimum of 9 months and a maximum of 24 months following initial release. The 9-month minimum described an annual growth season, while the maximum standard (24 months) reduced the conservative influence that occurs as fish age. Scale samples were collected from 76 small and intermediate-sized fish to help determine the year class structure of young fish.

Growth is typically the most rapid during early life, but for this community it appeared to peak for the 300 -mm-size group (fig. 69). Smaller-sized bonytail $(<200 \mathrm{~mm})$ exhibited a slightly smaller (-20\%) growth rate of $3.5 \mathrm{~mm} /$ month than medium sized (300-400 $\mathrm{mm}$ ) chub. Growth sharply declined as fish reached $400 \mathrm{~mm}$.

Slower growth in the younger cohort would not be normal and may represent an artifact of the small data set or retarded growth due to handling and marking stress (Paukert and others, 2005). Slowed growth due to dietary competition among small fish may also be a contributing factor. Quite possibly, competition for plankton by chub may be aggravated by direct competition from adult razorback suckers that share a similar diet. When larger bonytail shift their diet toward larger invertebrates and small fish, less competition and greater abundance in food will improve growth.

Female bonytail achieve greater body size: several exceeded $500 \mathrm{~mm}$, while all the males were $<490 \mathrm{~mm}$ in total length (fig. 70). Insufficient data exist to compare growth between the sexes, but female growth is either accelerated or continues at a later age compared to that of mature males. For example, the sex ratio of 350-mm bonytail was 1:1, however, that declined as fish size increased to a point where all fish $>500 \mathrm{~mm}$ were females (fig. 70). The maximum age of these bonytail would only be 13 years for fish initially stocked in 1993. Aging studies suggest the oldest fish examined was seven years old. Since longevity is $30+$ years, additional growth would be expected.

\section{Preferred Cover}

Telemetry studies suggested that bonytail used specific cover attributes found in the pond. For instance, large and intermediate $(>30 \mathrm{~cm})$ bonytail would conceal themselves in large riprap found along the high levee (fig. 71). They used this cover extensively during daylight hours and only came out at night to feed. Individual fish showed a high degree of fidelity to specific cavities (Marsh, 2004b).

Small $(<10 \mathrm{~cm})$ bonytail were commonly seen in the beaver den's entrance and hidden among vegetative and woody debris along the southern shoreline. They were especially fond of a tumbleweed drift row that extended along the river levee at depths $>2 \mathrm{~m}$ (fig. 71).

\section{Razorback Sucker Specifics}

Adult razorback suckers outnumbered young, but multiple year classes were represented (fig. 72). Recruitment was intermittent and individual year classes were typically small, making up $<10 \%$ of the fish handled (fig. 73). Youngof-year suckers were captured in 2003 and 2004, indicating young were produced the previous two years (2002 and 2003).

\section{Spawning Sites}

Spawning areas used by razorback suckers differed from areas used by bonytail. Spawning often caused sediment plumes, and repeated spawning events in the same area flushed fine sediments, leaving only clean gravel and cobble. The primary spawning site was located along the southern portion of the river levee (fig. 74). Spawning was observed at this location every year (2002-2005); during high water in 2002 and 2003, spawning behavior was also observed for fish located further north along the river levee.

\section{Growth Rates}

Information was analyzed for 86 suckers that were recaptured to determine growth rates at CHLP. Young fish exhibited the fastest growth ( $>6 \mathrm{~mm} / \mathrm{month})$; growth declined substantially when fish reached lengths of $>350 \mathrm{~mm}$ (fig. 75). Growth was similar for both sexes until they reached $450 \mathrm{~mm}$. At that 


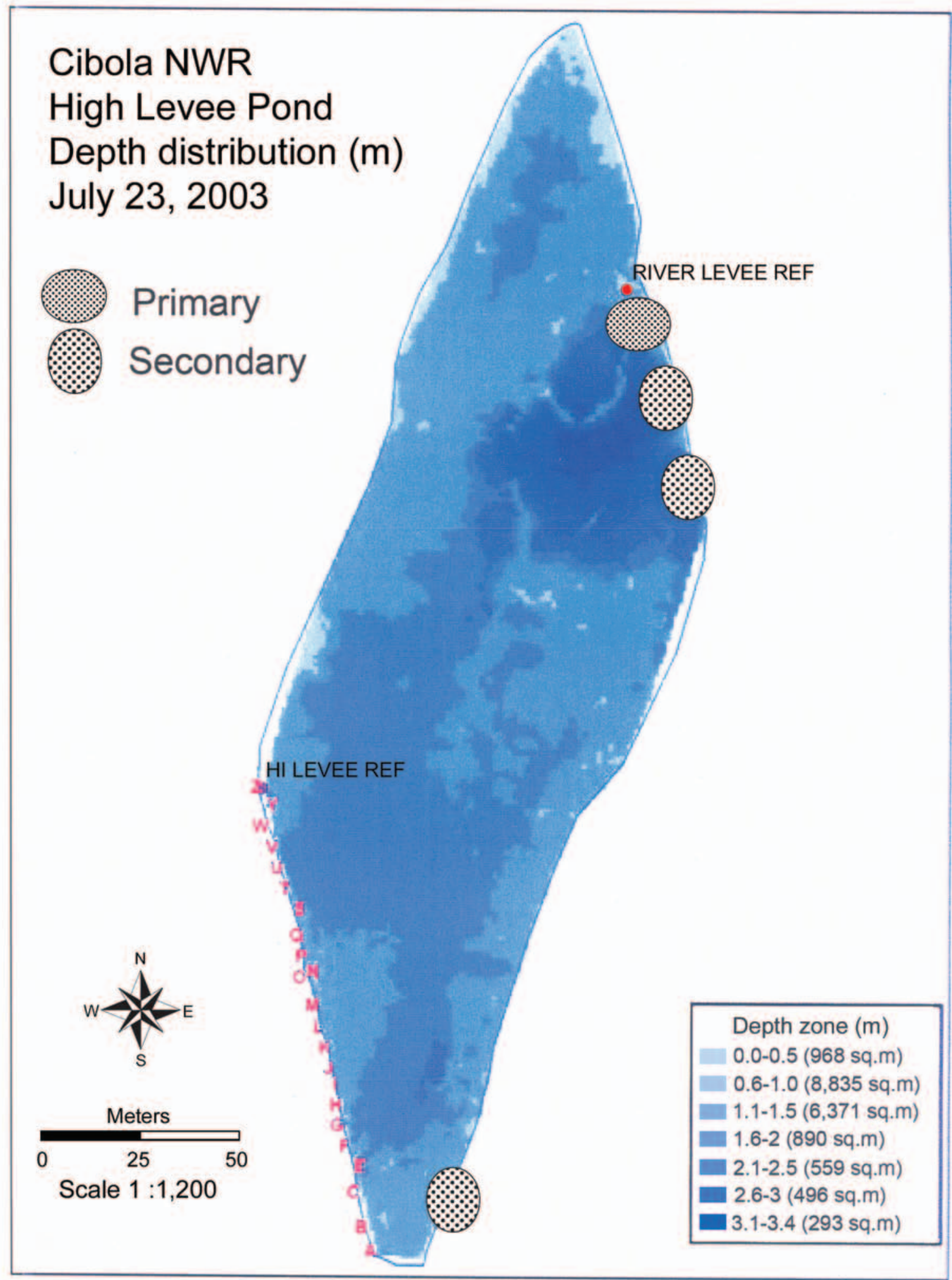

Fig. 68. Map of Cibola High Levee Pond showing the primary (red) and secondary locations where bonytail were observed exhibiting spawning behavior or their eggs were found. 


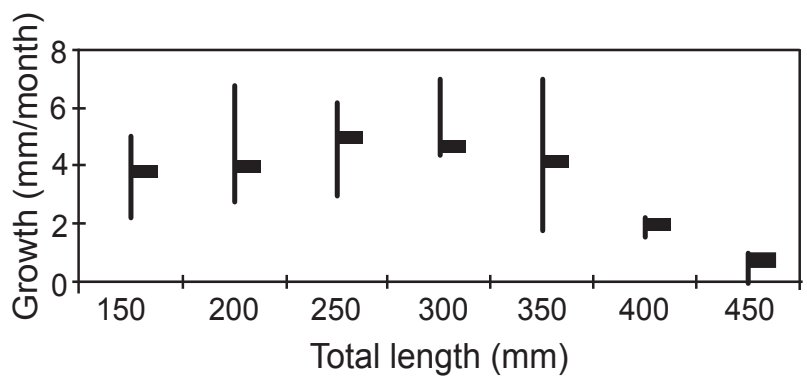

Fig. 69. Growth rates of bonytail $(n=31)$ taken from Cibola High Levee Pond based on 50-mm size groups. Vertical bars depict data ranges, and horizontal bars represent group average.

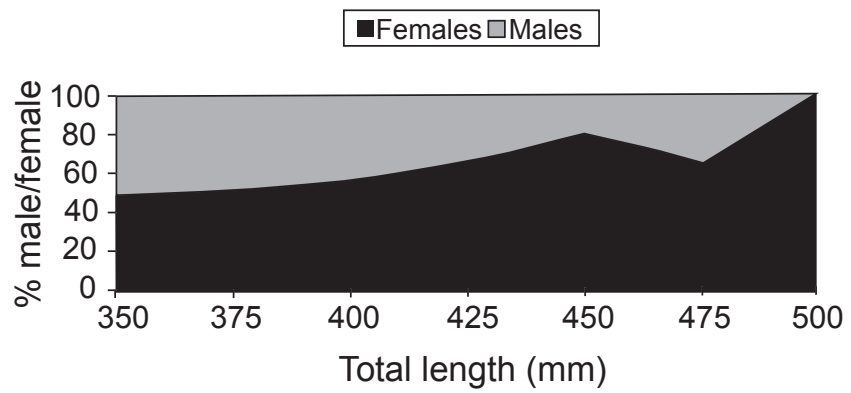

Fig. 70. The percentage of bonytail females versus males larger than $350 \mathrm{~cm}$ taken from Cibola High Levee Pond.

point, male growth appeared to slow ( $<1 \mathrm{~mm} / \mathrm{month})$ while female growth continued at $1 \mathrm{~mm} / \mathrm{month}$. The size advantage enjoyed by females appears to be gained as they become sexually active (third or fourth year).

The ratio of females to males was similar (1:1) for fish $<45 \mathrm{~cm}$. This ratio rapidly increased for larger fish in favor of females. Males can obtain lengths of $>60 \mathrm{~cm}$; however, with the relatively young nature of this community, all $(n=61)$ fish $>50 \mathrm{~cm}$ were females (fig. 76). With time, I would expect individuals of both sexes to gain additional growth and the shift in the proportion of sexes to occur at a much $(500 \mathrm{~cm})$ larger length.

\section{Habitat Preference}

I did not detect any habitat preferences for razorback sucker. Adults do not use cover, and young were scarce and were only captured during the night. No young suckers were ever observed while snorkeling. Young may use aquatic vegetation and tumbleweed debris located along the deeper portions of the river levee to hide, but this is speculation based on observations made elsewhere (Mueller and Marsh, 1993, 1998).

\section{Other Animal Communities}

Cibola National Wildlife Refuge is an important waterfowl sanctuary and is frequented by resident and migrating birds associated with aquatic habitats (e.g., kingfishers, osprey, cormorants, pelicans, ducks, night herons, great blue herons). Raccoons and small rodent dens are present in the high levee.
Staff has seen bobcats (Felis rufus), mountain lions (Puma concolor), coyotes (Canis latrans), and white-tailed deer (Odocoileus virginianus) along the levees.

Beaver have an active colony, and several bank dens existed along the northwest and southeastern (old) shorelines. The animals have well-established trails over the river levee, where they move freely back and forth from the pond to the river. The beaver trenched and cleared entrances through the cattail community. These trenches are impressive; some measure $1 \mathrm{~m}$ each in depth and width and extend $>10 \mathrm{~m}$ in length.

The pond also supports a large population of bullfrogs (Rana catesbeiana) and the red swamp crayfish (Procambarus clarki), both introduced species. The pond supported several dozen adult bullfrogs and, based on underwater videography, approximately 60,000 tadpoles. As described in other sections of the report, crayfish were a constant problem when sampling fish. Crayfish climbed trammel nets, invaded minnow traps, and fed on the soft body tissues of captured fish.

\section{Factors Contributing to Successful Recruitment}

Cibola High Levee Pond was the only place in the river basin where recruitment of these two native species has been documented in three to five decades (Pacey and Marsh, 1998). The factors promoting recruitment in CHLP are complex, but the most obvious are the low number or absence of nonnative fish predators. In river habitats, predation appears to be the primary factor preventing recruitment. Nonnative fishes were absent in all cases where natural recruitment was sufficient to support a community. The factors judged to aid reproduction at CHLP are listed in their order of importance:

1. Nonnative predatory fish were rare. Nonnative fishes constituted less than $0.01 \%$ of the fish sampled from CHLP. Of those found, the vast biomass were large individuals ( $>2 \mathrm{~kg}$ ) that would be unlikely to feed on eggs or larvae. However, native fish young disappeared in 2004 when young bass became abundant (47\%) following a largemouth bass spawn.

2. Size. The pond's small ( $<3 \mathrm{ha}$ ) size increased the likelihood of complete renovation and appears to have reduced the frequency of reintroduction by being less attractive to anglers. It also increased the ability of managers to detect and control exotics.

3. Water quality. Ground water or levee infiltration circulates through CHLP toward Pretty Water. This circulation appears to maintain acceptable water quality that typically mimics river conditions. The only exception is temperature: the pond is about $4-5^{\circ} \mathrm{C}$ warmer than the river during the summer.

4. Habitat complexity. The pond's substrate is highly diverse, ranging from boulders, large rock, and gravels to fine silts that provide ample spawning substrates. Vegetation, such as pond weed (Potamogeton spp.), 


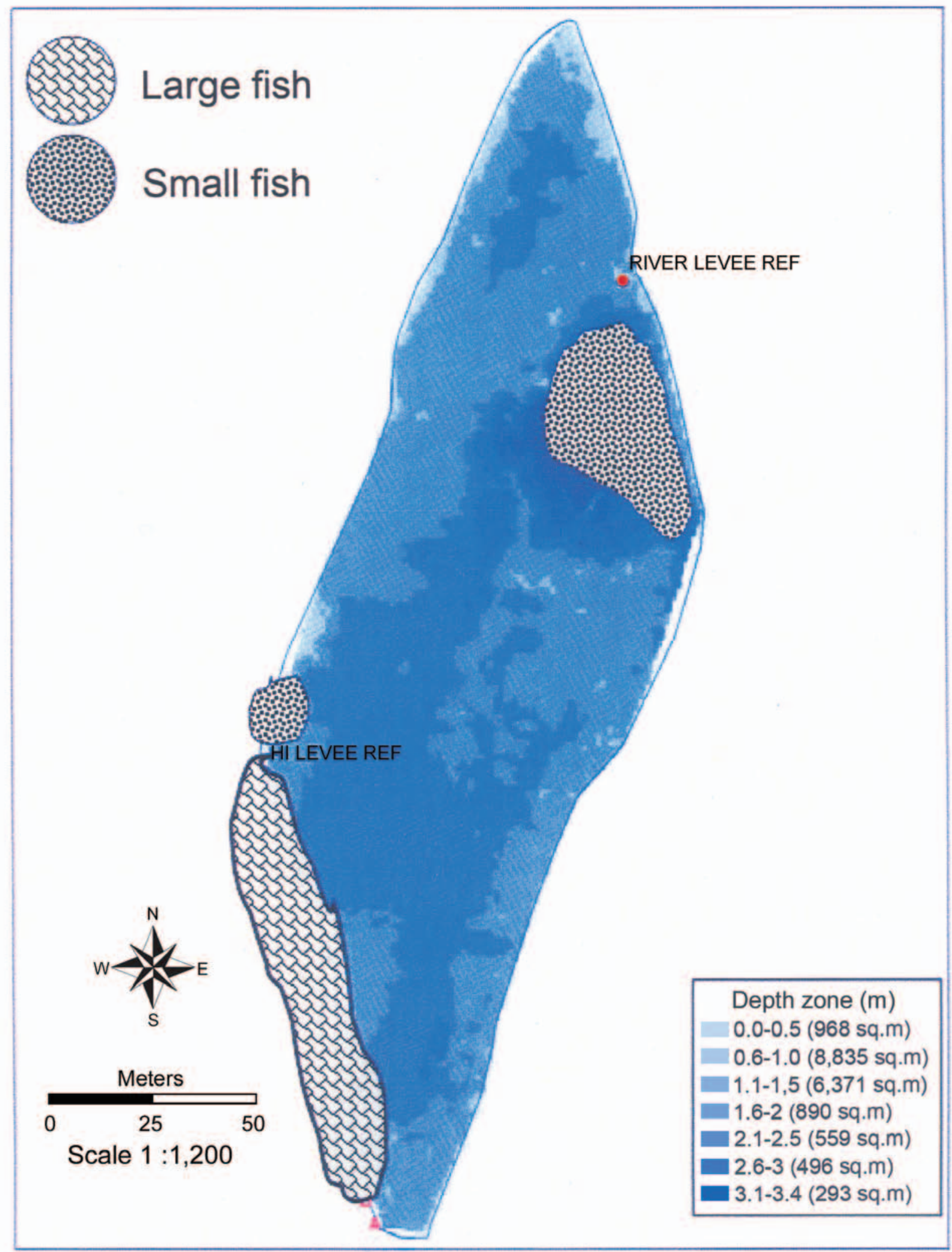

Fig. 71. Map of Cibola High Levee Pond showing areas of cover used by large $(>30 \mathrm{~cm})$ bonytail and smaller $(<20 \mathrm{~cm})$ bonytail. 


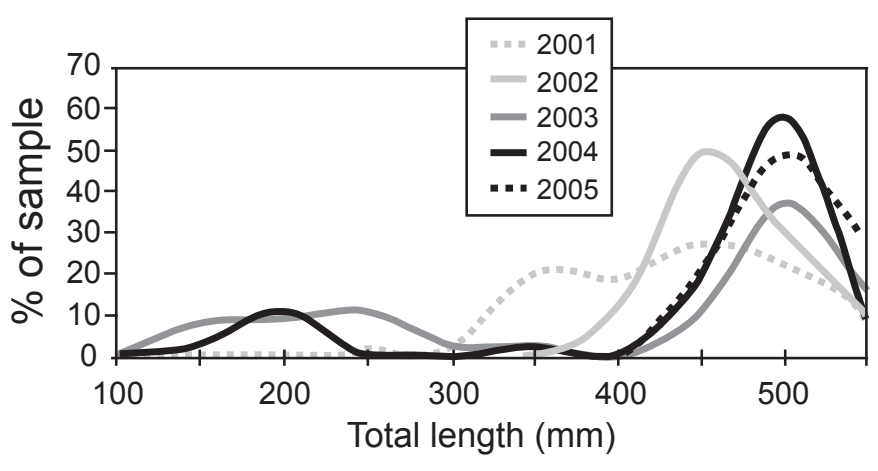

Fig. 72. Size distribution of razorback suckers captured in Cibola High Levee Pond from 2001 through 2004 using all types of sample gear. Values expressed are a percentage of total sample.

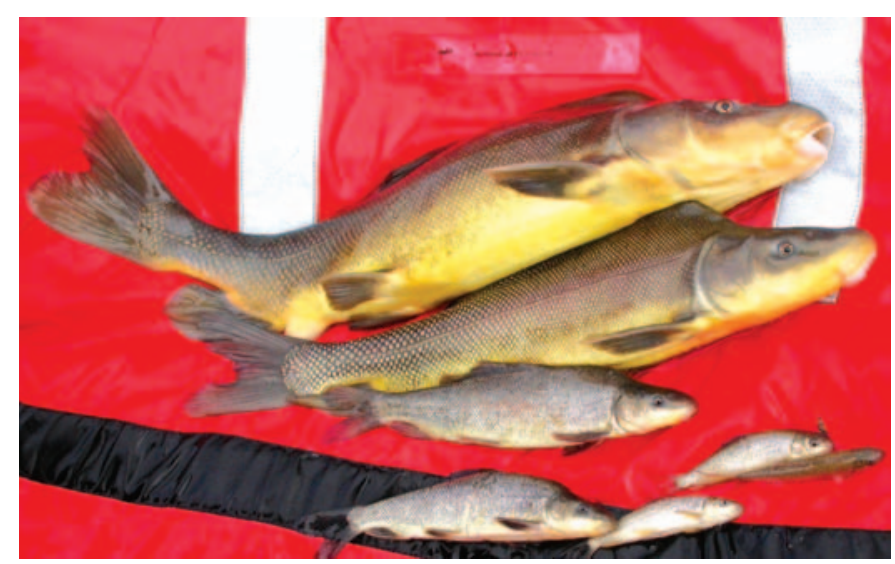

Fig. 73. Multiple year classes (possibly four) of razorback sucker captured from Cibola High Levee Pond, Arizona-California. These fish were all produced naturally in this pond.

emergent cattail (Typha spp.), and shoreline brush, provides structure. Bank depressions, beaver dens, and large riprap offer a wide range of cover types. Water depth is generally shallow $(<2 \mathrm{~m})$, but a deeper area $(>3.5 \mathrm{~m})$ provides refuge from the summer heat.

5. Mixed community. The fish community initially contained two native fish species, one of which is a native omnivore that will consume fish (Marsh and Schooley, 2004). Red shiner, mosquitofish, and early life stages of other nonnatives were absent. Large predatory bonytail may also have helped reduce bullfrog and crayfish numbers (Lenon and others, 2002).

\section{Predation Is the Issue}

This study supports the belief (Pacey and Marsh, 1998; Minckley and others, 2003) that predation by nonnative fishes is the primary cause for recruitment failure for these species. In addition, the speed (one year) in which largemouth bass recolonized and replaced natives in CHLP was sober- ing and illustrates the severity of the problem. Nonnative predators aggressively feed on native fish (figs. 77 and 78). Scheeler (2002) reported a similar situation for Oregon chub (Oregonichthys carmeri), which benefited from isolation when separated from nonnative fishes.

Nonnative fish comprised less than $0.5 \%$ of the fish community up until 2004 , but the pond still contained a multitude of predators, including several nonnatives (i.e., bullfrogs, crayfish, and several fish species). We believe there is a high likelihood many of these exotics were stocked by fishermen. Osprey and kingfishers were observed feeding on bonytail and razorback suckers, and we discovered that nonnative crayfish and bullfrog tadpoles also contributed to fish losses (Mueller and others, 2003a).

Predation is typically associated with larger predators, whereas recruitment failure is seldom associated with small predators. Juvenile bonytail readily feed on razorback sucker larvae, and adult razorback suckers frequently raid bonytail spawning beds, presumably to feed on their eggs (Mueller and others, 2002). Videography revealed the pond was heavily infested with bullfrogs and their tadpoles as well as red swamp crayfish. Tank tests revealed both fed on fish eggs and larvae; crayfish also fed on larger fish that they aggressively pursued (Mueller and others, 2003a).

So, it became evident these fish could successfully survive and produce young even at some level of predation. Unfortunately, we simply did not have the means to determine what the predation rate was; but apparently, it is lower than what is occurring in the wild, where natural recruitment is either totally missing or inadequate to maintain relic populations.

\section{Cibola High Levee Pond Future}

The success of CHLP could not be expected to continue indefinitely. As Minckley and others (2003) pointed out, this type of community is temporary: they will eventually be invaded by nonative fishes and must be managed accordingly. Threats posed by the introduction of largemouth bass were evident by July 2004, when I discovered that largemouth bass had successfully spawned in CHLP. Somehow, 6-10 adults (estimated from snorkeling) found their way into the pond and produced thousands of offspring. Hundreds of small $(2-3 \mathrm{~cm})$ young-of-year bass were distributed pond-wide, and by 2005 , largemouth bass comprised $47 \%$ of the fish caught. Literally hundreds of bass were observed in schools, most about $10 \mathrm{~cm}$ in length.

We have been extremely fortunate that the community has maintained a relatively healthy population of native fish for more than a decade. For some reason, nonnatives were unable to reestablish in any significant number. Undoubtedly, the initial renovation was successful and sampling continued to remove small numbers of large game fish. However, it only takes a single mating pair to compromise the security of a native community. 


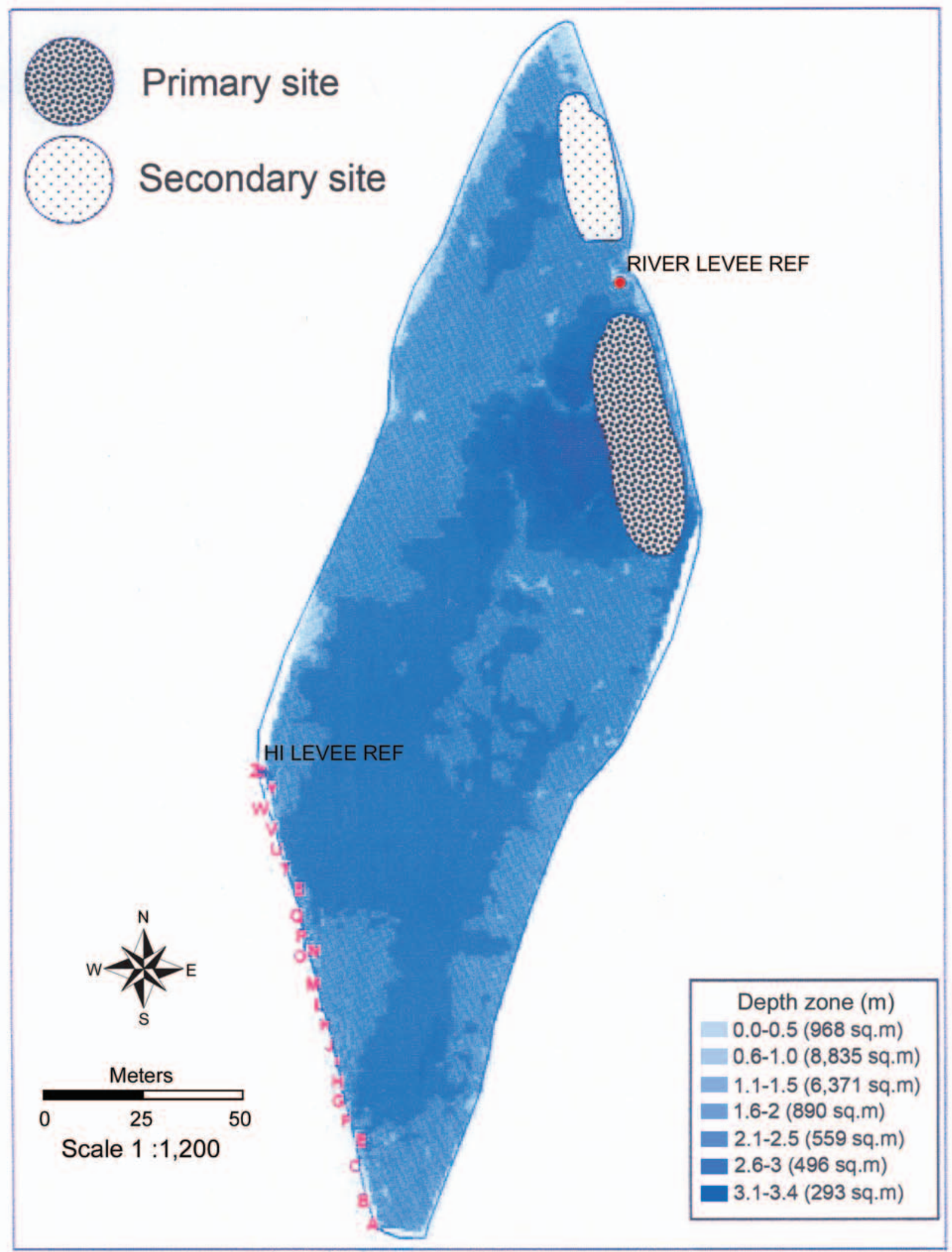

Fig. 74. Map of Cibola High Levee Pond showing the primary and secondary locations where razorback sucker were observed exhibiting spawning behavior and their eggs were found. 


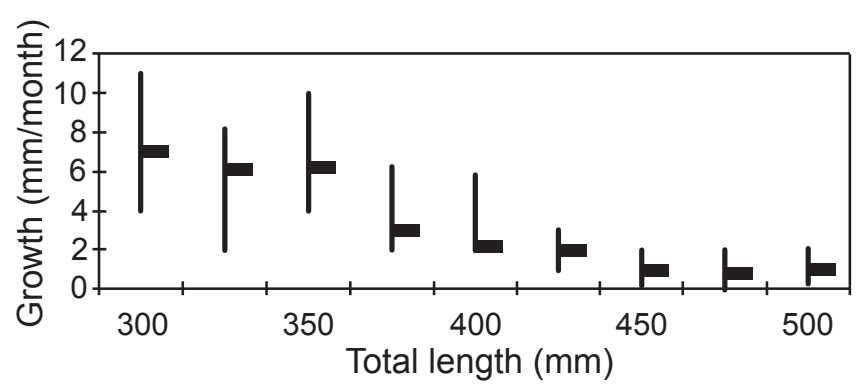

Fig. 75. Growth rates of razorback suckers $(n=86)$ taken from CHLP based on 25-mm-size groups. Vertical bars depict data ranges, and horizontal bars represent group average.

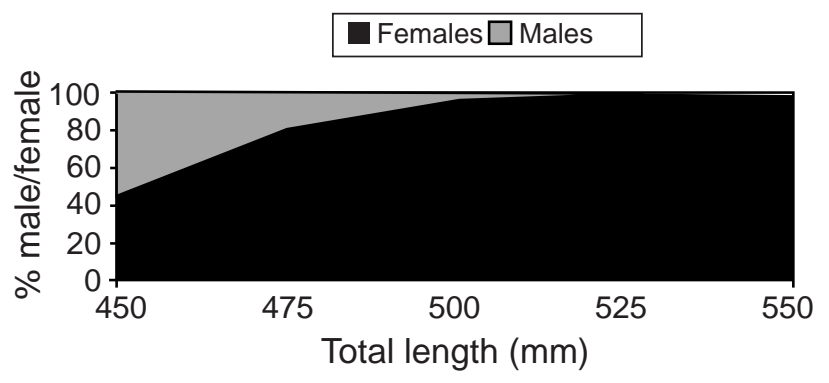

Fig. 76. The percentage of females versus males for razorback sucker larger than $450 \mathrm{~cm}$ taken from Cibola High Levee Pond.

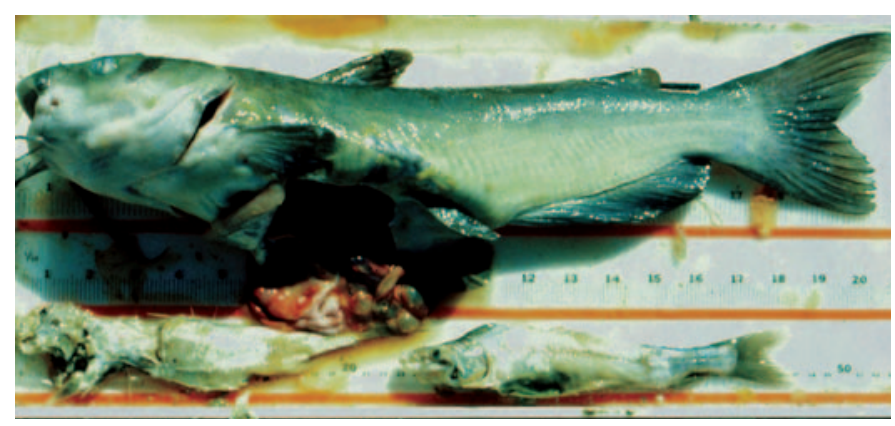

Fig. 77. Photograph showing the stomach contents of a channel catfish captured a few hours following the stocking of razorback sucker in Central Arizona. Both partially digested fish were razorback sucker. Photo courtesy of Paul Marsh, Arizona State University.

\section{Management Plan}

Cibola High Levee Pond is managed under the overall management guidelines of the refuge. Currently, CHLP represents a curiosity, a phenomenon recognized for its importance. There is no specific management plan or identified purpose for this pond other than the initial 1993 goal of raising bonytail and razorback sucker for eventual stocking. This needs to be reevaluated.

A plan could be developed that incorporates management, research, and conservation components, as outlined by Minckley and others (2003), in concert with the recently drafted Lower Colorado River Management Plan (USFWS,

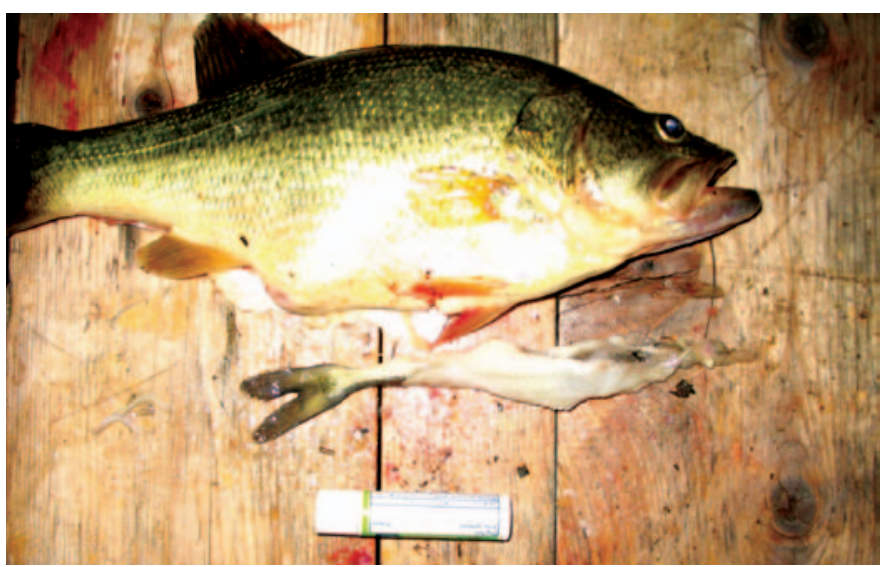

Fig. 78. Photograph of largemouth bass capture from Cibola High Levee Pond during the spring of 2005 containing the remains of bonytail. Photo courtesy of James Lee, Arizona State University.

2004). A wealth of experience, thought, and science went into the development of both plans.

\section{Management Options}

Management options for CHLP include the following:

- Expand the autumn electrofishing effort to 2 weeks, including intensive netting to salvage as many native fish as possible:

- move bonytail to another secure habitat (e.g., Davis Cove);

- move razorback sucker to appropriate locations.

- Chemically renovate CHLP during low water:

- take steps to resuscitate remaining natives.

- Restock the pond with multiple year classes of bonytail and razorback sucker in early spring, using

- 5,000 15-cm bonytail and

- 2,500 30-cm razorback suckers.

- Develop a management plan that incorporates

- monitoring protocols;

- nonnative threshold criteria that would increase detection and trigger native salvage efforts;

- harvest of surplus fish and relocation incorporating genetic protocols;

- identification of containment locations for broodstock; and

- chemical renovation and restocking protocols.

- Set harvest criteria so surplus fish that become available (when populations exceed 5,000 [>15 cm] bonytail and $>500$ large $[>50 \mathrm{~cm}]$ razorback sucker) can be used effectively.

- Designate CHLP as a research field station for local high schools, colleges, and universities. Support continued research in pursuit of the following: 
- native fish management;

- predator/prey research; and

- graduate student projects.

- Develop public outreach and interpretive programs:

- post additional signs and consider fencing access;

- develop special interpretive programs.

- Integrate the construction of similar pond communities into the basin's wildlife refuge management plans.

\section{Physical Habitat Improvements}

Studies have shown the importance of large rock cover for intermediate and large-sized bonytail. Bonytail are either dependent on or have a high preference for dark, overhead cover. Currently, bonytail traverse through shallows when they leave from and return to their daytime sanctuary. During low flows in the winter, water depths in this area are seldom $>50$ $\mathrm{cm}$. The dark dorsal surface of these fish is contrasts with the light substrate, making them highly visible and vulnerable to avian predators. Herons "fish" from the riprap, waiting to strike fish leaving or entering the riprap. Accumulations of bird droppings mark popular feeding stations. The incidence of dorsal scars and recent wounds indicate avian predators are very successful (fig. 79). There is also evidence that raccoons, ringtail cats (Bassariscus astutus), and other fish-eating animals use the levee.

Several steps could be taken to improve fish access and reduce predation. Large riprap or dense brush piles could be

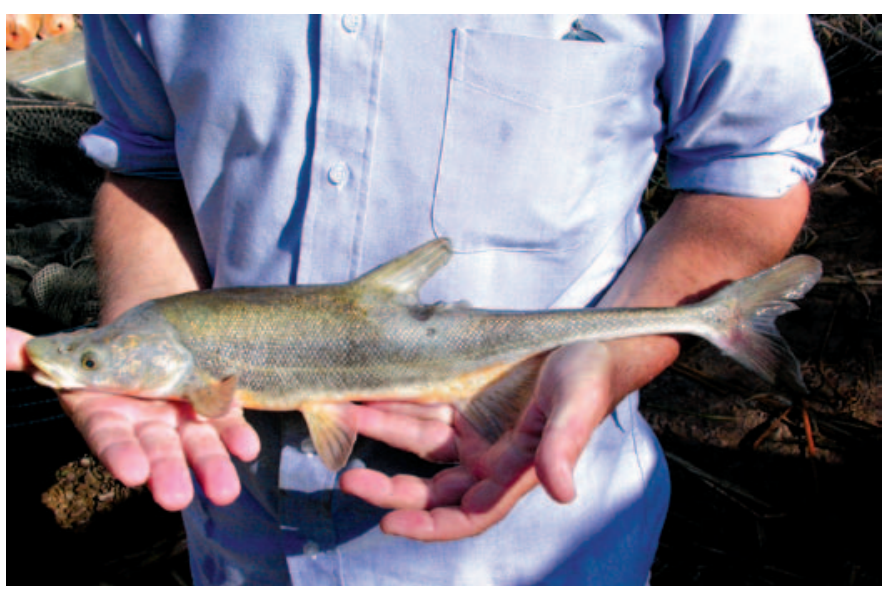

Fig. 79. A large bonytail taken from Cibola High Levee Pond exhibiting a large healed wound on its back, with part of its dorsal fin missing. This wound occurred between captures.

placed in a few strategic locations along the river levee. This would not only provide bonytail with additional cover, but it would be located adjacent to deeper water. These locations include the extreme southern corner of the river levee and the spit of land just north of the area where bonytail currently spawn.

The information sign, which sits on top of the high levee, is commonly used as a perch by osprey. This location gives these birds a perfect vantage point to observe fish in the shallows. I have witnessed osprey attempting to take fish from this sign. Moving the sign or adding avian spikes to prevent birds from perching could reduce this source of predation. 


\section{Chapter 3. Oxbow Communities: The Missing Key to Recovery?}

Natural floodplain wetlands in the Colorado River have been greatly reduced by river channelization, dewatering, and development of the floodplain. The historical importance of floodplain habitats for young Colorado River fishes is widely recognized. For decades, biologists have searched for ways to restore natural recruitment by manipulating flows in order to reconnect the river to its floodplain (Burdick, 1994; Irving and Burdick, 1995; Tyus and Karp, 1990; Modde, 2005). However, the importance of floodplains to adults (McAda and Wydoski, 1980; Bradford and Gurtin, 2000) is often overlooked.

Connectivity of these habitats was an essential component in these fishes' recruitment strategy (Maddux and others, 1993). Today, the river basin is full of nonnative fish predators that thrive in these habitats (Tyus and Saunders, 2000; Mueller, 2005). Predation is a pivotal problem which has spurred numerous predator removal programs (Lentsch and others, 1996; Modde and Fuller, 2002). Unfortunately, these programs have failed to benefit native communities (Mueller, 2005). The sobering truth is that for all practical purposes, wild populations of bonytail are extirpated and razorback sucker populations are nearly so.

There is little argument that water development and its associated modification of natural flow patterns can be detrimental to stream health (Stanford, 1994). An institutional mind-set persists that Colorado River fishes must have specific flows to complete their life cycle (Maddux and others, 1993; McAda, 2003). Little credence has been given to the fact that in the absence of introduced fishes, bonytail and razorback sucker also can thrive in ponds. There is substantial evidence that this was an evolutionary skill, a survival strategy that allowed them to cope with whatever harsh and unpredictable conditions the river presented, yet complete their life cycles in these highly contrasting habitat types. The fact that they can reproduce in lentic habitats provides an opportunity for managers to separate these fish from the nonnative predators that continue to block recruitment in the mainstem river (Minckley and others, 2003).

\section{Historical Evidence}

There is evidence that bonytail and razorback sucker were abundant in ancient Lake Cahuilla when the Colorado River periodically filled the Salton Sink. The last natural event occurred about 700 A.D., at which time the Salton Sink filled completely, forming an inland lake covering more than 10,000 $\mathrm{km}^{2}$ (Waters, 1981). Anthropologists have uncovered hundreds of bonytail and razorback sucker bones in ancient rock fish traps and fire pits, suggesting that these fish were once a major component of that lake's fishery (Schaefer, 1986). Villages of American Indians thrived on the lake's fishery for 20 generations (Wilke, 1980).
In recent times, razorback sucker, and to a lesser extent, bonytail, established notable populations during the initial filling of several Lower Basin reservoirs (Minckley, 1983). Populations were established in Lake Roosevelt, Lake Mead, Lake Havasu, Senator Wash Reservoir, and Lake Mohave (Minckley and others, 1991). Initially these communities numbered in the hundreds of thousands, and many of these fish were commercially harvested prior to 1950 (Minckley, 1973; Mueller and Marsh, 2002). Recruitment during the initial flooding or filling stages of these mainstem reservoirs was impressive but only lasted a few years before expanding predator populations prevented further recruitment (McCarthy and Minckley, 1987). Relic populations eventually died off from old age and are either absent or nearly gone today.

Since the development of a bonytail broodstock in 1981, hatcheries have been faced with the problem of "volunteer spawn." Annually, tens of thousands of fish originating from volunteer spawn in holding ponds are destroyed due to their unknown parentage (Quent Brandwisch, UDNR, oral commun., 2005; Manuel Ulibarri, USFWS, oral commun., 2005). This problem is common for bonytail more than a year old that are held in outdoor rearing ponds. They do not require flow to successfully spawn, only some type of clean substrate for their eggs to adhere to, mature and hatch, and the absence of nonnative predators.

Cibola High Levee Pond's community was unique only because it contained both bonytail and razorback sucker. Bonytail and razorback sucker natural recruitment has been well-documented for monocultures (Pacey and Marsh, 1998). Razorback suckers have successfully produced young at Yuma Cove (fig. 80), at the Grand Valley Facility rearing ponds on the San Juan River (Dale Ryden, USFWS, oral commun., 2005), and a minimum of four generations at Rock Tank at Buenos Aires National Refuge (fig. 81) (Marsh, 1987b; Marsh,

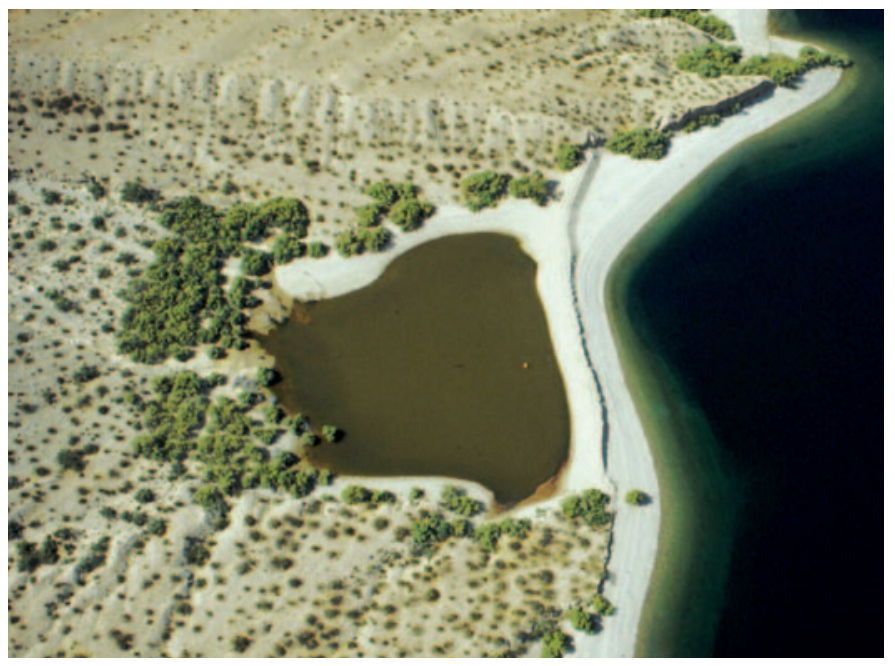

Fig. 80. Yuma Cove is located on Lake Mohave (Arizona-Nevada). Wave action combined with beach erosion formed a natural sand spit across the mouth of this inundated backwater. The backwater was totally isolated during low reservoir elevations but reconnected at high reservoir elevations. The sand spit was heightened and enlarged to permanently isolate the pond in order to raise razorback sucker (Mueller, 1995). 


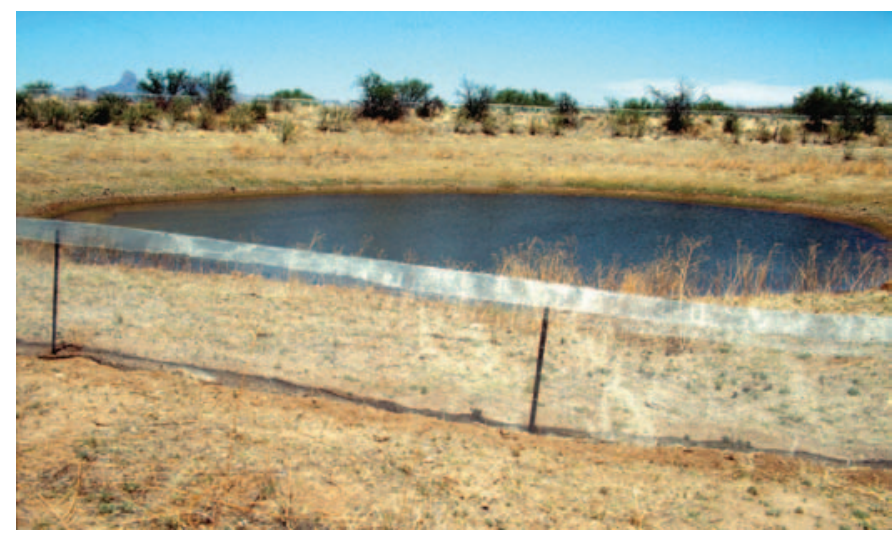

Fig. 81. Rock Tank is located on the Buenos Aires National Wildlife Refuge in southern Arizona. It represents one of three ponds stocked with razorback sucker. Fish did not survive in the other two ponds but successfully produced four year classes in Rock Tank before they were removed. (Wire fence is an amphibian barrier.) Photo courtesy of Dale Turner, The Nature Conservancy.

ASU, oral commun., 2005). These communities illustrate that neither species is hampered by lentic conditions, and the key to recruitment and survival is absence of nonnative fishes. If nonnative fishes had not been introduced, it is highly probable that today's reservoirs would be supporting populations of bonytail and razorback sucker; they certainly would not be fishless (Minckley, 1983).

The ecological significance of small sanctuary populations was described by Douglas and others (2003) who recently examined the molecular variability in flannelmouth sucker (Catostomus latipinnis). The lack of genetic variation in this species suggests they suffered near extinction declines, the most recent at the end of the Pleistocene. This is unusual, given their fossil history and broad distribution. Intense drought during that period not only impacted large mammals but also larger fishes in the southwestern United States. These fish were reduced to a very small number about 7,500 years ago, illustrating the environmental peril these fish faced and the importance of these "seed" populations in the survival of the species.

\section{A Need and an Opportunity}

Unfortunately, it is not difficult to trigger a philosophical debate on what refuge populations represent, especially to those not familiar with the ecology of desert streams. The more opinionated would argue that sanctuaries provide recovery, and their creation should allow further development of the resource. Some environmentalists are opposed to the concept, suggesting they represent a compromise or threat to the ecosystem and simply represent "zoo populations" (Alagona, 2004). It appears that isolated lentic systems were part of the historic Colorado River system. Today, these habitats are more or less gone, and those that remain are filled with nonnative predators (Burdick, 2002; Osmundson, 2003; Mueller, 2005). The ability of bonytail and razorback sucker to thrive in isolated lentic habitats provides a unique opportunity that should be used in their conservation and recovery.

Researchers (Marsh 2004a; Clarkson and others 2005) recently pointed out that the absence of success in many recovery programs is the result of attempts to maintain coexisting native and recreational fisheries. In contrast, sanctuary populations have been instrumental in the conservation and preservation of many native fish species because in each case, isolation from introduced fishes was essential for success (Williams, 1991; Moyle and Sato, 1991). Examples include the Devil's Hole pupfish (Cyprinodon diabolis), Gila topminnow (Poeciliopsis occidentalis), greenback cutthroat trout (Oncorhynchus clarki stomias), Apache trout (Salmo apache), and Gila trout (Salmo gilae) (Rinne and Turner, 1991).

Because native-fish recovery programs in large mainstem streams often conflict with established and economically important recreational fisheries, state agencies are caught in a predicament. The reduction or elimination of sport fisheries directly impacts fishing license sales, a source of agency funding. The solution has been to try to manage both native and recreational fish in the same waters. More than two decades of that philosophy has supported license sales but failed to solve either the biological or the political problems with threatened fishes (Clarkson and others, 2005). Simply put, the resources and effort invested in managing native communities are not the same as those invested in managing recreational fisheries (Clarkson and others, 2005).

\section{The Opportunity}

Sanctuaries represent a historical habitat component that is available to secure the species from catastrophic loss while providing managers and researchers opportunities to learn more about these species. Minckley and others (2003) described in detail the designs and management benefits of refuge communities. Their conservation plan for the Lower Colorado River takes into account conservation goals, management of the gene pool, and the production of larger fish for adjacent waters. The plan stemmed in part from the recruitment success witnessed at CHLP. The ultimate challenge is to have this plan adopted and implemented as a resource management strategy not only in the Lower Basin, but basin-wide.

Isolated oxbows that were part of these fishes' historical habitat and today provide our most effective method of developing predator-free conditions for native communities. These facilities also provide opportunities for both researchers and managers to advance conservation and recovery programs. We need to develop the skills necessary to manage these species on a realistic scale before we embark on more ambitious programs in the river. Today, it is not known if full recovery is technically or economically feasible on the entire river.

Cibola High Levee Pond represents one of the few instances during the past five decades where natives have actually developed a self-sustaining population. In 2002, CHLP supported all $(7,500+)$ of the wild-born bonytail and 
half $(1,000+)$ of the wild razorback sucker that existed in the wild. This is in stark contrast to the extirpation of wild populations in the river. Nearly two decades of recovery efforts have failed to recover, let alone reverse, the overall decline of these fish. Sanctuary communities provide the means to develop and refine management skills necessary for more ambitious recovery efforts.

\section{Research and Management Roles}

Facilities necessary to conduct complex and long-term predator-prey experiments are not being built, nor are they supported by recovery programs in the Colorado River Basin. Fundamental questions are not only going unanswered, it appears many are being ignored for political expediency (Brower and others, 2001).

For instance, it would be prudent to determine the level of predator removal needed to restore native recruitment on a small scale before large-scale removal programs are implemented. Specifically, is mechanical removal and predator control feasible on the scale necessary to invoke a possible response by native communities? This question is not being tested in a systematic, scientific, or economic manner. During the past decade, millions of nonnative fish have either been killed or removed at the cost of millions of dollars without programs first identifying what level of treatment or control is actually necessary to meet anticipated goals (i.e., recovery) (Mueller, 2005). Sanctuaries provide researchers and managers opportunities to effectively research questions and refine management expertise while minimizing conflicts with the recreational angler. Refuge communities can allow systematic and long-term research under conditions that can be controlled and effectively studied and tested. If mechanical predator control is not effective in a 10 ha pond, it is certainly is not going to work in $100 \mathrm{~km}$ of river.

Variable flows (e.g., droughts, floods) combined with the scarcity or even absence of targeted species has plagued research efforts in the wild for nearly three decades, making it difficult to conduct meaningful research. A recourse would be the construction of ponds and the management of a series of native communities (Clarkson and others, 2005).

\section{What is Realistic?}

\section{Current Status}

Cibola High Levee Pond was compromised when, in 2004, introduced largemouth bass spawned and recolonized. Today, the pond contains several thousand bass, and small native fish have become either absent or exceedingly rare. To my knowledge, there is no natural recruitment of bonytail or razorback sucker in the wild. Preliminary attempts to secure clearances to chemically renovate CHLP have met resistance from state environmental protection authorities (Chuck Minckley, USFWS, oral commun., 2005).
The U.S. Fish and Wildlife Service, Region 2, is working with the Bureau of Reclamation to build 160 ha of refuge habitats in accordance with recommendations provided in a biological opinion (USFWS, 1997). Beal Lake and the Imperial Native Fish Ponds were dredged and modified for this purpose. Funding was provided to renovate, stock, and develop these communities. Beal Lake was renovated and stocked with 10,000 wild razorback sucker juveniles in 2002 (Brouder and Jann, 2004). Similar actions were taken at Imperial Native Fish Ponds in 2003. However, nonnative fishes repopulated the pond, resulting in no natural recruitment (stocked fish were immature), and few of the stocked razorback suckers survived. A smaller portion (10 ha) of Imperial Native Fish Ponds was isolated, renovated and restocked and those fish have survived and grown.

Large ponds are undoubtedly more economical to build compared to more numerous, but smaller, ponds. However, in reality, a 100-ha native fish community is many times more vulnerable compared to 10 smaller ponds. While large facilities may be far cheaper to build, they can be more biologically and economically costly to manage, especially if they are invaded more frequently by unwanted fishes and require repeated salvages and renovations. It only takes one pair of mating fish to compromise a native community regardless of its size.

Unfortunately, a great deal of resources have been expended, but we have seen little progress in expanding, let alone maintaining, the CHLP community. These failures can be attributed to (1) inadequate resources necessary to prevent or suppress recolonization, (2) reluctance to stock sexually mature adults, and (3) regulations that were developed to protect the environment, but hamper the effective management of imperiled species. It is time to reassess what is realistic in terms of management goals.

\section{Management Issues}

Construction of refuge communities is proving a daunting task, but the greatest challenge will be effective, long-term management. We continue to ignore the consequences of the nonnative fish problem by not committing adequate resources to remove or control predators. Past failures emphasize the need to develop facilities that are easy to manage and less prone to catastrophic loss. Facility drainage (gravity or pumps) is essential to allow for effective salvage and renovation. We need to rethink our approach and its scale, and prioritize issues. A combination of three types of refuge communities, with the differences lying in physical size, use, and overall cost, will help solve the problem.

1. Medium-sized (2-5 ha) ponds would optimize native community health as outlined by Minckley and others (2003). The goal should be to establish and maintain healthy populations while refining management techniques. This would require the refinement of management plans detailing monitoring needs, necessary 
population manipulations (i.e., harvest, stocking), and protocols that would trigger fish salvage and renovation when nonnative recolonization or fish health issues reach epidemic proportions.

2. Small ( $<1$ ha) ponds can be used to conduct controlled experiments. Ponds would be of an appropriate nature to allow bonytail or razorback sucker to spawn and produce young. These communities could then be used to test predator-prey interactions in a controlled and long-term setting.

3. Large ponds have been built in the Lower Basin to establish native communities. They also exist in the Upper Basin (i.e., Old Charlie Wash) and have been used to test flow manipulations. Successful techniques developed in smaller ponds can be tested in larger habitats for eventual application to even larger geographical areas. For instance, if sanctuary protocols are successful for small $(<2 \mathrm{ha})$ ponds, then the program should next be expanded to larger bodies of water and ultimately move toward restoring stream populations.

\section{New Sanctuaries}

Additional communities based on the guidelines outlined in Minckley and others (2003) could be created. The two most important criteria for new sanctuaries are (1) isolation from possible invasion of unwanted fishes and (2) appropriate water quality conditions. Initially, the ultimate goal is natural recruitment, not arbitrary population goals. A magnitude of factors will determine pond productivity and population densities. Some facilities may support 20 fish/ha, others may sustain 2,000 fish/ha. Regardless of productivity, if any level of recruitment exists, it can be considered a success.

As knowledge increases so will our ability to influence the outcome of these communities. The primary focus is to provide fish the best opportunity to spawn and produce young. The best opportunity for success is to mimic the physical features deemed important for the fish at CHLP, including its size ( $<2.3 \mathrm{ha}$ ), physical attributes (i.e., depth, configuration), water quality, and the abundance and diversity of cover.

Figures 82 and 83 provide an illustration of a sanctuary based on the manmade oxbow design. Its concept is intended to accentuate the features of a natural oxbow. The design focuses on native fish needs while incorporating features that benefit other animal and plant communities.

\section{Key Features for Sanctuary Habitats}

\section{Size and Depth}

Initially, ponds should be kept to $<2.5$ ha to facilitate manageability. An exception would be for ponds that could be gravity drained. Habitats should have a maximum depth of 4 $\mathrm{m}$.

\section{Drainage}

New facilities should be built to allow for gravity drainage. This would facilitate salvage and renovation without the need for chemicals (Minckley and others, 2003). If gravity drainage is not possible, an alternative solution would be the ability to pump these ponds dry. Installing a drainage pipe in the deepest portion of the pond would assist in salvaging efforts while reducing the problems associated with chemical renovation.

\section{Aeration/Circulation}

Thermal stratification and anoxic conditions led to poor production and in severe cases, fish kills (Brouder and Jann, 2004). Dissolved oxygen (DO) should be maintained at $>3$ $\mathrm{mg} / \mathrm{L}$ when possible. Stratification can be disrupted and DO augmented by ground-water intrusion (e.g., Cibola High Levee Pond), use of a pumping well or screened water, and use of aeration systems. Figure 83 illustrates an inflow pipe aimed upwards to cause upwelling and optimal circulation.

\section{Cover}

Bonytail require dark, overhead cover in the form of large riprap, concrete culverts, or dense brush or debris piles. Small fish also use aquatic vegetation for cover and sites where they feed on invertebrates. A potential feature is a "hummock," which provides cover in addition to other positive benefits. A hummock is a submerged mound that supports emergent vegetation but is surrounded by water sufficiently deep to limit vegetation expansion (Thullen and others, 2002). These features would provide shading, cover, and conditions that benefit invertebrates and other fish food organisms.

\section{Spawning Requirement}

Spawning substrates specific for both bonytail and razorback suckers should be placed at various locations. Depths of spawning terraces would range from 0.5 to $2 \mathrm{~m}$, with some being adjacent to deep water.

\section{Orientation}

The southern shoreline should be planted with large trees (i.e., cottonwood and willow) to provide shade and root structure, which would also provide cover. The deeper portion of the pond should lie along the southern shoreline, again to provide increased shade during late afternoon. 


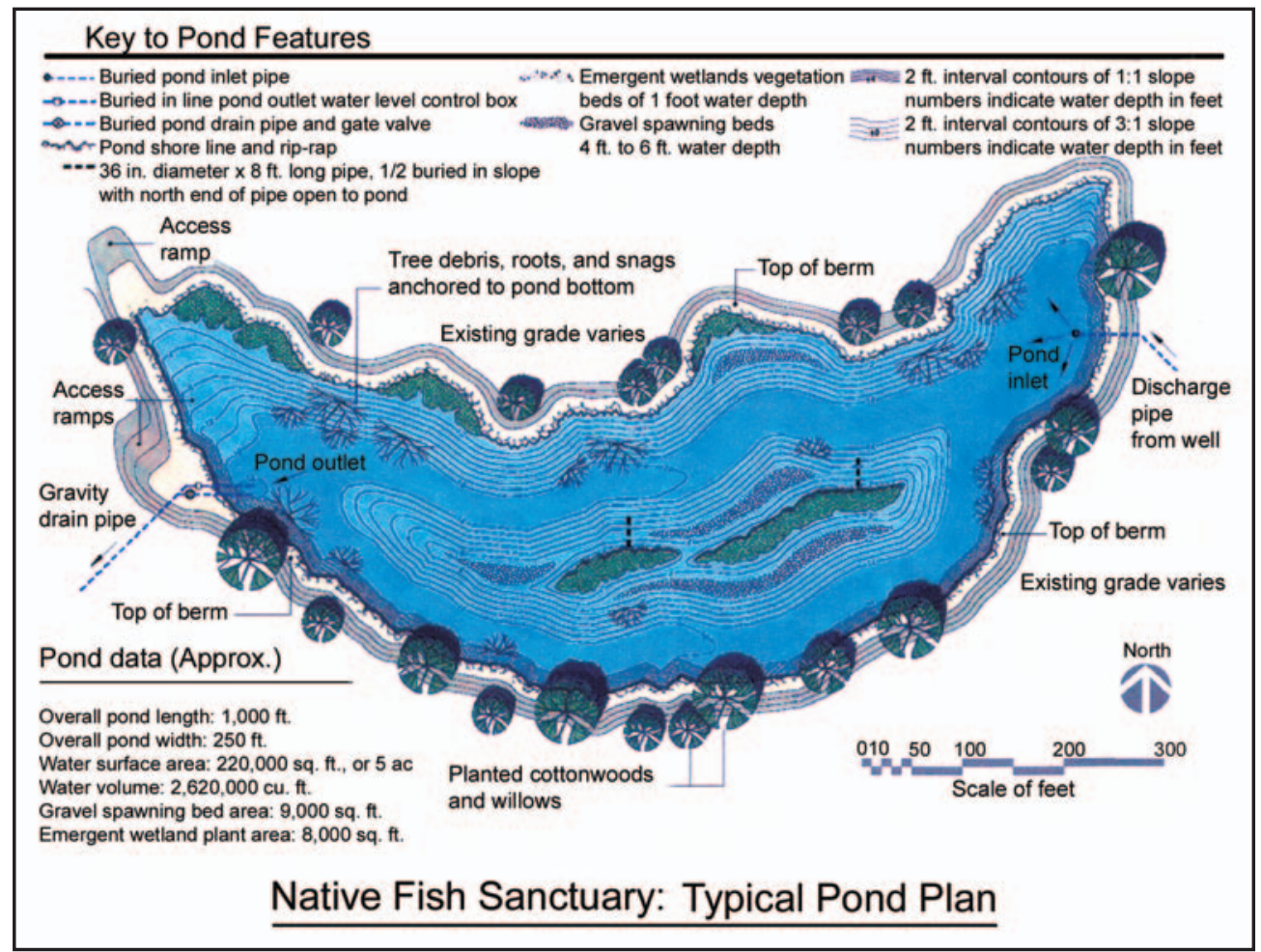

Fig. 82. Landscape illustration (surface, top down) of a native fish sanctuary designed to mimic features found at Cibola High Levee Pond and other natural oxbow habitats. The facility would contain spawning bars, vegetative and brush cover, and submergent, emergent, and riparian vegetation.

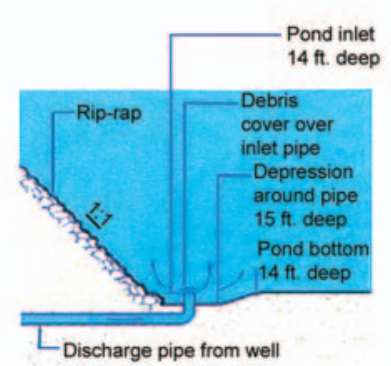

Pond Inlet Detail

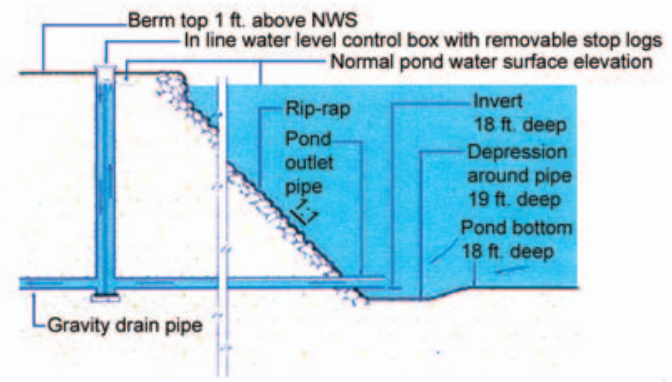

Pond Outlet Detail

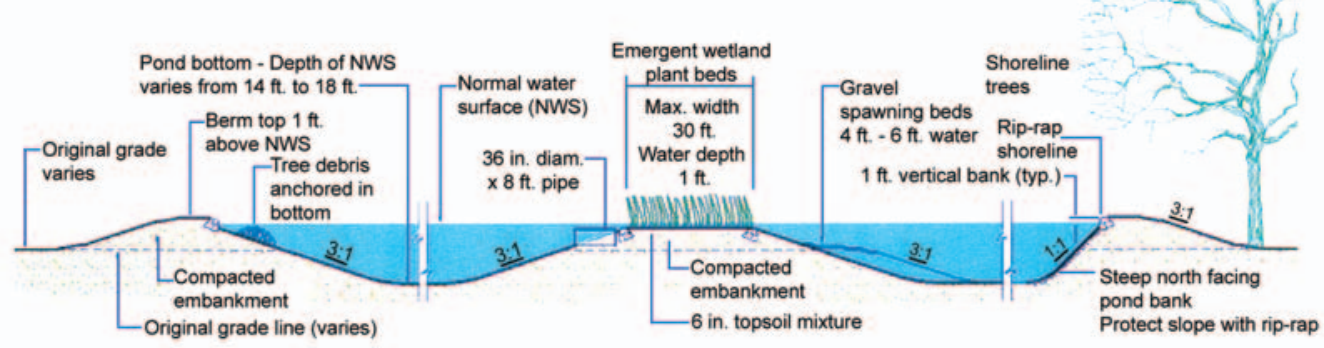

\section{Native Fish Sanctuary: Typical Pond Cross-Section}

Fig. 83. Landscape illustration (side view) of a native fish sanctuary designed to mimic features found at Cibola High Levee Pond and other natural oxbow habitats. The facility would contain a well and drain to ensure circulation and total drainage for salvage and renovation purposes. 


\section{Acknowledgments}

This study would not have been possible without the support of several key people and their staffs. Jeanette Carpenter assisted in study design and implementation. Paul Marsh, Professor at Arizona State University, and his staff led or assisted in key research elements of this study. Dennis Scarnechia mounted and analyzed scale samples. John Beavers provided zooplankton analysis. Ken Bovee developed the bathometry and substrate maps. Jon Pattie developed the landscape drawing. Tom Alexander and Mike Gold, Cibola National Wildlife Refuge managers, provided access and logistical support. Chuck Minckley, Fisheries Biologist for the USFWS Arizona Fishery Resources Office, provided expertise, field assistance, equipment, and document review. Mark Brouder, Assistant Project Leader for the USFWS Arizona Fishery Resources Office in Pinetop, provided expertise and field assistance. I thank Richard Wydoski, Harold Tyus, Paul Marsh, Chuck Minckley, and Tim Modde for their technical review and helpful comments. Jennifer Shoemaker, Juliette Wilson, Delia Story, and Dora Medellin conducted the final review, formatting, and document layout. Necessary permits were provided by the Arizona Game and Fish Department, California Department of Fish and Game, and U.S. Fish and Wildlife Service.

\section{References Cited}

Abate, P.D., Welker, T., and Holden, P.B., 2002, Razorback sucker studies on Lake Mead, Nevada and Arizona: 2000-2002 annual report: Prepared for the Department of Resources, Southern Nevada Water Authority, PR-578-6, BIO-WEST, Inc., Logan, Utah, 63 p.

Alagona, P.S., 2004, The ghosts of endangered species past: Recent lessons at the intersection of history and biology: Bioscience, v. 54, p. 984-985.

Allan, R.C., and Roden, D.L., 1978, Fish of Lake Mead and Lake Mohave: Biological Bulletin No. 7, Nevada Department of Wildlife, Reno, 105 p.

Badame, P.V., and Hudson, J.M., 2003, Reintroduction and monitoring of hatchery-reared bonytail in the Colorado and Green Rivers: 1996-2001: Upper Colorado River Endangered Fish Recovery Program Project \#26, Utah Division of Wildlife Resources, Salt Lake City, 54 p.

Baird, S.F., and Girard, C., 1853, Fishes: Report of an expedition down the Zuni and Colorado Rivers, by Captain L. Sitgreaves: U.S. Senate Executive Document 59, Thirty-third Congress, Second session, Washington, D.C., p. 148-152.
Banks, J.L., 1964, Fish species distribution in Dinosaur National Monument during 1961-1962: Master's thesis, Colorado State University, Fort Collins, 96 p.

Bestgen, K.R., 1990, Status review of the razorback sucker, Xyrauchen texanus: Contribution 44, Colorado State University Larval Fish Laboratory, Fort Collins, 92 p.

Bestgen, K.R., Haines, G.B., Brunson, R., Chart, T., Trammell, M., Muth, R.T., Birchell, G., Christopherson, K., and Bundy, J.M., 2002, Status of wild razorback sucker in the Green River Basin, Utah and Colorado, determined from basin wide monitoring and other sampling programs: Contribution 126, Colorado State University Larval Fish Laboratory, Fort Collins, 73 p., appendices.

Blake, W.P., 1864, Diary notes: Arizona Historical Society, MS 78, Box 1, from book marked "Jan 18th 1864, Castle Dome 1" vol. 63, Tucson, Arizona.

Bradford, R.H., and Gurtin, S.D., 2000, Habitat use by hatchery-reared adult razorback suckers released into the Lower Colorado River, California-Arizona: North American Journal of Fisheries Management, v. 20, p. 154-167.

Brandenburg, W.H., Farrington, M.A., and Gottlieb, S.J., 2003, Razorback sucker larval fish surveys in the San Juan River during 2002, for the San Juan River Basin Recovery Implementation Program: Museum of Southwestern Biology, University of New Mexico, Albuquerque.

Brouder, M.J., and Jann, D.B., 2004, Management of native fish protected habitats on Imperial and Havasu National Wildlife Refuges, 2002-2004: Document No: USFWSAZFRO-PA-04-016, U.S. Fish and Wildlife Service, Pinetop, Arizona, $31 \mathrm{p}$.

Brower, A., Reedy, C., and Yelin-Kefer, J., 2001, Consensus versus conservation in the Upper Colorado River Basin Recovery Implementation Program: Conservation Biology, v. 15, p. 1001-1007.

Burdick, B.D., 1994, Conceptual management plan for habitat enhancement in flooded bottomlands: Escalante State Wildlife Area, Gunnison River downstream of Delta, Colorado: Colorado River Fishery Project, U.S. Fish and Wildlife Service, Grand Junction, Colorado, 25 p.

Burdick, B.D., 2002, Evaluating the use of sloped gravel-pit ponds by listed and non-listed native fishes and removal of nonnative fishes from sloped gravel-pit ponds in the upper Colorado River near Grand Junction, Colorado: Recovery Program Report Project No. C-6-GP, Colorado River Fishery Project, U.S. Fish and Wildlife Service, Grand Junction, Colorado, 49 p., appendices. 
Burdick, B.D., 2003, Monitoring and evaluation of various sizes of domestic-reared razorback sucker stocked in the Upper Colorado and Gunnison Rivers, 1995-2001: Recovery Program Project No. 50, U.S. Fish and Wildlife Service, Colorado River Fishery Project, Grand Junction, Colorado, $54 \mathrm{p}$.

Burdick, B.D., and Bonar, R.B., 1997, Experimental stocking of adult razorback sucker in the upper Colorado and Gunnison rivers: Colorado River Fishery Project, U.S. Fish and Wildlife Service, Grand Junction, Colorado, 28 p., appendices.

Burdick, B.D., Wydoski, R.S., and McAda, C.W., 1995, Stocking plan for razorback sucker in the Upper Colorado and Gunnison Rivers: Recovery program for the endangered fishes of the Upper Colorado River: U.S. Fish and Wildlife Service, Denver, Colorado, 13 p.

Chart, T.E., and Cranney, J.S., 1993, Radio-telemetered monitoring of stocked bonytail chubs (Gila elegans) in the Green River, Utah, 1988-1989: Final report, Utah Division of Wildlife Resources, Salt Lake City, 72 p.

Christopherson, K.D., Birchell, G.J., and Modde, T., 2004, Draft report: Evaluation of larval razorback sucker and bonytail survival in the Stirrup floodplain depression with nonnative fish species: Report submitted to the Upper Colorado River Endangered Fish Recovery Program, Project No. C-6-rz/bt, Utah Division of Wildlife, Vernal, Utah, 24 p.

Clarkson, R.W., Marsh, P.C., Stefferud, J.A., and Stefferud, S.A., 2005, Conflicts between native fish and nonnative sportfish management in the southwestern United States: Fisheries, v. 30, no. 9, p. 20-27.

Creef, E.D., and Clarkson, R.W., 1993, Razorback sucker (Xyrauchen texanus) and Colorado pikeminnow (Ptychocheilus lucius) monitoring, Verde and Salt Rivers, Arizona 1991-1993: Special report: Nongame and Endangered Wildlife Program, Arizona Game and Fish Department, Phoenix, 7 p., appendices.

Crowl, T.A., Bissonette, G., Thiede, G., Alder, L., and Rivera, S., 2000, Bonytail, draft 1998 annual report: Ecology Center, Department of Fisheries and Wildlife, Utah State University, Logan, 69 p.

Czapla, T., 1998, Genetics management plan: Final report submitted to the Recovery Implementation Program for the Endangered Fish Species in the Upper Colorado Basin, U.S. Fish and Wildlife Service, Denver, Colorado, 48 p.

Dill, W.A., 1944, The fishery of the lower Colorado River: California Fish and Game, v. 30, p. 109-211.
Douglas, M.E., and Marsh, P.C., 1996, Population estimates/ population measurements of Gila cypha, an endangered cyprinid fish in the Grand Canyon region of Arizona: Copeia, no. 1, p. 15-28.

Douglas, M.E., Miller, R.R., and Minckley, W.L., 1998, Multivariate discrimination of Colorado Plateau Gila spp.: The "Art of Seeing Well" revisited: Transactions of the American Fisheries Society, v. 127, p. 163-173.

Douglas, M.R., Brunner, P.C., and Douglas, M.E., 2000, Late season reproduction by big-river Catostomidae in Grand Canyon (Arizona): Copeia, 2000, no. 1, p. 238-244.

Douglas, M.R., Brunner, P.C., and Douglas, M.E., 2003, Drought in an evolutionary context: Molecular variability in flannelmouth sucker (Catostomus latipinnis) from the Colorado River Basin of western North America: Freshwater Biology, v. 48, p. 1254-1273.

Douglas, P.A., 1952, Notes on the spawning of the humpback sucker Xyrauchen texanus (Abbott): California Fish and Game, v. 38, no. 2, p. 148-155.

Dowling, T.E., and DeMarais, B.K., 1993, Evolutionary significance of introgressive hybridization in cyprinid fishes: Nature, v. 362, p. 444-446.

Dowling, T.E., Marsh, P.C., Kelsen, A.T., and Tibbets, C.A., 2005, Genetic monitoring of wild and repatriated populations of endangered razorback sucker (Xyrauchen texanus, Catostomidae, Teleostei) in Lake Mohave, Arizona-Nevada: Molecular Ecology, v. 14, p. 123-135.

Flagg, R., 1982, Disease survey of the Colorado River fishes: Report Number 4, in Part 3, Colorado River Fishery Project, Final report, contracted studies: U.S. Fish and Wildlife Service and U.S. Bureau of Reclamation, Salt Lake City, Utah, p. 177-184.

Golden, M.E., and Holden, P.B., 2003, Determining conditions that promote razorback sucker recruitment in Lake Mead: A summary of the 2000-2003 pilot study: PR-7842, Submitted by BIO-WEST Inc., Logan, Utah, to Southern Nevada Water Authority, 47 p.

Greenwell, M.G., 2003, Shark transport: Knowns and unknowns: Twenty-eighth Annual Eastern Fish Health Workshop, April 21-23, John Shedd Aquarium, Chicago, Illinois.

Grinnell, J., 1914, An account of the mammals and birds of the lower Colorado Valley, with special reference to the distributional problems present: University of California Publications in Zoology, v. 12, p. 51-294. 
Gurtin, S.D., and Bradford, R.H., 2000, Use of habitat and associated habitat characteristics used by hatchery-reared adult razorback suckers implanted with ultra-sonic transmitters and released into the lower Imperial Division, Colorado River: Contract report No. 4, Cooperative Agreement 99FG-34-0005, Arizona Game and Fish Department, Phoenix, $74 \mathrm{p}$.

Gutermuth, F.B., Lentsch, L.D., and Bestgen, K.R., 1994, Collection of age-0 razorback sucker (Xyrauchen texanus) in the lower Green River, Utah: Southwestern Naturalist, v. 39, p. 389-391.

Hagan, H.K., and Banks, J.L., 1963, Ecological and limnological studies of the Green River in Dinosaur National Monument: National Park Service and Colorado State University, Fort Collins, $31 \mathrm{p}$.

Hawkins, L.A., Tyus, H.M., Minckley, W.L., and Schultz, D.L., 2004, Comparison of four techniques for aging adult Colorado pike minnow, Ptychocheilus lucius: Southwestern Naturalist, v. 49, p. 203-208.

Hedrick, P.W, Dowling, T.E., and Minckley, W.L., 2000, Establishing a captive broodstock for the endangered bonytail chub (Gila elegans): Journal of Heredity, v. 91, no. 1, p. 35-49.

Hendrickson, D.A., 1993, Evaluation of the razorback sucker (Xyrauchen texanus) and Colorado squawfish (Ptychocheilus lucius) reintroduction programs in central Arizona based on surveys of fish populations in the Salt and Verde Rivers from 1986-1990: Final report: Non-Game and Endangered Wildlife Program, Arizona Game and Fish Department, Phoenix, $166 \mathrm{p}$.

Holden, P.B., Abate, P.D., and Ruppert, J.B., 1997, Razorback sucker studies on Lake Mead, Nevada: 1996-1997 annual report: PR-578-1, BIO-WEST Inc., Logan, Utah.

Holden, P.B., and Stalnaker, C.B., 1970, Systematic studies of the cyprinid genus Gila in the Upper Colorado River Basin: Copeia, v. 3, p. 409-420.

Holden, P.B., and Stalnaker, C.B., 1975, Distribution and abundance of mainstream fishes of the Middle and Upper Colorado River Basins: 1967-1973: Transactions of the American Fisheries Society, v. 104, p. 217-231.

Horn, M.J., 1996, Nutritional limitation of recruitment in the razorback sucker (Xyrauchen texanus): Tempe, Arizona, Arizona State University, Ph.D. dissertation, 280 p.

Horn, M.J., Marsh, P.C., Mueller, G., and Burke, T., 1994, Predation by odonate nymphs on larval razorback sucker (Xyrauchen texanus) under laboratory conditions: The Southwestern Naturalist, v. 39, no. 4, p. 371-374.
Hubbs, C.L., and Miller, R.R., 1953, Hybridization in nature between the fish general Catostomus and Xyrauchen: Papers of the Michigan Academy of Science, Arts, and Letters, v. 38, p. 207-233.

Irving, D.B., and Burdick, B.D., 1995, Reconnaissance inventory and prioritization of existing and potential bottomlands in the Upper Colorado River Basin 1993-1994: U.S. Fish and Wildlife Service, Colorado River Fishery Project, Vernal, Utah, $57 \mathrm{p}$.

James, G.W., 1906, The wonders of the Colorado Desert, Volumes I and II: Boston, Massachusetts, Little, Brown, and Company, $487 \mathrm{p}$.

Johnson, J.E., 1985, Reintroducing the natives: Razorback sucker: Proceedings of the Desert Fishes Council, v. 13, p. 73-79.

Johnson, J.E., 1997, Predator recognition by endangered fishes: Interagency Agreement No. 2-AA-30-00170, submitted by University of Arkansas, Fayetteville, to the Bureau of Reclamation, Boulder City, Nevada, 113 p.

Jonez, A., and Sumner, R.C., 1954, Lakes Meade and Mohave investigations: A comparative study of an established reservoir as related to a newly created impoundment: Federal Aid to Fisheries Restoration Project Completion Report, F-1-R, 1-186: Nevada Fish and Game Commission, Reno, $186 \mathrm{p}$.

Jordan, D.S., 1891, Report of explorations in Utah and Colorado during the summer of 1889 with an account of the fishes found in each of the river basins examined: U.S. Fish Commerce Bulletin, v. 9, p. 1-40.

Jordan, D.S., and Evermann, B.W., 1896, The fishes of North and Middle America: Bulletin of the U.S. Natural Museum, part 1, 47:I + 1x, p. 1-1240.

Kaeding, L.R., Burdick, B.D., Schrader, P.A., and Noonan, W.R., 1986, Recent capture of a bonytail (Gila elegans) and observations on this nearly extinct cyprinid from the Colorado River: Copeia, v. 4, p. 1021-1023.

Karp, C.A., and Mueller, G., 2002, Razorback sucker movements and habitat use in the San Juan River inflow, Lake Powell, Utah, 1995-1997: Western North American Naturalist, v. 62, no. 1, p. 106-111.

Kennedy, D.M., 1979, Ecological investigations of backwaters along the Lower Colorado River: Tuscon, Arizona, University of Arizona, Ph.D. dissertation, 219 p.

Kolb, E.L., 1927, Through the Grand Canyon from Wyoming to Mexico: New York, The Macmillan Company, 332 p. 
LaBarbara, M., 1999, Report on native fish grow-out facilities at Cibola and Imperial National Wildlife Refuges: 1993-1995. U.S. Fish and Wildlife Service, Arizona Fishery Resources Office, Parker, Arizona.

La Rivers, I., 1962, Fishes and fisheries of Nevada: Nevada State Fish and Game Commission, Carson City, 782 p.

Langhorst, D.R., and Marsh, P.C., 1986, Early life history of razorback sucker in Lake Mohave: Final report, U.S. Bureau of Reclamation, Contract 5-PG-30-06440, Boulder City, Nevada, 36 p.

Lanigan, S.H., and Tyus, H.M., 1989, Population size and status of razorback sucker in the Green River basin, Utah and Colorado: North American Journal of Fisheries Management, v. 9, p. 68-73.

Lenon, N., Stave, K., Burke, T., and Deacon, J.E., 2002, Bonytail (Gila elegans) may enhance survival of razorback sucker (Xyrauchen texanus) in rearing ponds by preying on exotic crayfish: Journal of the Arizona-Nevada Academy of Sciences, v. 34, no. 1, p. 46-52.

Lentsch, L.D., Muth, R.T., Thompson, P.D., Hoskins, B.G., and Crowl, T.A., 1996, Options for selective control of nonnative fishes in the Upper Colorado River Basin: Publication No. 96-14, Utah Division of Wildlife Resources, Salt Lake City, 173 p.

Lovich, J.E., Garstka, W.R., Cooper, Jr., W.E., 1990, Female participation in courtship behavior of the turtle Trachemys $s$. scripta: Journal of Herpetology, v. 24, no. 4, p. 422-424.

Maddux, H.R., Fitzpatrick, L.A., and Noonon, W.R., 1993, Colorado River endangered fishes critical habitat: U.S. Fish and Wildlife Service, Salt Lake City, Utah, 225 p.

Marsh, P.C., 1985, Effect of incubation temperature on survival of embryos of native Colorado River fishes: The Southwestern Naturalist, v. 30, p. 129-140.

Marsh, P.C., 1987a, Digestive tract contents of adult razorback suckers in Lake Mohave, Arizona-Nevada: Transactions of the American Fisheries Society, v. 116, p. 117-119.

Marsh, P.C., 1987b, Native fishes at Buenos Aires National Wildlife Refuge and Arizona State University Research Park, Arizona: Opportunities for management, research, and public education on endangered species: Proceedings of the Nineteenth annual symposium Desert Fishes Council.

Marsh, P.C., 1997a, Age estimation from otoliths of bonytail chub Gila elegans from Lake Mohave, Arizona and Nevada: Order \# 22340-5-0033 to U.S. Fish and Wildlife Service 24 February 1997, Arizona Fishery Resources Office, Parker, Arizona.
Marsh, P.C., 1997b, Subject: Stocking records for bonytail: Memorandum dated 28 January 1997 to Tom Burke, U.S. Bureau of Reclamation, Boulder City, Nevada: Arizona State University, Center for Environmental Studies, Tempe.

Marsh, P.C., 2000, Fish population status and evaluation in the Cibola High Levee Pond: Contract 99-FG-30-00051, Report to the U.S. Bureau of Reclamation, Boulder City, Nevada, Arizona State University, Tempe.

Marsh, P.C., 2004a, Fishery management conflicts in the southwestern United States: Keynote address, 29 February 2004, Annual meeting of the Western Division of the American Fisheries Society, Salt Lake City, Utah.

Marsh, P.C., 2004b, Spatial and temporal aspects of bonytail chub movement and habitat use, Cibola High Levee Pond, Lower Colorado River, Arizona and California, 2003-2004: submitted to U.S. Geological Survey, Denver, Colorado, and Arizona State University, Tempe, 15 p.

Marsh, P.C., and Brooks, J.E., 1989, Predation by icatlurid catfishes as a deterrent to reestablishment of hatchery-reared razorback suckers: The Southwestern Naturalist, v. 34, no. 2, p. 188-195.

Marsh, P.C., and Kesner, B.R., 2000, Movements of sub-adult razorback sucker in a regulated reach and a reservoir of the Lower Colorado River: submitted by Arizona State University, Tempe, to U.S. Geological Survey, Contract 14450009-94-1108.

Marsh, P.C., Kesner B.R., and Pacey, C.A., 2005, Repatriation as a management strategy to conserve a critically imperiled fish species: North American Journal of Fisheries Management, v. 25, p. 547-556.

Marsh, P.C., and Langhorst, D.R., 1988, Feeding and fate of wild larval razorback suckers: Environmental Biology of Fishes, v. 1, p. 59-67.

Marsh, P.C., and Minckley, W.L., 1989, Observations on recruitment and ecology of razorback sucker: Lower Colorado River, Arizona-California-Nevada: Great Basin Naturalist, v. 49, p. 71-78.

Marsh, P.C., and Mueller, G.A., 1999, Spring-summer movements of bonytails in a Colorado River Reservoir, Lake Mohave, Arizona and Nevada: U.S. Geological Survey Open File Report 99-103, 41 p.

Marsh, P.C., Pacey, C.A., and Kesner, B.R., 2003, Decline of the razorback sucker in Lake Mohave, Colorado River, Arizona and Nevada: Transactions of the American Fisheries Society, v. 132, p. 1251-1256. 
Marsh, P.C., and Papoulias, D., 1989, Ichthyoplankton of Lake Havasu, a Colorado River impoundment: California Fish and Game, v. 75 , no. 2, p. 68-73.

Marsh, P.C., and Schooley, J.D., 2004, Bonytail chub foods and feeding habits, Cibola High Levee Pond, Lower Colorado River, Arizona and California, 2003-2004: submitted to U.S. Geological Survey, Denver, Colorado, and School of Life Sciences, Arizona State University, Tempe, 8 p.

Marshall, C.W., 1976, Inventory of fish species and aquatic environments of fifteen backwaters of the Topock Gorge Division of the Colorado River: Inland Fisheries Administrative Report 76-4, California Department of Fish and Game, Sacramento, 98 p.

McAda, C.W., 2003, Flow recommendations to benefit endangered fishes in the Colorado and Gunnison Rivers: Recovery Program Project No. 54, U.S. Fish and Wildlife Service, Grand Junction, Colorado, 198 p.

McAda, C.W., and Wydoski, R.S., 1980, The razorback sucker, Xyrauchen texanus, in the Upper Colorado River Basin, 1974-1976: U.S. Fish and Wildlife Service Technical Paper 99, Denver, Colorado, 15 p.

McCarthy, M.S., and Minckley, W.L., 1987, Age estimation for razorback sucker (Pisces: Catostomidae) from Lake Mohave, Arizona-Nevada: Journal of the Arizona-Nevada Academy of Sciences, v. 21, p. 87-97.

McDonald, D.B., and Dotson, P.A., 1960, Pre-impoundment investigations of the Green River and Colorado River developments: Job No. V, Department Information Bulletin No. 60-3, Utah Department of Fish and Game, Salt Lake City, 70 p.

McKinney, T., Persons, W.R., and Rogers, R.S., 1999, Ecology of flannelmouth sucker in the Lee's Ferry tailwater, Colorado River, Arizona: Great Basin Naturalist, v. 59, p. 259-267.

Meyers, L.L., 1992, Reintroduction of bonytail chubs Gila elegans into the Green River, Utah (abstract): Proceedings of the Desert Fishes Council, v. XXIV, p. 31.

Miller, R.R., 1946, Gila cypha, a remarkable new species of cyprinid fish from the Colorado River in Grand Canyon, Arizona: Journal of the Washington Academy of Sciences, v. 36, p. 409-415.

Miller, R.R., 1961, Man and the changing fish fauna of the American Southwest: Papers of the Michigan Academy of Science, Arts, and Letters, v. 46, p. 365-404.

Miller, R.R., Williams, J.D., and Williams, J.E., 1989, Extinctions of North American fishes during the past century: Fisheries, v. 14, no. 6, p. 22-38.
Minckley, C.O., and Thorson, M., 2002, Interim report for bonytail broodstock collections from Lake Mohave, AZ-NV: U.S. Fish and Wildlife Service, Arizona Fishery Resources Office, Parker, 16 p.

Minckley, C.O., and Thorson, M., 2003, Bonytail broodstock collection report, Lake Mohave AZ-NV: Project No. 20000304-006, U.S. Fish and Wildlife Service AZFRO-PA-03001, Arizona Fishery Resources Office, Parker, 14 p.

Minckley, C.O., and Thorson, M., 2004, Bonytail broodstock collection report, Lake Mohave AZ-NV: Project No. 20000304-006, U.S. Fish and Wildlife Service AZFRO-PA-040017, Arizona Fishery Resources Office, Parker, 14 p.

Minckley, W.L., 1973, Fishes of Arizona: Arizona Game and Fish Department, Phoenix, 293 p.

Minckley, W.L., 1979, Aquatic habitats and fishes of the Lower Colorado River: Bureau of Reclamation contract No. 14-06-300-2529, Arizona State University, Tempe, 478 p.

Minckley, W.L., 1983, Status of the razorback sucker, Xyrauchen texanus (Abbott), in the Lower Colorado River Basin: The Southwestern Naturalist, v. 28, no. 2, p. 165187.

Minckley, W.L., 1985, Native fishes and natural aquatic habitats in U.S. Fish and Wildlife Service Region II, west of the Continental Divide: U.S. Department of the Interior, Fish and Wildlife Service, Division of Endangered Species, Albuquerque, New Mexico, 158 p.

Minckley, W.L., Buth, D.G., Mayden, R.L., 1989, Origin of broodstock and allozyme variation in hatchery-reared bonytail, an endangered North American Cyprinid Fish: Transactions of the American Fisheries Society, v. 118, p. 131-137.

Minckley, W.L., and Deacon, J.E., eds., 1991, Battle against extinction: Native fish management in the American West: Tucson and London, The University of Arizona Press, 517 p.

Minckley, W.L., Marsh, P.C., Brooks, J.E., Johnson, J.E., and Jensen, B.L., 1991, Management toward recovery of the razorback sucker, in Minckley, W.L., and Deacon, J.E., eds., Battle against extinction: Native fish management in the American West: Tuscon and London, The University of Arizona Press, p. 303-378.

Minckley, W.L., Marsh, P.C., Deacon, J.E., Dowling, T.E., Hedrick, P.W., Matthews, W.J., and Mueller, G., 2003, A conservation plan for native fishes of the Lower Colorado River: BioScience, v. 53, no. 3, p. 219-234.

Modde, T., 1996, Juvenile razorback sucker (Xyrauchen texanus) in a managed wetland adjacent to the Green River: Great Basin Naturalist, v. 56, no. 4, p. 375-376. 
Modde, T., 2005, Can habitat mitigate the impacts of nonnative species on rare fishes? Observations from the Upper Colorado River Basin, in Brouder, M.J., Springer, C.L., and Leon, S.C., eds., Proceedings from two symposia: Restoring native fish to the Lower Colorado River: Interactions of the native and nonnative fishes, July 13-14, 1999, Las Vegas, Nevada, and Restoring natural function within a modified riverine environment: The Lower Colorado River, July 8-9, 1998, Las Vegas, Nevada: U.S. Fish and Wildlife Service, Southwest Region, Albuquerque, New Mexico, p. 123-128.

Modde, T., Burnham, K.P., and Wick, E.J., 1996, Population status of the razorback sucker in the Middle Green River (U.S.A.): Conservation Biology, v. 10, no. 1, p. 110-119.

Modde, T., and Fuller, M., 2002, Feasibility of channel catfish reduction in the lower Yampa River: Project No. 88, Colorado River Fishery Project, U.S. Fish and Wildlife Service, Vernal, Utah, 32 p.

Modde, T., and Haines, G.B., 2005, Survival and growth of stocked razorback sucker and bonytail in multiple floodplain wetlands of the Middle Green River under reset conditions: Final report C-6-bt/rz, submitted to the Recovery Implementation Program for the Endangered Fish Species in the Upper Colorado River Basin, U.S. Fish and Wildlife Service, Denver, Colorado, 66 p.

Modde, T., and Irving, D.B., 1998, Use of multiple spawning sites and seasonal movement by razorback suckers in the Middle Green River, Utah: North American Journal of Fisheries Management, v. 18, p. 318-326.

Moffett, J.W., 1943, A preliminary report of the fishery of Lake Mead: Transactions of the Eight North American Wildlife Conference, p. 179-186.

Moyle, P.B., and Sato, G.M., 1991, On the design of preserves to protect native fishes, in Minckley, W.L., and Deacon, J.E., eds., Battle against extinction: Native fish management in the American West: Tucson and London, University of Arizona Press, p. 155-170.

Mueller, G.A., 1984, Spawning by Rhinichthys osculus (Cyprinidae), in the San Francisco River, New Mexico: The Southwestern Naturalist, v. 29, p. 354-356.

Mueller, G., 1989, Observations of spawning razorback suckers (Xyrauchen texanus) utilizing riverine habitat in the Lower Colorado River, Arizona-Nevada: The Southwestern Naturalist, v. 34, no. 1, p. 147-149.

Mueller, G., 1990, Fishery investigations, Central Arizona Project canal system: Final Report 1986-1989, Bureau of Reclamation, Boulder City, Nevada, 114 p.

Mueller, G., 1995, A program for maintaining the razorback sucker in Lake Mohave: American Fisheries Society Symposium, v. 15, p. 127-135.
Mueller, G., 2003, The role of stocking in the reestablishment and augmentation of native fish in the Lower Colorado River mainstem (1998-2002): U.S. Geological Survey Open File Report 03-288, 42 p.

Mueller, G.A., 2005, Predatory fish removal and native fish recovery in the Colorado River mainstem: What have we learned?: Fisheries Magazine, v. 30, no. 9, p. 10-19

Mueller, G.A., and Brooks, J.L., 2004, Collection of an adult gizzard shad (Dorosoma cepedianum) from the San Juan River, Utah: Western North American Naturalist, v. 64, no. 1, p. 135-136.

Mueller, G.A., Carpenter, J., Marsh, P.C., and Minckley, C.O., 2003a, Cibola High Levee Pond, annual report 2003: U.S. Geological Survey, Denver, Colorado, http://www.fort.usgs. gov/products/publications/21201/21201.asp

Mueller, G.A., Carpenter, J., and Marsh, P.C., 2005, Cibola High Levee Pond, annual report 2004: U.S. Geological Survey Open-File Report 2005-1075, 46 p.

Mueller, G.A., Carpenter, J., and Minckley, C.O., 2002, Cibola High Levee Pond, annual report 2002: U.S. Geological Survey, Denver, Colorado, 18 p.

Mueller, G., and Foster, D., 1999, Movement patterns, behavior, and habitat use of razorback sucker stocked into the Green River at Canyonlands National Park, Utah: U.S. Geological Survey Open-File Report 99-107, 47 p.

Mueller, G., Horn, M., Bradwish, Q., and Boobar, L., 2001, Examination of native fish recruitment and description of the fish communities found in the San Juan and Colorado River interface zones of Lake Powell: U.S. Geological Survey Open File Report 01-159, 34 p.

Mueller, G., Horn, M., Kahl, Jr., J., Burke, T., and Marsh, P., 1993, Use of larval light traps to capture razorback sucker (Xyrauchen texanus) in Lake Mohave, Arizona-Nevada: The Southwestern Naturalist, v. 38, p. 399-402.

Mueller, G. and Marsh, P.C., 1993, Assessment of the effectiveness of the barrier net and summary of scuba studies, February 1992 to June 1993: Bureau of Reclamation, Summary report to the Native Fish Work Group, Boulder City, Nevada, 12 p.

Mueller, G., and Marsh, P.C., 1995, Bonytail and razorback sucker in the Colorado River Basin, in LaRoe, E.T., Farris, G.S., Puckett, C.E., Doran, P.D., and Mac, M.J., eds., Our living resources: A report to the Nation on the distribution, abundance, and health of U.S. plants, animals, and ecosystems: U.S. Department of the Interior, National Biological Service, Washington, D.C., p. 324-326.

Mueller, G., and Marsh, P.C., 1998, Post-stocking dispersal, habitat use, and behavioral acclimation of juvenile razorback suckers (Xyrauchen texanus) in two Colorado River 
reservoirs: U.S. Geological Survey Open-File Report 98301, 24 p.

Mueller, G.A., and Marsh, P.C., 2002, Lost, a desert river and its native fishes: A historical perspective of the Lower Colorado River: U.S. Geological Survey Information and Technology Report USGS/BRD/ITR--2002--0010, 69 p.

Mueller, G.A., Marsh, P.C., Foster, D., Ulibarri, M., and Burke, T., 2003b, Factors influencing poststocking dispersal of razorback sucker: North American Journal of Fisheries Management, v. 23, p. 270-275.

Mueller, G., Marsh, P.C., Knowles, G., and Wolters, T., 2000, Distribution, movements, and habitat use of razorback sucker (Xyrauchen texanus) in a lower Colorado River reservoir, Arizona-Nevada: Western North American Naturalist, v. 60, p. 180-187.

Mueller, G., and Wick, E., 1998, Testing of golf course ponds at Page, Arizona, for suitability as grow-out facility for razorback sucker using surplus fish from Ouray National Fish Hatchery: U.S. Geological Survey Open File Report 98-151, 28 p.

Mueller, G.A., and Wydoski, R., 2004, Reintroduction of the flannelmouth sucker in the Lower Colorado River: North American Journal of Fisheries Management, v. 24, no. 1, p. 41-46.

Muth, R.T., 1995, Conceptual framework document for development of a standardized monitoring program for basin-wide evaluation of restoration activities for razorback sucker in the Green and Upper Colorado River systems: Final report of Colorado State University Larval Fish Laboratory to Upper Colorado River Endangered Fish Recovery Program, Denver, Colorado.

Muth, R.T., Haines, G.B., Meismer, S.M., Wick, E.J., Chart, T.E., Snyder, D.E., and Bundy, J.M., 1998, Reproduction and early life history of razorback sucker in the Green River, Utah and Colorado, 1992-1996: Project 34, submitted to the Recovery Implementation Program for the Endangered Fish Species in the Upper Colorado River Basin, Denver, Colorado.

Muth, R.T., and Haynes, C.M., 1984, Plexiglas light-trap for collecting small fishes in low-velocity riverine habitats: Progressive Fish-Culturist, v. 46, p. 59-62.

Muth, R.T., and Ruppert, J.B., 1996, Effects of two electrofishing currents on captive ripe razorback suckers and subsequent egg-hatching success: North American Journal of Fisheries Management, v. 16, p. 473-476.

Muth, R.T., and Ruppert, J.B., 1997, Effects of electrofishing fields on captive embryos and larvae of razorback sucker: North American Journal of Fisheries Management, v. 17, p. $160-166$.
Muth, R.T., and Wick, E.J., 1997, Field studies on larval razorback suckers in Canyonlands National Park and Glen Canyon National Recreation Area, spring 1995 and 1996: Larval Fish Laboratory, Department of Fishery and Wildlife Biology, Colorado State University, Fort Collins.

Odens, P.R., 1989, Southwest corner: The Plain Speaker, Jacumba, California.

Osmundson, D.B., 2003, Removal of nonnative centrarchids from Upper Colorado River backwaters, 1999-2001: Summary of results: Recovery Implementation Program Project No. 89, Colorado River Fishery Project, U.S. Fish and Wildlife Service, Grand Junction, Colorado, 35 p.

Osmundson, D.B., and Kaeding, L.R., 1989, Colorado squawfish and razorback sucker grow-out pond studies as part of conservation measures for the Green Mountain and Ruedi Reservoir water sales: Final report: Agreement No. 6-AA60-00150, U.S. Fish and Wildlife Service, Grand Junction, Colorado, 85 p.

Pacey, C.A., and Marsh, P.C., 1998, Resource use by native and nonnative fishes of the Lower Colorado River: Literature review, summary, and assessment of relative roles of biotic and abiotic factors in management of an imperiled indigenous ichthyofauna: Submitted by Arizona State University, Tempe, to Bureau of Reclamation, Agreement No. 7-MT-30-R0012.

Pacey, C.A., and Marsh, P.C., 2001 and 2005 (revised), Bibliography for the big river fishes of Colorado River: U.S. Geological Survey, Cooperative Agreement No. 00CRAG0004, Arizona State University, Tempe. http://www.fort.usgs.gov/products/publications/co-fishbib/ co_fishbib.asp.

Pattie, J.O., 1833, The personal narrative of James Ohio Pattie of Kentucky: Published by T. Flint, Ohio District, Ohio Historical Society, Archives/Library, call number 917.8, P277p, 300 p.

Paukert, C.P., Ward, D.L., Ward, Sponholtz, P.J., and Hilwig, K.D., 2005, Effects of repeated hoopnetting and handling of bonytail chub. Journal of Freshwater Ecology v. 20, no. 4, p. 649-654.

Pimental, R., and Bulkley, R.V., 1983, Concentrations of total dissolved solids preferred or avoided by endangered Colorado River fishes (Ptychocheilus lucius, Gila cypha, G. elegans): Transactions of the American Fisheries Society, v. 112 , no. 5 , p. 595-600.

Portz, D.E., and Tyus, H.M., 2004, Fish humps in two Colorado River fishes: a morphological response to cyprinid predation?: Environmental Biology of Fishes, v. 71, p. 233-245. 
Rinne, J.N., Johnson, J.E., Jensen, B.L., Ruger, A.W., and Sourenson, R., 1986, The role of hatcheries in the management and recovery of threatened and endangered fishes, in Stroud, R.H., ed., Fish culture in fisheries management: Bethesda, Maryland, American Fisheries Society, p. 271285.

Rinne, J.N., and Turner, P.R., 1991, Reclamation and alteration as management techniques, and a review of methodology in stream renovation, in Minckley, W.L., and Deacon, J.E., eds., Battle against extinction: Native fish management in the American West: Tucson and London, University of Arizona Press, p. 219-246.

Ruppert, J.B., and Muth, R.T., 1997, Effects of electrofishing fields on captive juveniles of two endangered Cyprinids: North American Journal of Fisheries Management, v. 17, p. 314-320.

Ryden, D.W., 1997, Five-year augmentation plan for razorback sucker in the San Juan River, Utah: U.S. Fish and Wildlife Service, Colorado River Fishery Project, Grand Junction, Colorado, 41 p.

Ryden, D.W., 2003a, Augmentation and monitoring of the San Juan River razorback sucker population: 2002-2003 interim progress report: Colorado River Fishery Project, U.S. Fish and Wildlife Service, Grand Junction, Colorado, 54 p.

Ryden, D.W., 2003b, Long-term monitoring of sub-adult and adult large-bodied fishes in the San Juan River: 2003 interim progress report: Colorado River Fishery Project, U.S. Fish and Wildlife Service, Grand Junction, Colorado, 67 p., appendices.

Schaefer, J., 1986, Late prehistoric adaptations during the final recessions of Lake Cahuilla: Fish camps and quarries on West Mesa, Imperial County, California: Prepared for Bureau of Land Management, Contract No. CA950-CT508: Mooney-Levine and Associates, San Diego, California, $118 \mathrm{p}$.

Scheeler, P.D., 2002, Implications of floodplain isolation and connectivity on the conservation of an endangered minnow, Oregon Chub, in the Willamette River, Oregon: Transactions of the American Fisheries Society, v. 131, p. 10701080 .

Schlosser, I.J., and Kallemeyn, L.W., 2000, Spatial variation in fish assemblages across a beaver-influenced successional landscape: Ecology, v. 81, no. 5, p. 1371-1382.

Schooley, J.D., and Thornbrugh, D.J., 2004, Survival of razorback sucker stocked into the Lower Colorado River: report by Marsh, P., Arizona State University, for Agreement No. 02FG300043, submitted to the Bureau of Reclamation, Boulder City, Nevada, 11 p.
Smith, D.M., 1992, Predator avoidance behavior in larval fishes: Abstract, proceedings of the Desert Fishes Council, v. XXIV, p. 60-61.

Smith, G.R., Miller, R.R., and Sable, W.D., 1979, Species relationships among fishes of the genus Gila in the Upper Colorado River drainage, in Linn, R.M., ed., Proceedings of the First Conference on Scientific Research in National Parks, Washington, D.C.: National Park Service Transactions and Proceedings, Series 5, p. 613-623.

Snodgrass, J.W., and Meffe, G.K., 1998, Influence of beavers on stream fish assemblages: Effects of pond age and watershed position: Ecology, v. 79, no. 3, p. 928-942.

Snyder, D.E., 1981, Contributions to a guide to the cyriniform fish larvae of the Upper Colorado River system in Colorado: Bureau of Land Management Biological Science Series 3, Denver, Colorado.

Snyder, D.E., 2003, Electrofishing and its harmful effects on fish: U.S. Geological Survey Information and Technology Report USGS/BRD/ITR--2003-0002, 149 p.

Snyder, D.E., and Meismer, S.M., 1997, Effectiveness of light traps for capture and retention of larval and early juvenile Xyrauchen texanus and larval Ptychocheilus lucius and Gila elegans: Larval Fish Laboratory, Colorado State University, Fort Collins.

Snyder, D.E., and Muth, R.T., 1990, Descriptions and identification of razorback, flannelmouth, white, Utah, bluehead, and mountain sucker larvae and early juveniles: Technical Publication 38, Colorado Division of Wildlife, Fort Collins, $152 \mathrm{p}$.

Snyder, D.E., Muth, R.T., and Bjork, C.L., 2004, Catostomid fish larvae and early juveniles of the Upper Colorado River basin: Morphological descriptions, comparisons, and computer-interactive key: Technical Publication No. 42, Colorado Division of Wildlife, Fort Collins, 110 p.

Spence, M.L., and Jackson, D., eds., 1973, The expeditions of John Charles Fremont, Volume 2: The Bear Flag revolt and the court-martial: Urbana, Chicago, and London, University of Illinois Press.

Stanford, J.A., 1994, Instream flow to assist the recovery of endangered fishes of the Upper Colorado River basin: Biological Report 24, National Biological Survey, Washington, D.C., 47 p.

Stanford, J.A., and Ward, J.V., 1986, The Colorado River system, in Davies, B.R., and Walker, K.F., eds., Ecology of River Systems: Dordrecht, The Netherlands, Dr. W. Juck Publishers, p. 353-374.

Stewart, K.M., 1957, Mohave fishing: Southwestern Museum, Highland Park, Los Angeles, Calif., v. XXXI(6), p. 198203. 
Thullen, J.S., Sartoris, J.J., and Walton, W.E., 2002, Effects of vegetation management in constructed wetland treatment cells on water quality and mosquito production: Ecological Engineering, v. 18, p. 441-457.

Toney, D.P., 1974, Observations on the propagation and rearing of two endangered fish species in a hatchery environment: Proceedings of the annual conference of the Western Association of Fish and Game Commissioners, v. 54, p. 252-259.

Tyus, H.M., 1987, Distribution, reproduction, and habitat use of the razorback sucker in the Green River, Utah, 1979-1986: Transactions of the American Fisheries Society, v. 116, p. 111-116.

Tyus, H.M., and Karp, C.A., 1989, Habitat use and streamflow needs of rare and endangered fishes, Yampa River, Colorado: Biological Report 89(14):1-27, Colorado River Fishery Project, U.S. Fish and Wildlife Service, Vernal, Utah.

Tyus, H.M., and Karp, C.A., 1990, Spawning and movements of razorback sucker, Xyrauchen texanus, in the Green River basin of Colorado and Utah: The Southwestern Naturalist, v. 35 , no. 4 , p. 427-433.

Tyus, H.M., and Saunders, III, J.F., 2000, Nonnative fish control and endangered fish recovery: Fisheries, v. 25, no. 9, p. 17-24.

Tyus, H.M., Starnes, W.C., Karp, C.A., and Saunders, III, J.F., 1999, Effects of invasive tissue collection on rainbow trout, razorback sucker, and bonytail chub: North American Journal of Fisheries Management, v. 19, p. 848-855.

Ulmer, L.C., and Anderson, K.R., 1985, Management plan for the razorback sucker (Xyrauchen texanus) in California: Information Bulletin 0013-10-1985, California Department of Fish and Game, Region 5, Blyth.

U.S. Fish and Wildlife Service, 1984, Bonytail chub (Gila elegans) recovery plan: U.S. Fish and Wildlife Service, Region 6, Denver, Colorado, 70 p.

U.S. Fish and Wildlife Service, 1993, Biological opinion on the proposed action of the Lake Havasu Fisheries Improvement Partnership Program: U.S. Fish and Wildlife Service, Region 2, Albuquerque, New Mexico.

U.S. Fish and Wildlife Service, 1997, Biological and conference opinion on Lower Colorado River operation and maintenance, Lake Mead to southerly International Boundary: U.S. Fish and Wildlife Service, Region 2, Albuquerque, New Mexico, 196 p.

U.S. Fish and Wildlife Service, 1998a, Razorback sucker (Xyrauchen texanus) recovery plan: U.S. Fish and Wildlife Service, Region 6, Denver, Colorado, 77 p.
U.S. Fish and Wildlife Service, 1998b, Bonytail study plan for biological investigations 1998: Dexter National Fish Hatchery and Technology Center, Dexter, New Mexico, 5 p.

U.S. Fish and Wildlife Service, 2002a, Bonytail (Gila elegans) recovery goals: Amendment and supplement to the Bonytail Chub Recovery Plan: U.S. Fish and Wildlife Service, Region 6, Denver, Colorado, 70 p., appendices.

U.S. Fish and Wildlife Service, 2002b, Razorback sucker (Xyrauchen texanus) recovery goals: Amendment and supplement to the Razorback Sucker Recovery Plan: U.S. Fish and Wildlife Service, Region 6, Denver, Colorado, 78 p.

U.S. Fish and Wildlife Service, 2004, Management plan for the big-river fishes of the Lower Colorado River Basin: amendment and supplement to the bonytail, humpback chub, Colorado pikeminnow, and razorback sucker recovery plans: U.S. Fish and Wildlife Service, Region 2, Albuquerque, New Mexico, 52 p.

Valdez, R.A., 1990, The endangered fish of Cataract Canyon: Final report of BIO-WEST, Inc., Logan, Utah, to U.S. Bureau of Reclamation, Salt Lake City, Utah, 94 p., appendices.

Valdez, R.A., and Clemmer, G.H., 1982, Life history and prospects for recovery of the humpback and bonytail chub, in Miller, W.H., Tyus, H.M., Carlson, C.A., eds., Fishes of the Upper Colorado River system: Present and future, western division: Bethesda, Maryland, American Fisheries Society, p. 109-119.

Valdez, R.A., Mangan, P.G., Smith, R., and Nilson, B., 1982, Upper Colorado River fisheries investigations (Rifle, Colorado to Lake Powell, Utah), in Miller, W.H., Valentine, J.J., Archer, D.L., Tyus, H.M., Valdez, R.A., and Kaeding, L., eds., Colorado River Fishery Project, Part 2: Field investigations: U.S. Bureau of Reclamation, Salt Lake City, Utah, p. 100-279.

Valdez, R.A., and Masslich, W.J., 1989, Winter habitat study of endangered fish - Green River: BIO-WEST Report No. 136-2, submitted to Bureau of Reclamation, Salt Lake City, Utah (Contract No. 6-CS-40-04490), BIO-WEST, Inc., Logan, Utah, 184 p.

Valdez, R.A., Moretti, M., and Ryel, R.J., 1994, Records of bonytail captures in the upper Colorado River Basin, Unpublished report: Utah Division of Wildlife Resources, Salt Lake City.

Valdez, R.A., and Ryel, R.J., 1997, Life history and ecology of the humpback chub in the Colorado River in Grand Canyon, Arizona, in van Riper, III, C., and Deshler, E.T., eds., Proceedings of the Third Biennial Conference of Research on the Colorado Plateau: National Park Service Transactions and Proceedings Series 97/12, p. 3-31. 
Valdez, R.A., and Wick, E.J., 1983, Natural vs. manmade backwaters as native fish habitat, in Adams, V., and Lamarra, V., eds., Aquatic resources management of the Colorado River ecosystem: Ann Arbor Science Conference, Ann Arbor, Michigan, p. 519-536.

Vanicek, C.D., 1967, Ecological studies of native Green River fishes below Flaming Gorge Dam, 1964-1966: Logan, Utah, Utah State University, Logan, Ph.D. dissertation, $125 \mathrm{p}$.

Vanicek, C.D., 1970, Distribution of Green River fishes in Utah and Colorado following the closure of Flaming Gorge Dam: The Southwestern Naturalist, v. 14, no. 3, p. 297-315.

Vanicek, C.D., and Kramer, R.H., 1969, Life history of the Colorado squawfish, Ptychocheilus lucius, and the Gila chub, Gila robusta, in the Green River in Dinosaur National Monument, 1964-1966: Transactions of the American Fisheries Society, v. 98, no. 2, p. 193-208.

Wallace, W.J., 1955, Mohave fishing equipment and methods: Anthropological Quarterly, Washington Catholic University of America Press, v. 3, p. 887-894.

Waters, M.R., 1981, Holocene lacustrine chronology and archaeology of ancient Lake Cahuilla, California: Department of Geosciences, University of Arizona, Tucson.

Wilke, P.J., 1980, Prehistoric weir fishing on recessional shorelines of Lake Cahuilla, Salton Basin, southeastern California: Proceedings of the Desert Fishes Council, v. 11, p. 101-102.
Williams, E.S., and Thorne, E.T., 1996, Exertional myopathy (capture myopathy), in Fairbrother, A., Locke, L.N., and Hoff, G.L., eds., Non-infectious diseases of wildlife: Ames, Iowa State University Press, p. 181-193.

Williams, J.E., 1991, Preserves and refuges for native western fishes: History and management, in Minckley, W.L., and Deacon, J.E., eds., Battle against extinction: Native fish management in the American West: Tucson and London, University of Arizona Press, p. 171-190.

Williamson, J.H., and Wydoski, R.S., 1994, Genetics management guidelines: U.S. Fish and Wildlife Service, Denver, Colorado, 40 p.

Wydoski, R., and Mueller, G., 2004, The survival of razorback suckers released in the Colorado River between Davis and Parker Dams (Lake Havasu), 2004 annual progress report: Bureau of Reclamation, Denver, Colorado, 18 p.

Wydoski, R.S., and Wick, E.J., 1998, Ecological value of floodplain habitats to razorback suckers in the Upper Colorado River basin: Upper Colorado River Basin Recovery Program, U.S. Fish and Wildlife Service, Denver, Colorado, $55 \mathrm{p}$.

Wydoski, R.S., and Wiley, R.W., 1999, Management of undesirable fish, in Kohler, C.C., and Hubert, W.A., eds., Inland fisheries management in North America (2nd ed.): Bethesda, Maryland, American Fisheries Society, chapter 15, p. 403-430. 
83 Printed on recycled paper 